\title{
Recent Advances in the Interface Design of Solid-State Electrolytes for Solid-State Energy Storage Devices
}

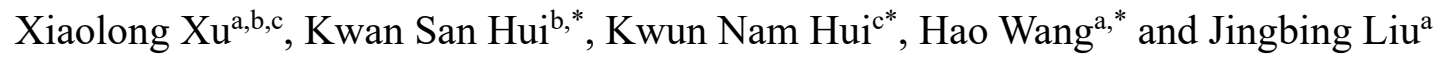

${ }^{a}$ The College of Materials Science and Engineering, Beijing University of Technology,

Beijing, People's Republic of China

${ }^{b}$ Engineering, Faculty of Science, University of East Anglia, Norwich, NR4 7TJ, United

Kingdom

${ }^{c} J o i n t$ Key Laboratory of the Ministry of Education, Institute of Applied Physics and Materials Engineering, University of Macau, Avenida da Universidade, Taipa, Macau SAR, China

*Corresponding author:

E-mail: k.hui@uea.ac.uk (Kwan San Hui)

E-mail: bizhui@umac.mo (Kwun Nam Hui)

E-mail: haowang@bjut.edu.cn (Hao Wang) 
Abstract: High-ion-conductivity solid-state electrolytes (SSEs) have been extensively explored for electrochemical energy storage technologies because these materials can enhance the safety of solid-state energy storage devices (SSESDs) and increase the energy density of these devices. In this review, an overview of SSEs based on their classification, including inorganic ceramics, organic solid polymers, and organic/inorganic hybrid materials, is outlined. Related challenges, such as low ionic conductivity, high interfacial resistance between electrodes and SSEs, poor wettability, and low thermal stability, are discussed. In particular, recent advances on properties of SSEs and interface design of high-performance SSESDs are highlighted. Several interface designs, including hybrid, interlayer, solid-liquid, quasi-solid-state gel, and in-situ solidification interface, between electrodes and SSEs for alleviating interfacial resistance, stability, and compatibility in SSESDs are comprehensively reviewed to provide insights into the future design directions of SSEs and SSESDs. The rational designs of various SSESDs for flexible and wearable devices, electronic devices, electric vehicles, and smart grid systems are proposed in accordance with different practical application requirements.

Keyword: Solid-state electrolyte; Solid-state energy storage device; Interface design; Application 


\section{Introduction}

Available commercial energy storage systems, such as lead acid batteries, nickel metal hydride batteries, and lithium-ion batteries, cannot satisfy the increasing energy demands of electronic devices, electric vehicles (EVs), and smart grid systems ${ }^{1-3}$. Combustible organic liquid electrolytes have been widely used in commercial lithiumion batteries, thereby offering the benefits of high conductivity and wetting of electrode surfaces for good electrochemical performance and long cycle life ${ }^{4-6}$. However, liquid electrolytes often suffer from inadequate electrochemical and thermal stabilities, low ion selectivity, poor safety, and even fire hazards during overcharge or abused operations $^{7}$. For these reasons, energy storage devices with high energy and power densities, long cycle life, and acceptable safety levels at an affordable cost should be developed. These problems may be effectively solved by replacing liquid electrolytes with solid-state electrolytes (SSEs) ${ }^{1}$.

As early as the 1830 s, Faraday discovered that heated $\mathrm{Ag}_{2} \mathrm{~S}$ and $\mathrm{PbF}_{2}$ show a remarkable conduction property, thereby leading to the research and development of SSEs $^{1}$. A variety of SSEs have been developed, and satisfactory results have been obtained in solid-state energy storage devices (SSESDs). Li et al. ${ }^{8}$ suggested that allsolid-state lithium-ion batteries in which flammable liquid electrolytes are replaced with SSEs are ultimate solutions for the safety issues of lithium-ion battery technologies, even under extreme conditions, such as high temperature or violent crush. Various research interests are directed toward the development of all-solid-state lithium-sulfur batteries because of the improvement of safety by using nonflammable inorganic SSEs ${ }^{9}$ 
${ }^{10}$. Research on SSEs has spread to whole energy storage field, including lithium-ion batteries $^{8,11}$, metal batteries ${ }^{12,13}$, and flexible energy storage devices ${ }^{14,15}$. With the development of SSEs, a series of review papers has been published. In 2017, Manthiram et al. ${ }^{1}$ studied lithium-ion battery chemistries and discussed major issues, such as achieving acceptable ionic conductivity, electrochemical stability, and mechanical properties of SSEs and compatible electrolyte/electrode interfaces. In 2018, Zhang et al. ${ }^{16}$ reviewed the mechanisms and properties of ion transport in inorganic SSEs and helped elucidate the ionic conductivity and stability of inorganic SSEs. However, a comprehensive review on references for SSE selections and interface design requirements for high-performance SSESDs for particular applications, including flexible and wearable devices, electronic devices, EVs, and smart grid systems, has yet to be conducted.

In this review, research significance and challenges of SSEs are presented. The selections and interface designs of SSEs are reviewed to provide insights into the development of SSEs and SSESDs (Fig. 1). The development of high-performance SSESDs for various applications is also proposed. 


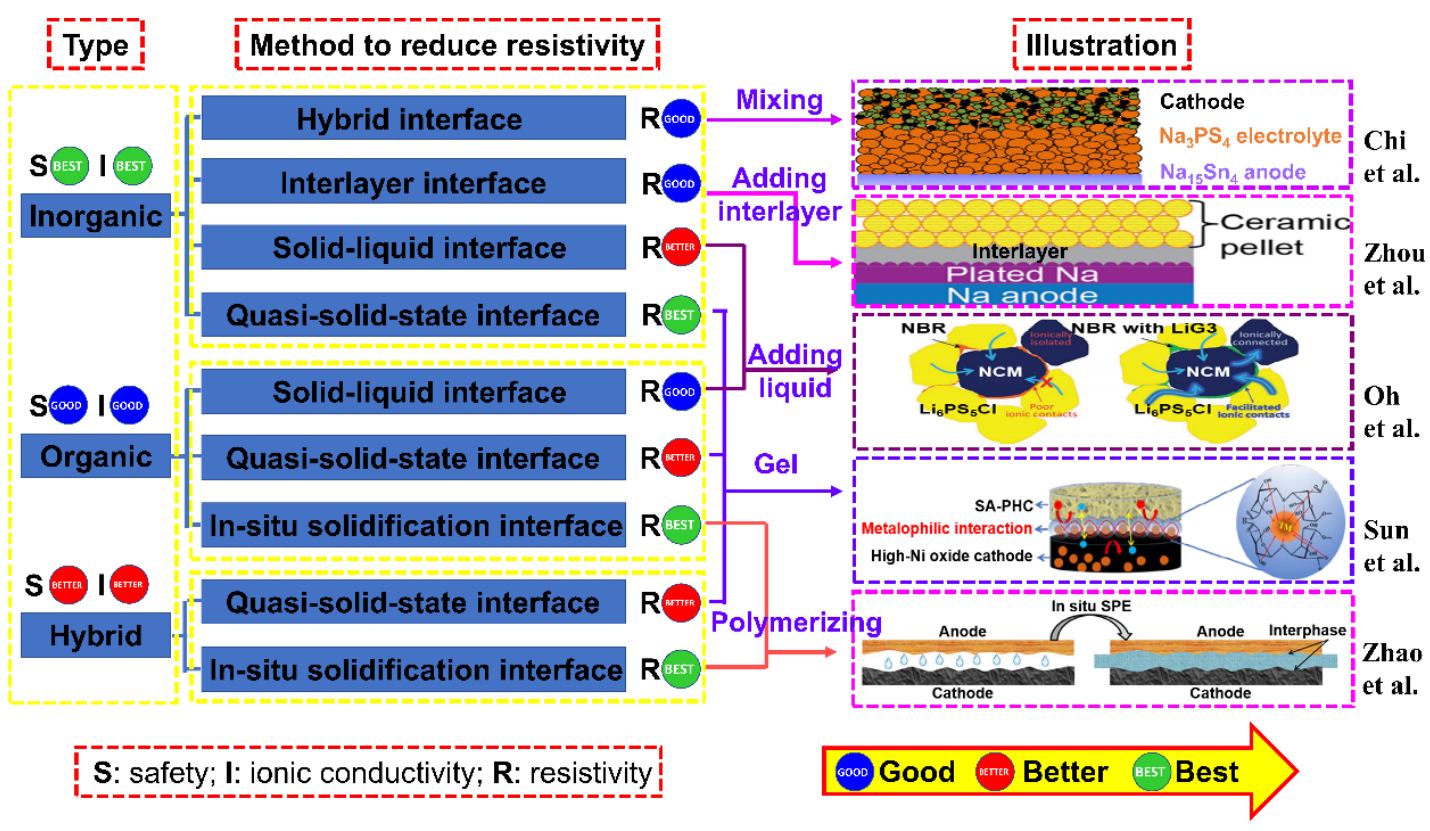

Fig. 1 Review scheme of potential research directions in solid-state electrolytes (SSEs), reported by Chi et al. ${ }^{17}$, Zhou et al. ${ }^{18}$, Oh et al. ${ }^{19}$, Sun et al. ${ }^{20}$ and Zhao et al..$^{21}$.

\section{Benefits of SSEs}

SSEs have two important roles in energy storage devices: (1) separating positive and negative electrodes to prevent internal short circuit and (2) providing a channel for ion transmission between electrodes during charge-discharge processes. The improvement of safety, suppression of metal dendrite, and fabrication of flexible and wearable devices can be achieved by replacing liquid electrolytes with SSEs.

\subsection{Safety improvement}

Safety is a vital requirement for all technologies and product applications. Liquid electrolytes offer high conductivity and good wetting for energy storage devices ${ }^{4-6}$. However, liquid electrolytes possess potential hazards, such as leakage, corrosiveness, and fire risks ${ }^{7}$, thereby threatening the safety of users and devices. 
Chi et al. ${ }^{17}$ prepared an inorganic SSE NaPS 4 for all-solid-state Na-ion batteries, thereby eliminating leakage problems and improving the thermal stability of devices. Zhang et al. ${ }^{22}$ utilized an organic SSE poly(propylene carbonate) to fabricate a solid polymer lithium-ion battery that can be charged and discharged at $120^{\circ} \mathrm{C}$. Zhu et al..$^{23}$ developed a hybrid $\mathrm{SSE} \mathrm{Li}_{0.33} \mathrm{La}_{0.557} \mathrm{TiO}_{3} /$ polyethylene oxide for a stable solid-state lithium-ion battery with an electrochemical stability window (up to $5.0 \mathrm{~V}$ vs. $\mathrm{Li} / \mathrm{Li}^{+}$). $\mathrm{Wu}$ et al. $^{24}$ used a quasi-SSE polyisobutylene in lithium-oxygen batteries, thereby preventing lithium corrosion by $\mathrm{H}_{2} \mathrm{O}$ crossover from cathodes (Fig. 2a). Batteries in a humid atmosphere display a charge potential of $3.4 \mathrm{~V}$ and a long cycle life of 150 cycles. Perea et al. ${ }^{25}$ showed that the high thermal stability of $\mathrm{Li}|\mathrm{SSE}| \mathrm{LiFePO}_{4}$ cells can be achieved using a solid polymer electrolyte (polyether with LiTFSI salt) compared with the same cell with a liquid electrolyte $(1 \mathrm{M} \mathrm{LiPF} 6$ in ethylene carbonate/diethyl carbonate). The thermal runaway (exothermic reaction) of charged Li|liquid electrolyte $\mid \mathrm{LiFePO} 4$ cells (Fig. 2b) starts at $90{ }^{\circ} \mathrm{C}$ with a self-heat rate of $3.2{ }^{\circ} \mathrm{C} \mathrm{min}^{-1}$ compared with that at $247^{\circ} \mathrm{C}\left(0.11^{\circ} \mathrm{C} \mathrm{min}-1\right)$ for $\mathrm{Li}|\mathrm{SSE}| \mathrm{LiFePO} 4$ cells (Fig. 2c). This result confirms that the thermal stability of $\mathrm{Li}|\mathrm{SSE}| \mathrm{LiFePO} 4$ cells improves. Therefore, replacing a liquid electrolyte with a SSE is an important strategy to improve the safety of energy storage devices. 
(a)
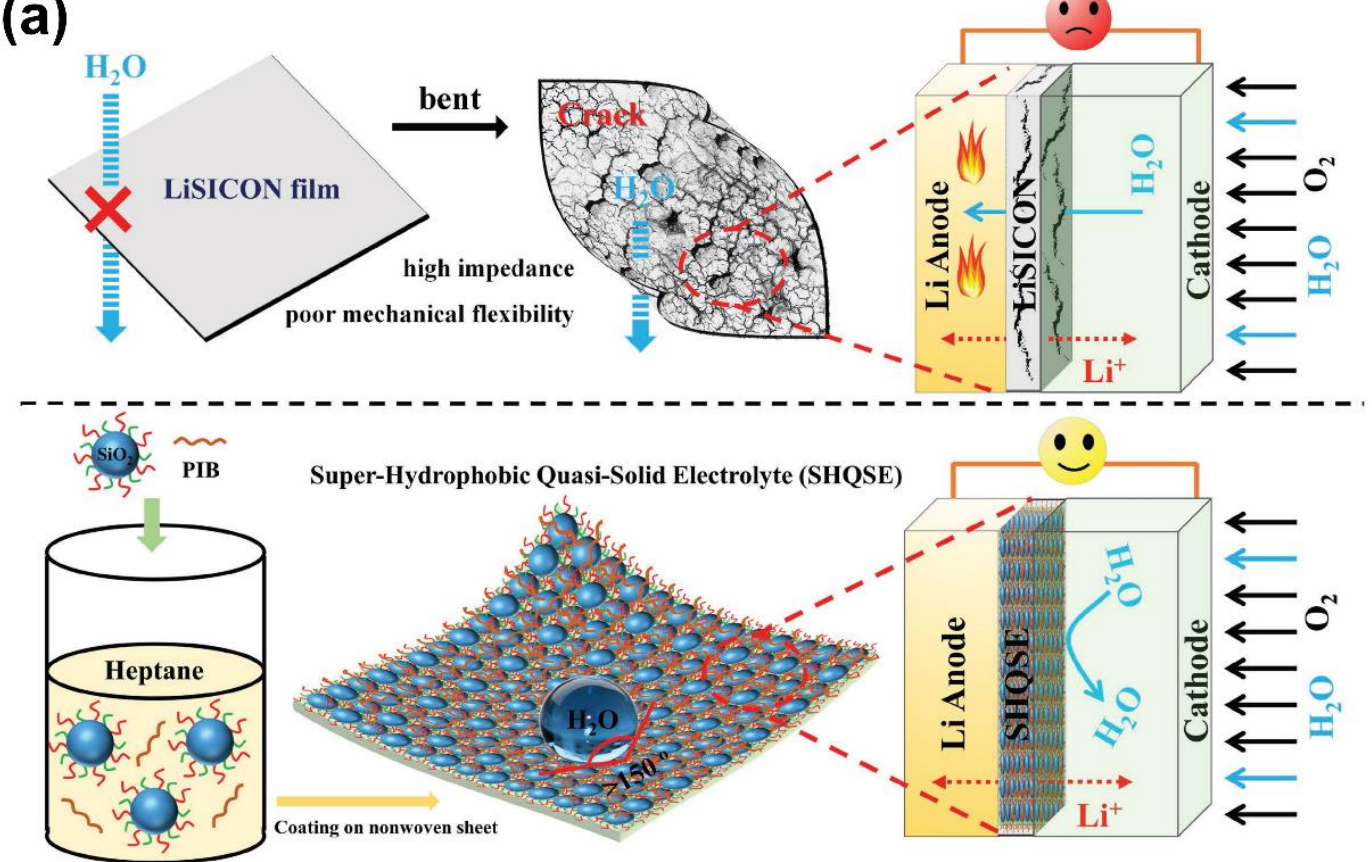

(b)

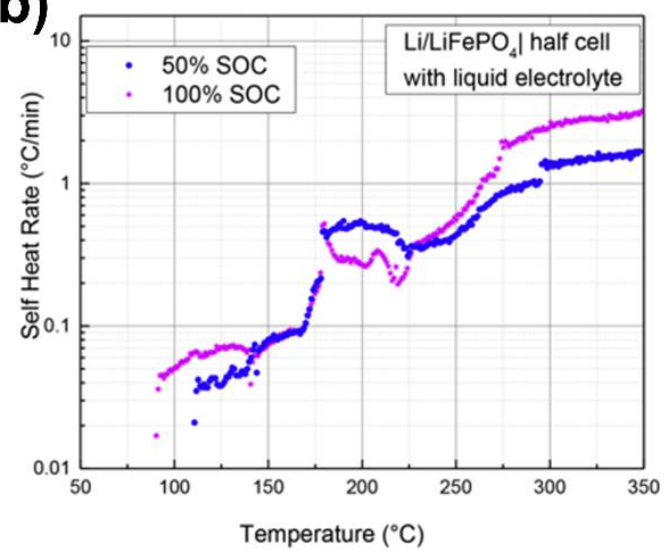

(c)

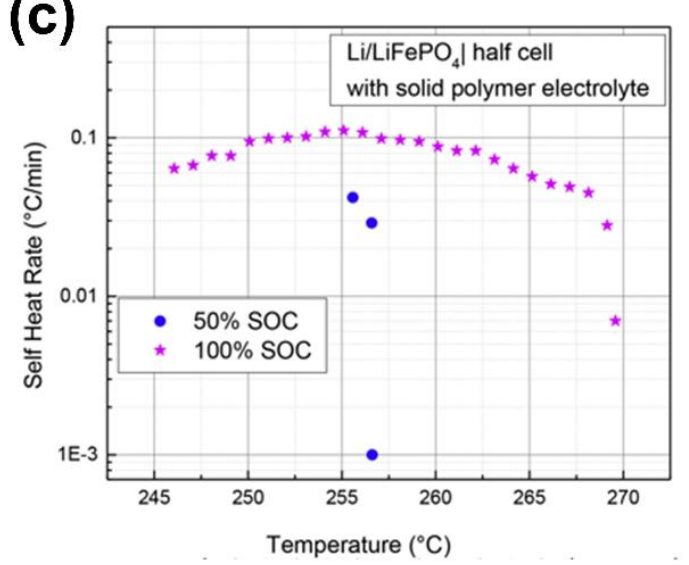

Fig. 2 (a) Schematic of the proposed solid lithium-oxygen battery in a humid atmosphere based on quasi-SSEs (reproduced from Ref. ${ }^{24}$, with permission from Wiley). Dependence of self-heating rate on the temperature of (b) Lilliquid electrolyte|LiFePO 4 and (c) $\mathrm{Li}|\mathrm{SSE}| \mathrm{LiFePO}_{4}$ cells (reproduced from Ref. ${ }^{25}$, with permission from Elsevier).

\subsection{Metal dendrite suppression}

Metal dendrite growths on metal anodes caused by unevenly distributed charges have seriously affected the Coulombic efficiency and safety of energy storage devices ${ }^{26}$. 
An inorganic SSE separator with good mechanical strength can avoid short circuit induced by the growth of metal dendrites piercing the separator in batteries ${ }^{27,28}$. Wang et al. ${ }^{29}$ used an inorganic SSE $\mathrm{Li}_{1.5} \mathrm{Al}_{0.5} \mathrm{Ge}_{1.5}\left(\mathrm{PO}_{4}\right)_{3}$ for a lithium-sulfur battery. An internal short circuit in batteries is effectively avoided because the good mechanical strength of $\mathrm{Li}_{1.5} \mathrm{Al}_{0.5} \mathrm{Ge}_{1.5}\left(\mathrm{PO}_{4}\right)_{3}$ is sufficient to prevent lithium dendrite piercing. $\operatorname{Han}^{30}$ and $\mathrm{Fu}$ et al. ${ }^{31}$ also demonstrated that inorganic SSEs can effectively suppress lithium dendrite formation by tuning the composition of a solid electrolyte interphase (SEI) to balance charge distribution because SSEs can control current distribution and lithium deposition.

In addition to inorganic SSEs, organic SSEs are effective routes for dendrite suppression. Yu et al. ${ }^{32}$ used a cellulose-based SSE with high nanopore and nanofiber concentrations in lithium sulfur batteries (Fig. 3a) and obtained a stable voltage plot of lithium plating/stripping for $200 \mathrm{~h}$ without dendrite growth (Fig. 3b). Lu et al. ${ }^{33}$ observed that lithium plating is preferentially concentrated in a thin SEI or defects to allow a high lithium ion flux in a liquid electrolyte (Fig. 3c), which triggers the growth of lithium dendrites. They designed a 3D network gel polymer electrolyte (3D-GPE: polyethylene oxide and polypropylene oxide) to effectively inhibit the growth of lithium dendrites in lithium metal batteries. This trait is attributed to a synergistic effect of the uniformity of SEIs and the high mechanical strength of the cross-linked structure of the 3D-GPE (Fig. 3d). This phenomenon results in an enhanced cycling stability of a Li|3D-GPE|LiFePO4 cell at $4 \mathrm{C}$ for 150 cycles (Fig. 3e). Li et al. ${ }^{34}$ reported a 3D fibernetwork-reinforced bicontinuous hybrid $\mathrm{SSE} \mathrm{Li}_{1.4} \mathrm{Al}_{0.4} \mathrm{Ti}_{1.6}\left(\mathrm{PO}_{4}\right)_{3} /$ polyacrylonitrile 
with a flexible lithium ion conductive network that helps suppress dendrite growth by mechanically reinforcing the fiber network (Fig. 3f). The obtained Li|SSE|Li cell shows long-term stability and safety at $0.3 \mathrm{~mA} \mathrm{~cm}^{-2}$ for $400 \mathrm{~h}$ (Fig. $3 \mathrm{~g}$ ).

However, recent studies indicated that lithium metal dendrites can pierce the SSEs (e.g. $\mathrm{Li}_{7} \mathrm{La}_{3} \mathrm{Zr}_{2} \mathrm{O}_{12}$ ) causing the short circuit of the cell ${ }^{35}$. Sudo et al. ${ }^{36}$ reported that the $\mathrm{Li}|\mathrm{SSE}| \mathrm{Li}$ cell with the $0.5 \mathrm{wt} \% \mathrm{Al}_{2} \mathrm{O}_{3}$-doped $\mathrm{Li}_{7} \mathrm{La}_{3} \mathrm{Zr}_{2} \mathrm{O}_{12}$ SSE showed a short circuit after $1000 \mathrm{~s}$ polarization at $0.5 \mathrm{~mA} \mathrm{~cm}^{-2}$. Such short circuit was due to lithium dendrite formation, which was evidenced by the surface morphology change of the SSE after polarization at $0.5 \mathrm{~mA} \mathrm{~cm}^{-2}$ for $0 \mathrm{~s} \mathrm{(Fig.} \mathrm{3h),} 280 \mathrm{~s}$ (Fig. 3i) and $840 \mathrm{~s}$ (Fig. 3j). Several black spots were observed after $280 \mathrm{~s}$ of polarization and the diameter of these black spots increased with polarization time $(840 \mathrm{~s})$, that are attributed to the lithium dendrite growth through the grain boundaries and voids in the SSE, suggesting that the lithium dendrite can pierce the SSEs. Therefore, the selection of suitable SSEs (such as inorganic SSEs with high ionic conductivity) is very important and the mechanical strength of SSEs needs to be further improved. 

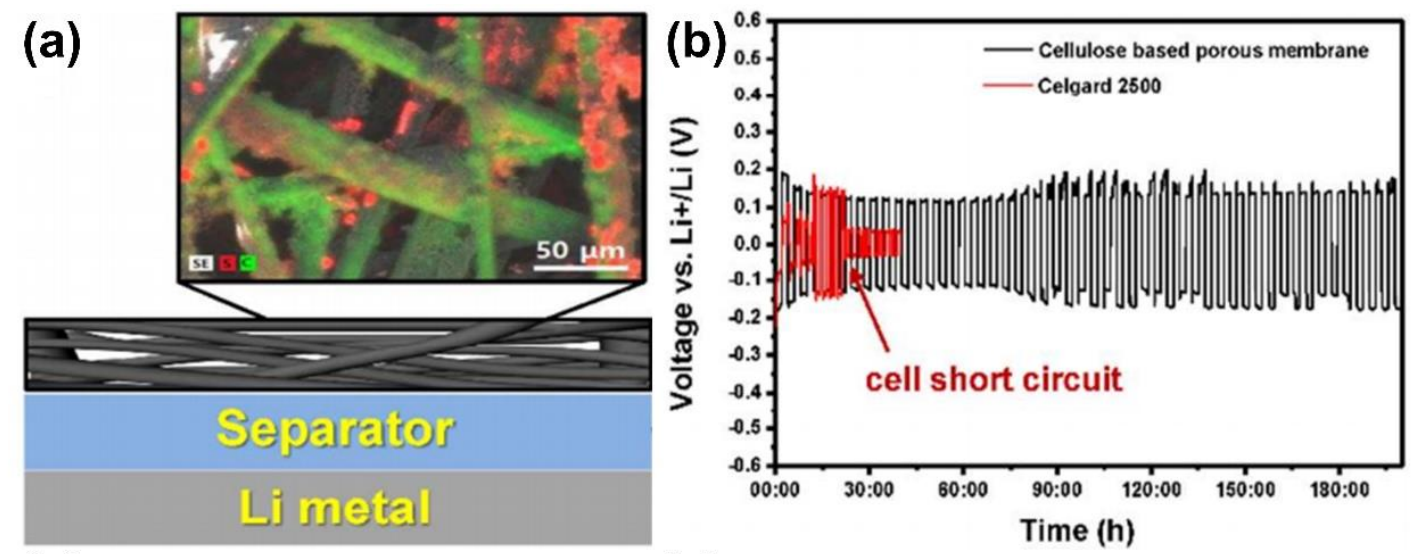

(c)
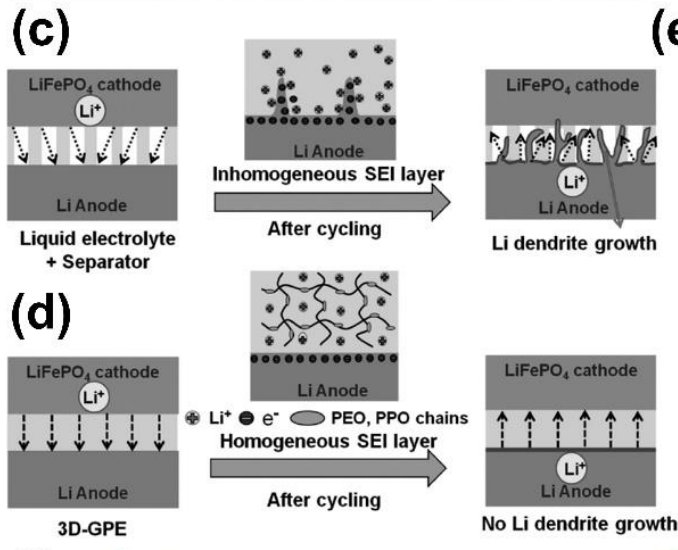

(e)

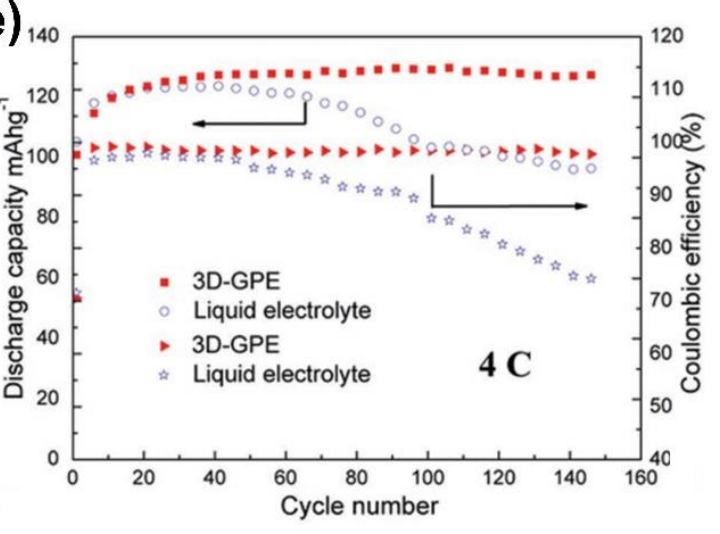

(f)
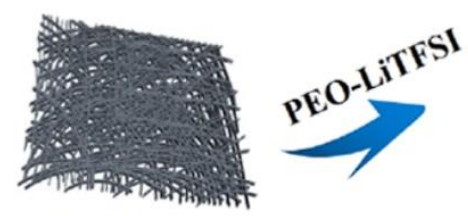

(g) LATP/PAN

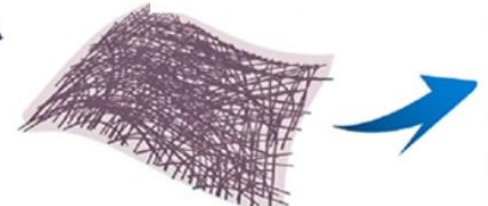

3D fiber-network reinforced

bicontinuous solid composite electrolyte (FCSE)
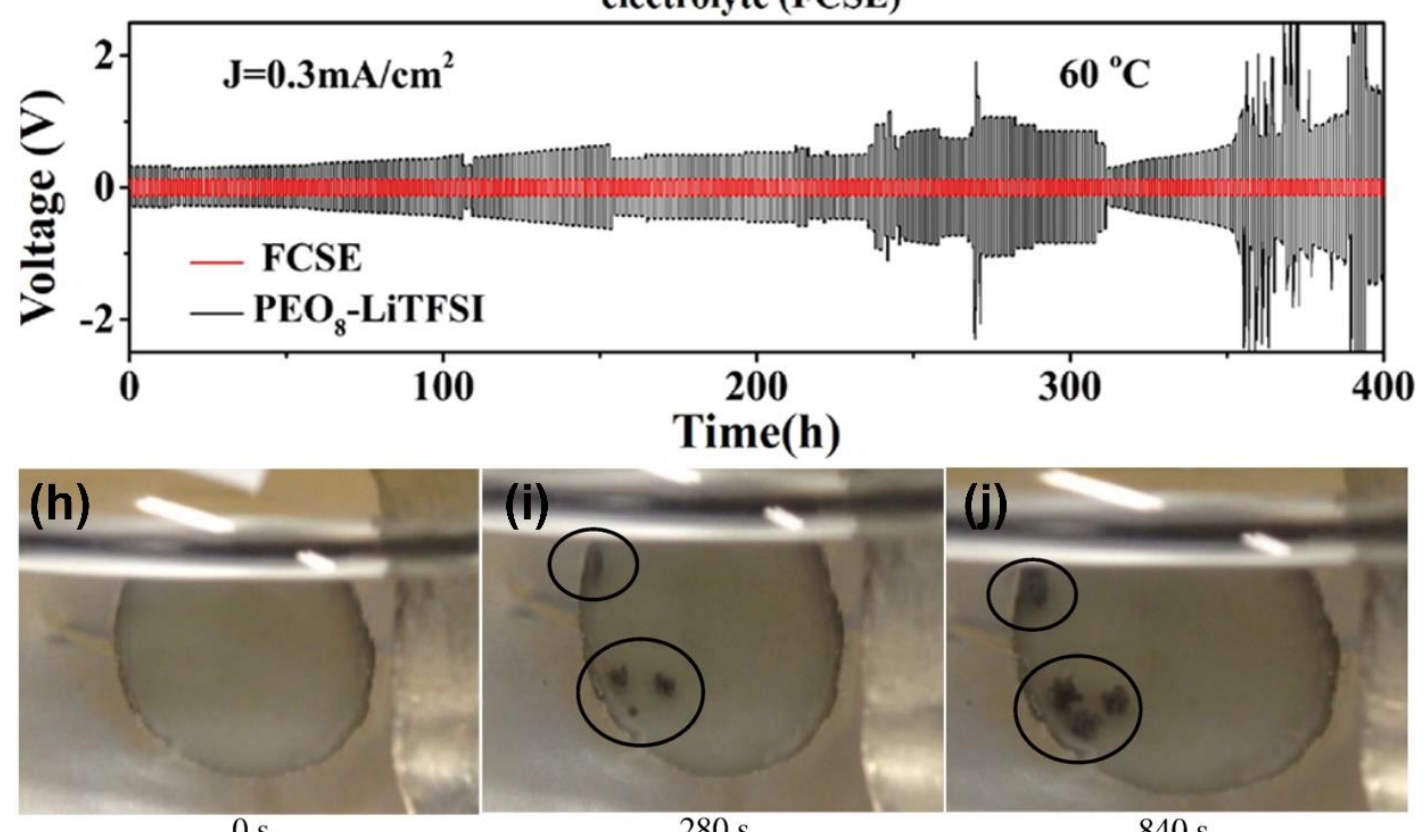

Fig. 3 (a) Configuration of a Li|SSE|sulfur cell with a cellulose-based porous membrane; 
upper graph, EDS mapping images of carbon paper/S cathode. (b) Voltage profiles of symmetric lithium cells with Celgard 2500 and cellulose-based porous membranes as separators at $2.4 \mathrm{~mA} \mathrm{~cm}^{-2}$ (reproduced from Ref. ${ }^{32}$, with permission from the American Chemical Society). Schematic of the changes in lithium electrodes with (c) a liquid electrolyte and (d) a 3D-GPE during lithium plating/stripping. (e) Cycling performance of $\mathrm{Li}|3 \mathrm{D}-\mathrm{GPE}| \mathrm{LiFePO}_{4}$ and $\mathrm{Li} \mid$ liquid electrolyte| $\mathrm{LiFePO}_{4}$ cells at $4 \mathrm{C}$ (reproduced from Ref. ${ }^{33}$, with permission from Wiley). (f) Schematic of the preparation of fiberreinforced membranes. (g) Voltage profiles of Li|SSE|Li and Li|PEO8-LiTFSI|Li cells for a lithium plating/stripping experiment at $0.3 \mathrm{~mA} \mathrm{~cm}^{-2}$ at $60{ }^{\circ} \mathrm{C}$ (reproduced from Ref. ${ }^{34}$, with permission from the American Chemical Society). The surface morphology change of $0.5 \mathrm{wt} \% \mathrm{Al}_{2} \mathrm{O}_{3}$-doped $\mathrm{Li}_{7} \mathrm{La}_{3} \mathrm{Zr}_{2} \mathrm{O}_{12} \mathrm{SSE}$ by polarization at $0.5 \mathrm{~mA} \mathrm{~cm}{ }^{-2}$ for (h) 0 , (i) 280 and (j) $840 \mathrm{~s}$ (reproduced from Ref. ${ }^{36}$, with permission from the Elsevier).

\subsection{Flexible and wearable device fabrication}

In daily life, no one can even imagine a world without portable/wearable electronic devices, including mobile phones, laptops, cameras, smartwatch, and activity trackers, which have considerably changed our lifestyles and brought significant convenience to people $^{37}$. Particularly, the emergence of flexible and wearable electronics has triggered continuous research on the development of reliable, flexible, and inexpensive SSEs, such as organic SSEs and hybrid SSEs, while inorganic SSEs were seldomly used in flexible and wearable device because of their higher hardness and brittleness.

Zhao et al. ${ }^{38}$ designed a flexible hydrogel SSE composed of bacterial cellulose 
microfibers and polyvinyl alcohol with an ionic conductivity of $80.8 \times 10^{-3} \mathrm{~S} \mathrm{~cm}^{-1}$ for flexible solid-state zinc-air batteries that are cycled well at any bending angle $(9$ cycles, for $40 \mathrm{~min}$ per cycle). Shu et al. $^{39}$ reported a flexible quasi-solid-state polymer electrolyte based on poly(vinylidene fluoride-co-hexafluoropropylene) for lithiumoxygen battery. Holes can be punched through flexible lithium-oxygen batteries that can even be cut into any desired shape, thereby demonstrating exceptional safety.

As illustrated in Fig. 4a, Li et al. ${ }^{40}$ designed a hierarchical polymer electrolyte (HPE, gelatin, and polyacrylamide) for safe and wearable solid-state zinc-ion battery with an areal energy density of $6.18 \mathrm{mWh} \mathrm{cm}^{-2}$, a power density of $148.2 \mathrm{~mW} \mathrm{~cm}^{-2}$, and a capacity of $\sim 120 \mathrm{mAh} \mathrm{g}^{-1}$, with a retention of $97 \%$ after 1000 cycles at $2772 \mathrm{~mA}$ $\mathrm{g}^{-1}$. Park et al. ${ }^{41}$ used a free standing gel electrolyte (gelatin) with an ionic conductivity of $3.1 \times 10^{-3} \mathrm{~S} \mathrm{~cm}^{-1}$ in an all-solid-state cable-type flexible zinc-air battery (Fig. $4 \mathrm{~b}$ ). They achieved a stable discharge at $0.1 \mathrm{~mA} \mathrm{~cm}^{-2}$ under external strain loaded on the battery every $20 \mathrm{~min}$ from the initial length of $7-3 \mathrm{~cm}$ (compression). Chen et al. ${ }^{42}$ used a polyacrylamide hydrogel as an electrolyte in a flexible solid-state zinc-ion hybrid supercapacitor that is flexible enough to sustain various deformations, including squeezing, twisting, and folding (Fig. 4c). Liu et al. ${ }^{43}$ used a gel-type SSE polyvinyl alcohol- $\mathrm{LiNO}_{3}$ in a flexible lithium-ion battery and demonstrated the flexibility to sustain various deformations, including bending, squeezing, twisting, and folding, because of its solid-state design. Flexible batteries can also be tailored into any desired shape and even be punched with holes, thereby exhibiting excellent safety (Fig. 4d). 


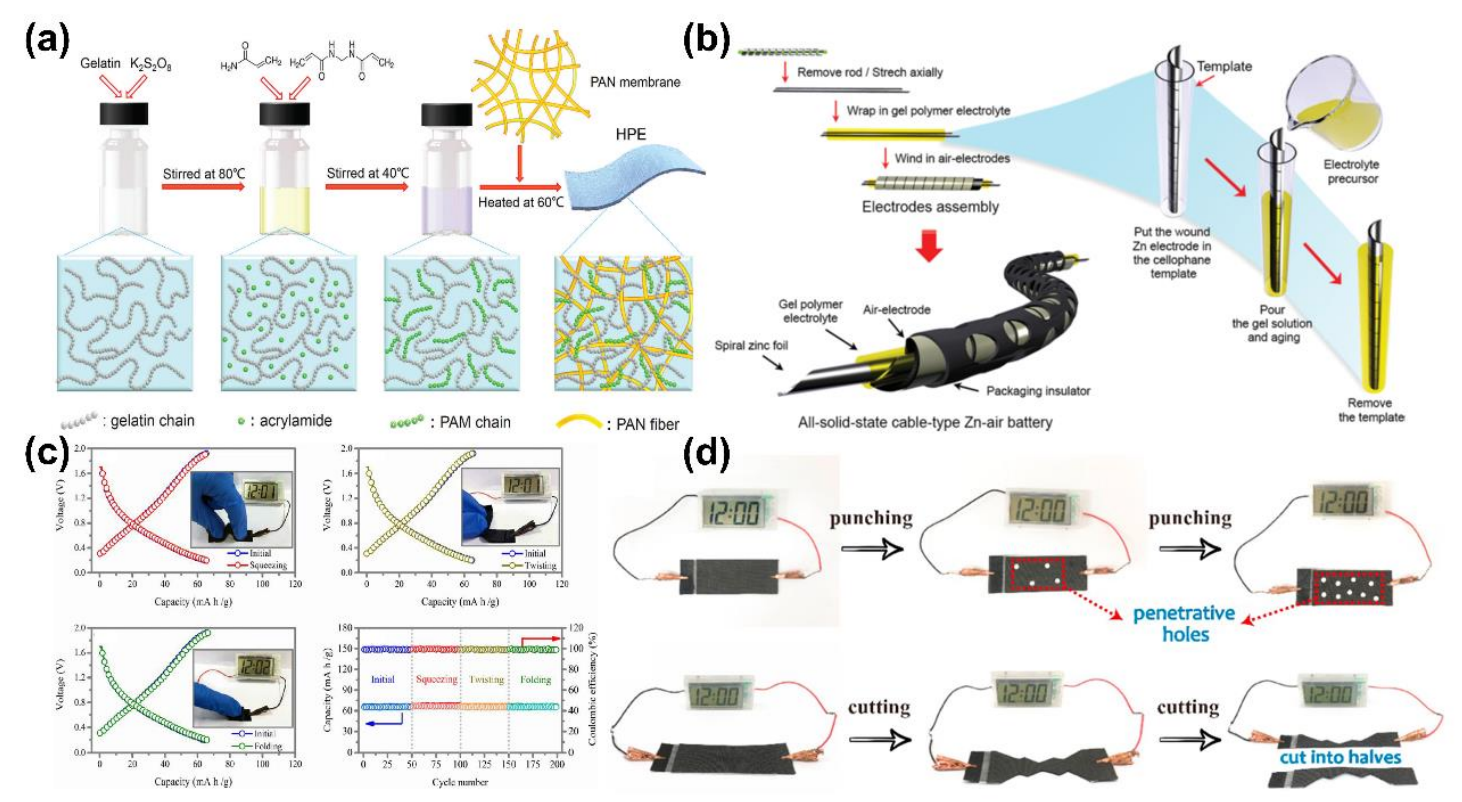

Fig. 4 (a) Schematic of the synthesis route of HPE (reproduced from Ref. ${ }^{40}$, with permission from the Royal Society of Chemistry). (b) Schematic of an all-solid-state cable-type flexible Zn-air battery assembly and the coating process of a gelatin-based gel polymer electrolyte on the surrounding spiral zinc anode (reproduced from Ref. ${ }^{41}$, with permission from Wiley). (c) Squeezing, twisting, folding, and powering an electronic watch under corresponding deformation conditions; cycling stability of a flexible solid-state zinc ion hybrid supercapacitor before and under various deformation conditions (reproduced from Ref. ${ }^{42}$, with permission from the Royal Society of Chemistry). (d) Drilling and cutting tests of the flexible lithium-ion battery (reproduced from Ref. ${ }^{43}$, with permission from Elsevier).

With the development of SSESDs, some SSE-related challenges, such as low ion conductivity and high interfacial resistance, have emerged as the main bottleneck restricting SSE applications at the current stage. 


\section{Challenges}

A good electrochemical energy storage device needs an external circuit with good electronic conductivity and an internal circuit with good ionic conductivity ${ }^{44,45}$. Good electronic conductivity is primarily dependent on the electrode design of an energy storage device ${ }^{2,5,6,46}$, but this trait is not discussed here. Ionic conductivity is primarily dependent on the ionic conductivity of electrolytes and the interfacial resistance between electrolytes and electrodes in devices ${ }^{47,48}$ that can affect the electrochemical performance of SSESDs (Fig. 5) ${ }^{49}, 50$. The discharge specific capacity, high $\mathrm{C}$ rate performance, and power density of SSESDs are greatly reduced by the sluggish kinetics of ion transport ${ }^{51-53}$. A high-performance energy storage device requires a balance between electron and ion transport. A poor ion transport exacerbates the electrochemical performance of devices and reduces their energy efficiency ${ }^{54,55}$. Any imbalance in electron and ion transport can lead to the non-uniformly distributed charge on the surface of electrodes, resulting in a series of side reactions, especially dendrite growth, on the surface of metal electrodes ${ }^{2,26,56}$. Poor interfacial contact between the electrolyte and electrodes increase the interfacial resistance, thereby reducing the bulk energy density of the device ${ }^{57,58,59,60,61}$. Finding suitable SSEs and reducing interfacial resistance are important for the development of high-performance SSESDs. 


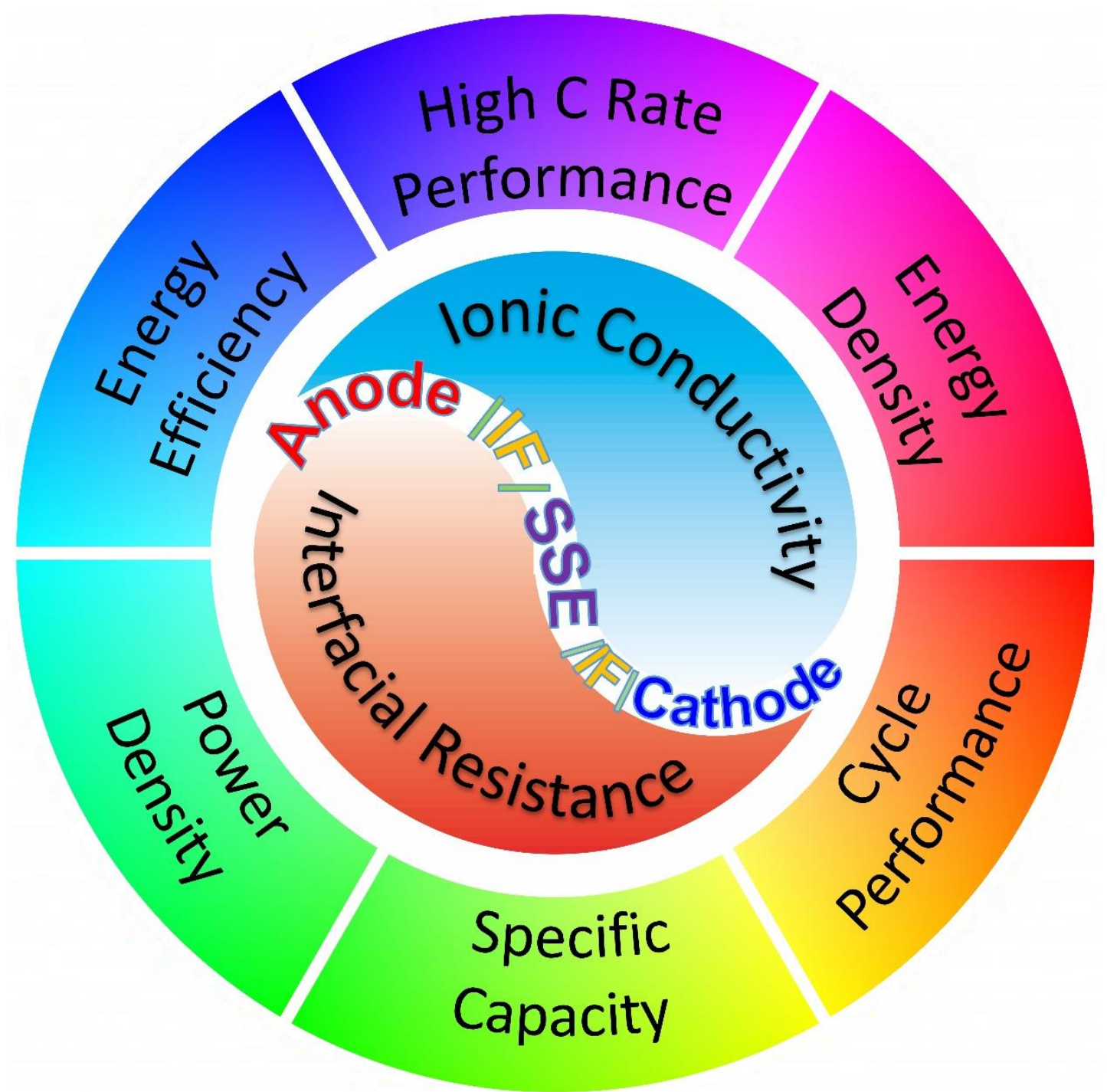

Fig. 5 SSE-related challenges in studies on low ionic conductivity and high interfacial resistance. SSE, solid-state electrolyte; IF, interface.

\section{Properties of SSEs}

SSEs with high ionic conductivity is crucial for the practical applications of SSESDs. The ionic conductivities and electrochemical window of different SSEs are presented in Table 1. Moreover, the features including low cost processing, mechanical property, air stability, electronic insulation, ion conductivity, thermal stability, chemical stability and electrochemical stability for inorganic, organic and hybrid SSEs are 
compared in Fig. 6.

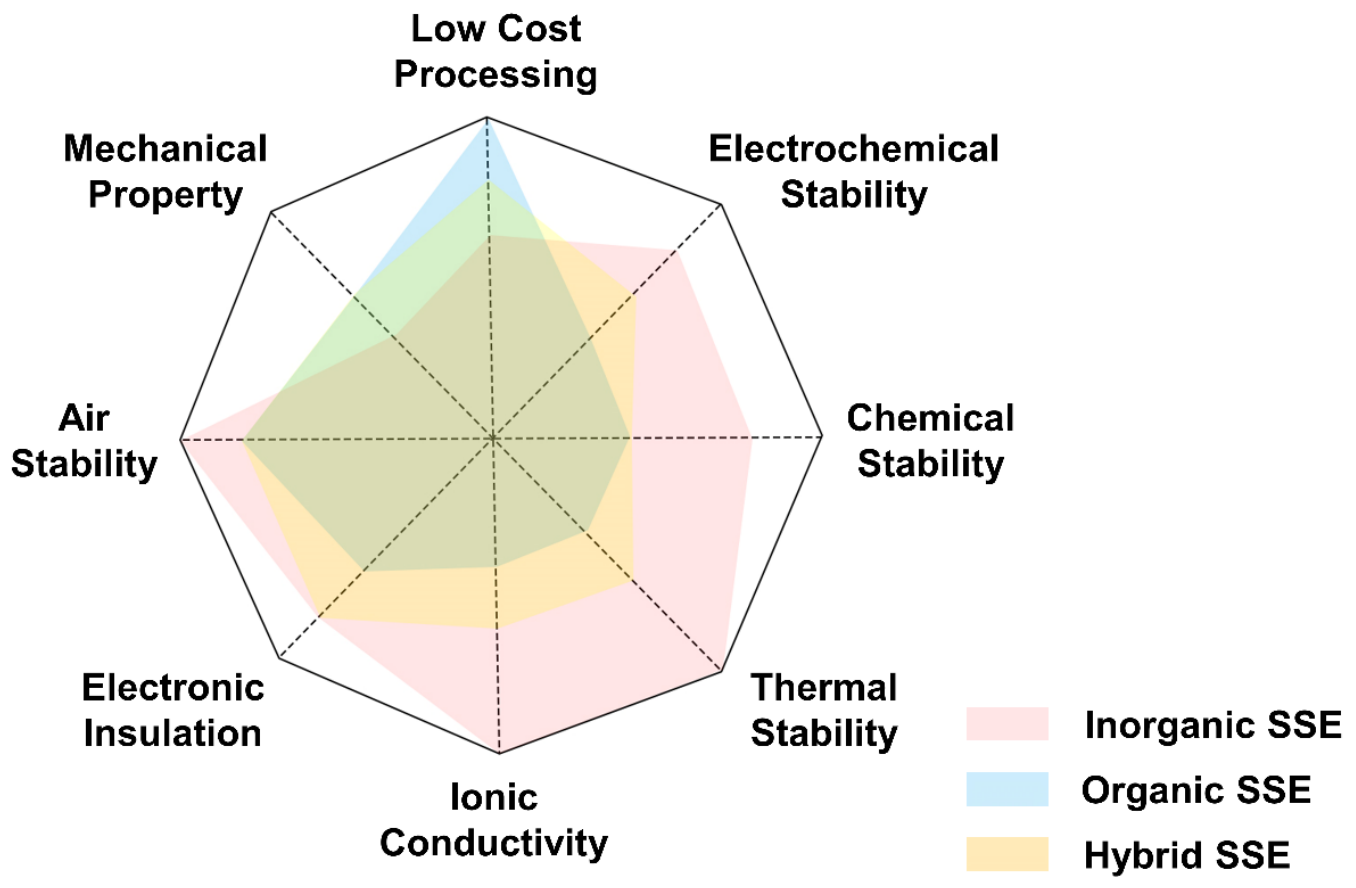

Fig. 6 The feature comparison of inorganic, organic and hybrid SSEs. 
Table 1 Comparison of ion conductivity and electrochemical window of different solid-state electroyltes.

\begin{tabular}{|c|c|c|c|c|c|c|}
\hline \multicolumn{3}{|c|}{ SSE classification } & SSE composition & Ionic conductivity $\left(\mathrm{S} \mathrm{cm}^{-1}\right)$ & Electrochemical & Ref. \\
\hline \multirow{27}{*}{$\begin{array}{c}\text { Inorganic } \\
\text { SSEs }\end{array}$} & \multirow{6}{*}{\multicolumn{2}{|c|}{ Garnet-type }} & $\mathrm{Li}_{7} \mathrm{La}_{3} \mathrm{Zr}_{2} \mathrm{O}_{12}$ & $1.63 \times 10^{-6}(300 \mathrm{~K})$ & - & 62 \\
\hline & & & $\mathrm{Li}_{6.5} \mathrm{La}_{2.5} \mathrm{Sr}_{0.5} \mathrm{TaZrO}_{12}$ & $3.08 \times 10^{-4}(293.16 \mathrm{~K})$ & - & 63 \\
\hline & & & $\mathrm{Li}_{5.9} \mathrm{Al}_{0.2} \mathrm{La}_{3} \mathrm{Zr}_{1.75} \mathrm{~W}_{0.25} \mathrm{O}_{12}$ & $5.20 \times 10^{-4}(298.16 \mathrm{~K})$ & - & 64 \\
\hline & & & $\mathrm{Li}_{7.06} \mathrm{La}_{3} \mathrm{Zr}_{1.94} \mathrm{Y}_{0.06} \mathrm{O}_{12}$ & $9.56 \times 10^{-4}(298.16 \mathrm{~K})$ & - & 65 \\
\hline & & & $\mathrm{Li}_{6.5} \mathrm{La}_{3} \mathrm{Zr}_{1.75} \mathrm{Te}_{0.25} \mathrm{O}_{12}$ & $1.02 \times 10^{-3}(303.16 \mathrm{~K})$ & - & 66 \\
\hline & & & $\mathrm{Li}_{6.55} \mathrm{La}_{3} \mathrm{Zr}_{2} \mathrm{Ga}_{0.15 \sim 0.3} \mathrm{O}_{12}$ & $1.30 \times 10^{-3}(297.16 \mathrm{~K})$ & - & 67 \\
\hline & \multirow{7}{*}{$\begin{array}{l}\text { Pervoskite- } \\
\text { type }\end{array}$} & \multirow{5}{*}{$\begin{array}{l}\text { Lithium- } \\
\text { ion }\end{array}$} & $\mathrm{Li}_{3} \mathrm{OX}(\mathrm{X}=\mathrm{Cl}, \mathrm{Br})$ & $1.00 \times 10^{-6}(298.16 \mathrm{~K})$ & - & 68 \\
\hline & & & $\mathrm{Li}_{0.43} \mathrm{La}_{0.56} \mathrm{Ti}_{0.95} \mathrm{Ge}_{0.05} \mathrm{O}_{3}$ & $1.20 \times 10^{-5}(298.16 \mathrm{~K})$ & $0-10$ & 69 \\
\hline & & & $\mathrm{Li}_{0.38} \mathrm{Sr}_{0.44} \mathrm{Ta}_{0.7} \mathrm{Hf}_{0.3} \mathrm{O}_{2.95} \mathrm{~F}_{0.05}$ & $4.80 \times 10^{-4}(298.16 \mathrm{~K})$ & $2.5-5$ & 70 \\
\hline & & & $\mathrm{Li}_{0.29} \mathrm{La}_{0.57} \mathrm{TiO}_{3}$ & $1.60 \times 10^{-3}(300 \mathrm{~K})$ & - & 71 \\
\hline & & & $\mathrm{Li}_{3} \mathrm{OCl}_{0.5} \mathrm{Br}_{0.5}$ & $1.94 \times 10^{-3}(298.16 \mathrm{~K})$ & - & 72 \\
\hline & & \multirow{2}{*}{$\begin{array}{l}\text { Sodium- } \\
\text { ion }\end{array}$} & $\mathrm{Na}_{1.5} \mathrm{La}_{1.5} \mathrm{TeO}_{6}$ & $1.00 \times 10^{-8}(298.16 \mathrm{~K})$ & - & 73 \\
\hline & & & $\mathrm{Na}_{1 / 3} \mathrm{La}_{1 / 3} \mathrm{Sr}_{1 / 3} \mathrm{ZrO}_{3}$ & $1.025 \times 10^{-5}(298.16 \mathrm{~K})$ & - & 74 \\
\hline & \multirow{11}{*}{$\begin{array}{l}\text { Argyrodite- } \\
\text { type } \\
\text { (LISICON) }\end{array}$} & \multirow{7}{*}{$\begin{array}{l}\text { Lithium- } \\
\text { ion }\end{array}$} & $\mathrm{Li}_{4} \mathrm{SnS}_{4}$ & $1.10 \times 10^{-4}(298.16 \mathrm{~K})$ & - & 75 \\
\hline & & & Li-B-H & $2.70 \times 10^{-4}(308.16 \mathrm{~K})$ & $-0.2-5$ & 76 \\
\hline & & & $\mathrm{Li}_{6} \mathrm{PS}_{5} \mathrm{Cl}$ & $1.80 \times 10^{-3}(298.16 \mathrm{~K})$ & $-0.5-5$ & 77 \\
\hline & & & $\mathrm{Li}_{6-\mathrm{y}} \mathrm{PS}_{5-\mathrm{y}} \mathrm{Cl}_{1+\mathrm{y}}(\mathrm{y}=0-0.5)$ & $3.90 \times 10^{-3}(298.16 \mathrm{~K})$ & $0-3$ & 78 \\
\hline & & & $\mathrm{Li}_{6} \mathrm{PS}_{5} \mathrm{Cl}$ & $4.96 \times 10^{-3}(299.36 \mathrm{~K})$ & $0-4.5$ & 79 \\
\hline & & & $\mathrm{Li}_{10} \mathrm{GeP}_{2} \mathrm{~S}_{12}$ & $12.0 \times 10^{-3}(300.16 \mathrm{~K})$ & $-0.5-5$ & 80 \\
\hline & & & $\mathrm{Li}_{6+\mathrm{x}} \mathrm{P}_{1-\mathrm{x}} \mathrm{Ge}_{\mathrm{x}} \mathrm{S}_{5} \mathrm{I}$ & $18.4 \times 10^{-3}(298.16 \mathrm{~K})$ & $0-2.75$ & 81 \\
\hline & & \multirow{4}{*}{$\begin{array}{l}\text { Sodium- } \\
\text { ion }\end{array}$} & $\mathrm{Na}_{11} \mathrm{Sn}_{2} \mathrm{PS}_{12}$ & $1.40 \times 10^{-4}(298.16 \mathrm{~K})$ & - & 82 \\
\hline & & & $\mathrm{Na}_{11} \mathrm{Sn}_{2} \mathrm{SbS}_{12}$ & $5.60 \times 10^{-4}(298.16 \mathrm{~K})$ & - & 83 \\
\hline & & & $\mathrm{Na}_{10.8} \mathrm{Sn}_{1.9} \mathrm{PS}_{11.8}$ & $6.70 \times 10^{-4}(298.16 \mathrm{~K})$ & $-0.5-5$ & 84 \\
\hline & & & $\mathrm{Na}_{11} \mathrm{Sn}_{2} \mathrm{PS}_{12}$ & $4.00 \times 10^{-3}(298.16 \mathrm{~K})$ & - & 85 \\
\hline & \multirow{3}{*}{$\begin{array}{l}\text { Phosphate- } \\
\text { type } \\
\text { (NASICON) }\end{array}$} & \multirow{3}{*}{$\begin{array}{l}\text { Lithium- } \\
\text { ion }\end{array}$} & $\mathrm{LiTi}_{2}\left(\mathrm{PO}_{4}\right)_{3}$ & $2.10 \times 10^{-5}(298.16 \mathrm{~K})$ & - & 86 \\
\hline & & & $\mathrm{Li}_{1.1} \mathrm{Zr}_{1.9} \mathrm{La}_{0.1}\left(\mathrm{PO}_{4}\right)_{3}$ & $7.20 \times 10^{-5}(298.16 \mathrm{~K})$ & $-0.5-5$ & 87 \\
\hline & & & $\mathrm{Li}_{1.3} \mathrm{Al}_{0.3} \mathrm{Ti}_{1.7}\left(\mathrm{PO}_{4}\right)_{3}$ & $4.20 \times 10^{-4}(298.16 \mathrm{~K})$ & - & 88 \\
\hline
\end{tabular}




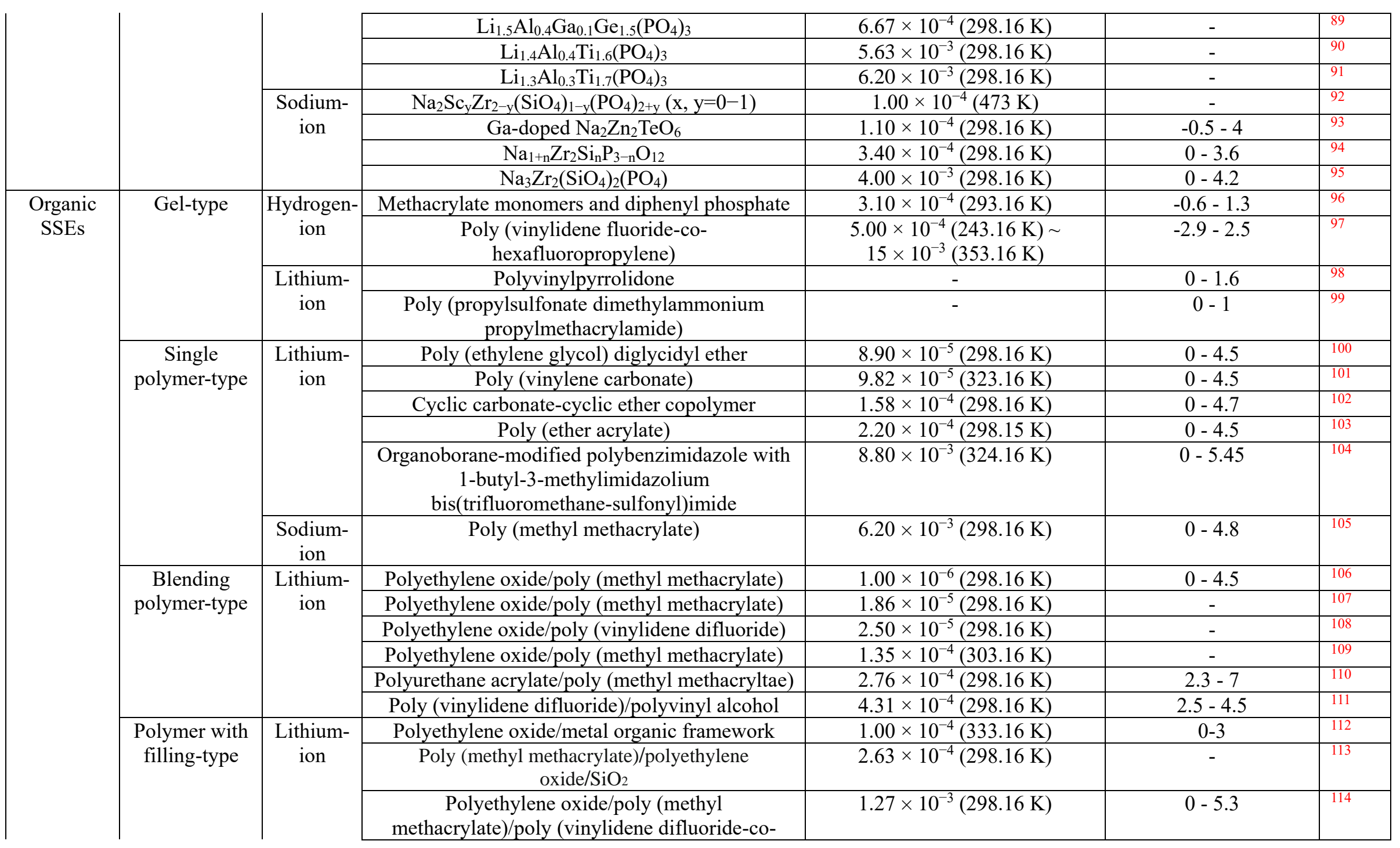




\begin{tabular}{|c|c|c|c|c|c|}
\hline & & hexafluoropropylene)/SiO 2 & & & \\
\hline & Zinc-ion & $\begin{array}{l}\text { Poly (vinylidene difluoride-co- } \\
\text { hexafluoropropylene) } / \mathrm{CeO}_{2}\end{array}$ & $1.50 \times 10^{-5}(298.16 \mathrm{~K})$ & $0-2.7$ & 115 \\
\hline \multirow[t]{10}{*}{ Hybrid SSEs } & & $\mathrm{Li}_{10} \mathrm{GeP}_{2} \mathrm{~S}_{12} /$ polyethylene oxide & $1.18 \times 10^{-5}(298.16 \mathrm{~K})$ & $0-5.7$ & 116 \\
\hline & & $\mathrm{Li}_{6.4} \mathrm{La}_{3} \mathrm{Zr}_{1.4} \mathrm{Ta}_{0.6} \mathrm{O}_{12} /$ polyethylene oxide & $1.00 \times 10^{-4}(328.16 \mathrm{~K})$ & $0-5$ & 117 \\
\hline & & $\mathrm{Li}_{6.4} \mathrm{La}_{3} \mathrm{Zr}_{1.4} \mathrm{Ta}_{0.6} \mathrm{O}_{12} /$ polyethylene oxide & $1.60 \times 10^{-4}(303.16 \mathrm{~K})$ & $0-5.03$ & 118 \\
\hline & & $\mathrm{Li}_{1.5} \mathrm{Al}_{0.5} \mathrm{Ge}_{1.5}\left(\mathrm{PO}_{4}\right)_{3} /$ polyethylene oxide & $1.67 \times 10^{-4}(298.16 \mathrm{~K})$ & $0-4.5$ & 119 \\
\hline & & $\mathrm{Li}_{0.33} \mathrm{La}_{0.557} \mathrm{TiO}_{3} /$ polyethylene oxide & $2.40 \times 10^{-4}(298.16 \mathrm{~K})$ & $0-5$ & 23 \\
\hline & & $\mathrm{Li}_{6.5} \mathrm{La}_{3} \mathrm{Zr}_{1.5} \mathrm{Nb}_{0.5} \mathrm{O}_{12} /$ polyethylene oxide & $3.60 \times 10^{-4}(298.16 \mathrm{~K})$ & $0-4.3$ & 120 \\
\hline & & $\begin{array}{l}\mathrm{Li}_{7} \mathrm{La}_{3} \mathrm{Zr}_{2} \mathrm{O}_{12} / \text { in poly(vinylidene fluoride-co- } \\
\text { hexafluoropropylene) }\end{array}$ & $3.71 \times 10^{-4}(303.16 \mathrm{~K})$ & $0-4.65$ & 121 \\
\hline & & $\mathrm{Li}_{6} \mathrm{PS}_{5} \mathrm{Cl} /$ polyethylene oxide & $1.00 \times 10^{-3}(298.16 \mathrm{~K})$ & $0-4$ & 122 \\
\hline & & $\mathrm{Li}_{7} \mathrm{La}_{3} \mathrm{Zr}_{2} \mathrm{O}_{12} /$ polyethylene oxide & $1.04 \times 10^{-3}(333.16 \mathrm{~K})$ & $0-4.2$ & 123 \\
\hline & & $\mathrm{Li}_{10} \mathrm{GeP}_{2} \mathrm{~S}_{12} /$ polyethylene oxide & $1.21 \times 10^{-3}(353.16 \mathrm{~K})$ & $0-5.7$ & 116 \\
\hline
\end{tabular}


4.1 Inorganic SSEs, including garnet, perovskite, argyrodite, and phosphate types

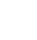

Typically, inorganic SSEs, which are a kind of ion conductors, rely on the concentration and distribution of defects ${ }^{124,125}$. Ionic transport in inorganic SSEs starts when ions at local sites become excited to neighboring sites and collectively diffuse on a macroscopic scale ${ }^{126}$. Some materials with a crystalline framework composed of immobile ions and a sublattice of mobile species can achieve high ionic conductivities without a high defect concentration ${ }^{127-130}$. Three primary criteria must be fulfilled to achieve fast ionic conduction in inorganic $\operatorname{SSEs}^{1}$ : (1) the number of equivalent (or nearly equivalent) sites available for mobile ions to occupy should be much larger than the number of mobile species; (2) the migration barrier energies between adjacent available sites should be low enough for an ion to hop easily from one site to another; and (3) these available sites must be connected to form a continuous diffusion pathway.

\subsubsection{Garnet-type SSEs}

Garnet-type SSEs have been widely explored because of their high ionic conductivity of $1 \times 10^{-3} \mathrm{~S} \mathrm{~cm}^{-1}$, environmental stability, and electrochemical stability window of 0-9 $\mathrm{V}^{131-133}$. These SSEs are a kind of lithium transition metal oxides, whose lithium ion transport relies on their lattice defects, and element doping is beneficial to the improvement of lithium ionic conductivity. Awaka et al. ${ }^{62}$ synthesized a garnet-type SSE $\mathrm{Li}_{7} \mathrm{La}_{3} \mathrm{Zr}_{2} \mathrm{O}_{12}$ with tetragonal symmetry ( $\mathrm{I}_{1} / \mathrm{acd}$, no.142) via a flux method. Tetragonal $\mathrm{Li}_{7} \mathrm{La}_{3} \mathrm{Zr}_{2} \mathrm{O}_{12}$ has lattice constants of $\mathrm{a}=13.134(4) \AA$ and $\mathrm{c}=12.663(8) \AA$ and fully ordered arrangement of lithium atoms (Fig. 7a), thereby delivering a lithium ionic 
1 conductivity of $1.63 \times 10^{-6} \mathrm{~S} \mathrm{~cm}^{-1}$ at $26.85{ }^{\circ} \mathrm{C}$ (Fig. $7 \mathrm{~b}$ ). To improve the ionic

2 conductivity, Kammampata et al. $^{63}$ prepared some garnet-type SSEs

$3 \quad \mathrm{Li}_{6.5} \mathrm{La}_{2.5} \mathrm{~A}_{0.5} \mathrm{TaZrO}_{12} \quad(\mathrm{~A}=\mathrm{Ca}, \quad \mathrm{Sr}, \mathrm{Ba})$ and found that $\mathrm{Sr}$-doped garnet-type

$4 \quad \mathrm{Li}_{6.5} \mathrm{La}_{2.5} \mathrm{Sr}_{0.5} \mathrm{TaZrO}_{12}$ shows the highest lithium ion conductivity of $3.08 \times 10^{-4} \mathrm{~S} \mathrm{~cm}^{-1}$

5 (Fig. 7c). Shao et al. ${ }^{64}$ developed garnet-type $\mathrm{SSE} \mathrm{Li}_{5.9} \mathrm{Al}_{0.2} \mathrm{La}_{3} \mathrm{Zr}_{1.75} \mathrm{~W}_{0.25} \mathrm{O}_{12}$ whose Li

6 (24d) and $\mathrm{Zr}$ (16a) sites are doped with $\mathrm{Al}$ and $\mathrm{W}$, and the lithium ion transport route is

7 24d-96h-48g-96h-24d, leading to an ionic conductivity of $5.2 \times 10^{-4} \mathrm{~S} \mathrm{~cm}^{-1}$ (Fig. $7 \mathrm{~d}$ ).

$8 \mathrm{Al}$ and W co-doping significantly leads to an improved ionic conductivity of $5.2 \times 10^{-4}$

$9 \mathrm{~S} \mathrm{~cm}^{-1}$ at room temperature (Fig. 7e). Fig. $7 \mathrm{f}$ displays a polished ceramic pellet and reveals the morphological characteristics of the local environment and a surface 11 roughness of $\sim 500 \mathrm{~nm}$. partial substitution of trivalent $\mathrm{Y}$ for a tetravalent $\mathrm{Zr}$. A small amount (3 at $\%$ ) of $\mathrm{Y}$ for

$14 \mathrm{Zr}$ helps increase the ionic conductivity to $9.56 \times 10^{-4} \mathrm{~S} \mathrm{~cm}^{-1}$ at $25^{\circ} \mathrm{C}$. Deviannapoorani 
1 regulation of their crystal defects and reaches its limit ${ }^{134-136}$. Pfenninger et al. ${ }^{137}$ used a

2 garnet-type $\mathrm{SSE} \mathrm{Li}_{6.25} \mathrm{Al}_{0.25} \mathrm{La}_{3} \mathrm{Zr}_{2} \mathrm{O}_{12}$ in $\mathrm{Li}_{4} \mathrm{Ti}_{5} \mathrm{O}_{12}|\mathrm{SSE}| \mathrm{Li}$ cells and obtained a capacity

3 of $\sim 175 \mathrm{mAh} \mathrm{g}^{-1}$ with a capacity retention of $90 \%$ at $2.5 \mathrm{~mA} \mathrm{~g}^{-1}$ after 22 cycles.

4 However, to date, the development of high-performance SSESDs with garnet-type

5 SSEs has minimal success because of the high solid-solid interfacial resistance between

6 garnet-type SSEs and electrode materials ${ }^{138,}$ 139, 129. Future garnet-type SSE

7 development will focus on interfacial designs between SSEs and electrodes.
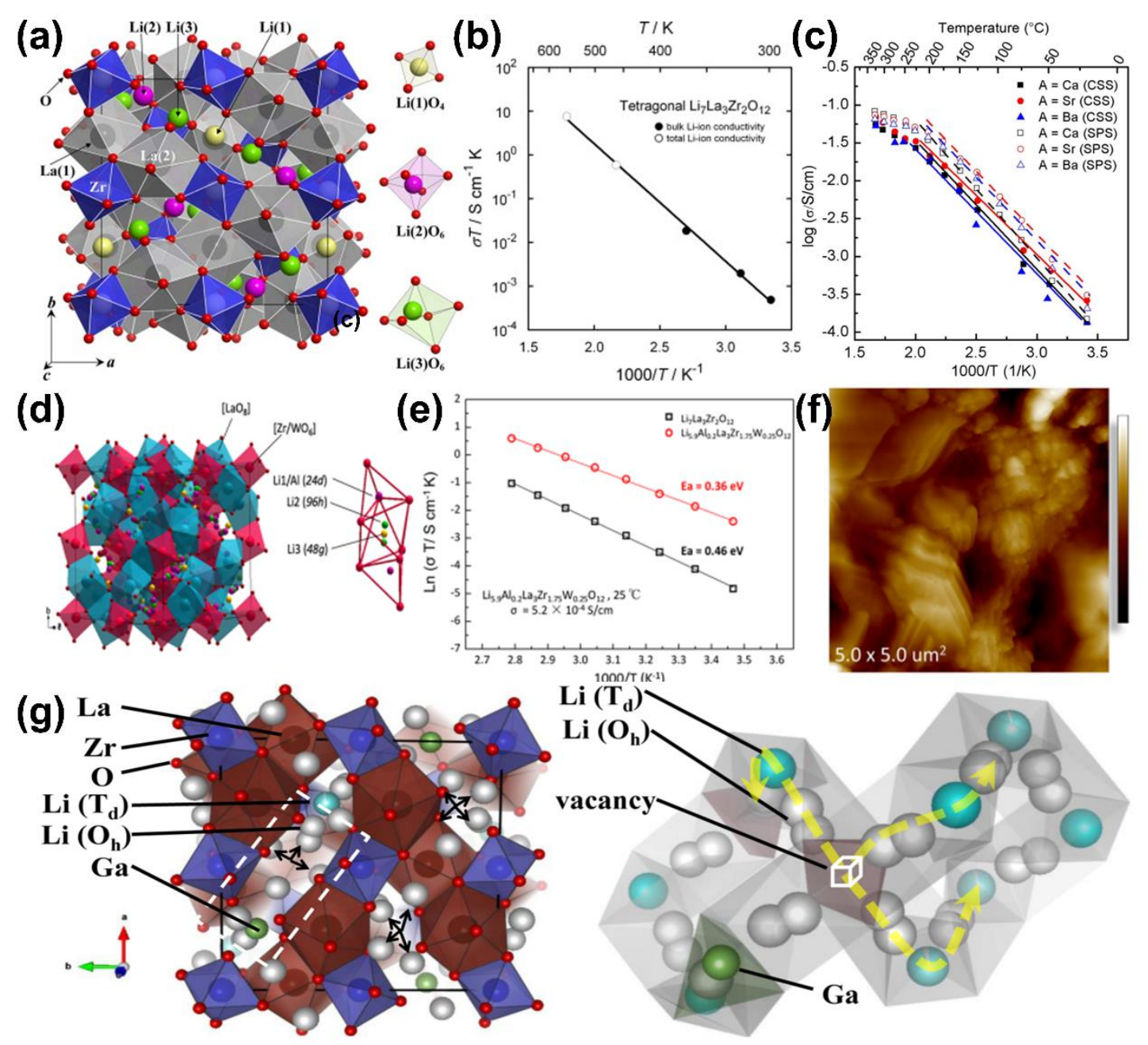

Fig. 7 (a) Crystal structure of tetragonal $\mathrm{Li}_{7} \mathrm{La}_{3} \mathrm{Zr}_{2} \mathrm{O}_{12}$. (b) Temperature dependence of the lithium ionic conductivity of tetragonal $\mathrm{Li}_{7} \mathrm{La}_{3} \mathrm{Zr}_{2} \mathrm{O}_{12}$ (reproduced from Ref. ${ }^{62}$, with permission from Nature). (c) Temperature dependence of the lithium ionic conductivity 
1 of $\mathrm{Li}_{6.5} \mathrm{La}_{2.5 \mathrm{~A} 0.5 \mathrm{TaZrO}}{ }_{22}\left(\mathrm{~A}=\mathrm{Ca}, \mathrm{Sr}, \mathrm{Ba}\right.$; reproduced from Ref. ${ }^{63}$, with permission from

2 the American Chemical Society). (d) Crystal model of garnet-structured

$3 \quad \mathrm{Li}_{5.9} \mathrm{Al}_{0.2} \mathrm{Laa}_{3} \mathrm{Zr}_{1.75} \mathrm{~W}_{0.25} \mathrm{O}_{12}$. (e) Arrhenius plots of $\mathrm{Li}_{7} \mathrm{La}_{3} \mathrm{Zr}_{2} \mathrm{O}_{12}$ and

$4 \quad \mathrm{Li} 5.9 \mathrm{Al}_{0.2} \mathrm{La}_{3} \mathrm{Zr}_{1.75} \mathrm{~W}_{0.25} \mathrm{O}_{12}$ to present ionic conductivity. (f) Atomic force microscopic 5 image of top view of the $\mathrm{Li}_{5.9} \mathrm{Al}_{0.2} \mathrm{La}_{3} \mathrm{Zr}_{1.75} \mathrm{~W}_{0.25} \mathrm{O}_{12}$ ceramic pellet. The color bar is in

6 the range of 0-650 $\mathrm{nm}$ (reproduced from Ref. ${ }^{64}$, with permission from the American

7 Chemical Society). (g) Garnet structure of $\mathrm{La}_{3} \mathrm{Zr}_{2} \mathrm{Li}_{7-3 \mathrm{x}} \mathrm{Ga}_{\mathrm{x} \square 2 \mathrm{x}} \mathrm{O}_{12}$, where blue circles

8 are $\mathrm{Zr}$ in octahedral $\left(\mathrm{O}_{\mathrm{h}}\right)$ coordination; dark red circles are La in dodecahedral

9 coordination; gray circles are $\mathrm{Li}$ in $\mathrm{O}_{\mathrm{h}}$ coordination; turquoise blue and green circles

10 are $\mathrm{Li}$ and $\mathrm{Ga}$ in tetrahedral $\left(\mathrm{T}_{\mathrm{d}}\right)$ coordination, respectively; and arrows represent

11 vacancies ( $\square$; reproduced from Ref. ${ }^{67}$, with permission from the American Chemical Society).

\subsubsection{Perovskite-type SSEs} SSESDs because of their ion conductivity of nearly $1 \times 10^{-3} \mathrm{~S} \mathrm{~cm}^{-1}$, potential window of $0-10.0 \mathrm{~V}$, and excellent thermal/chemical stability ${ }^{140-142}$. A perovskite-type SSE usually refers to a metal oxide whose molecular formula is $\mathrm{ABO}_{3}(\mathrm{~A}, \mathrm{~B}=$ metal, $\mathrm{O}=$ oxygen). SSEs are obtained through the replacement of a transition metal with lithium or sodium. Doping transition metals in SSEs can further improve their ionic conductivity. Hu et al. ${ }^{69}$ prepared a perovskite-type SSE $\mathrm{Li}_{0.33} \mathrm{La} 0.56 \mathrm{TiO}_{3}$ with a lithium 22 ionic conductivity of $1.7 \times 10^{-6} \mathrm{~S} \mathrm{~cm}^{-1}$ by replacing La with Li (Fig. 8a). After Ge- 
1 doping, they found that $\mathrm{Li} 0.43 \mathrm{La} 0.56 \mathrm{Ti} 0.95 \mathrm{Ge}_{0.05} \mathrm{O}_{3}$ exhibits a lithium ionic conductivity

2 of $1.2 \times 10^{-5} \mathrm{~S} \mathrm{~cm}^{-1}$ attributed to its improvement of the densification and structural

3 integrity. In addition to doping transition metals, anionic replacement can improve the

4 ionic conductivity of perovskite-type SSEs. Li et al. ${ }^{70}$ synthesized

$5 \quad \mathrm{Li}_{0.38} \mathrm{Sr}_{0.44} \mathrm{Ta}_{0.7} \mathrm{Hf}_{0.3} \mathrm{O}_{2.95} \mathrm{~F}_{0.05}$ through $\mathrm{F}$ - doping and obtained a lithium ionic

6 conductivity of $4.8 \times 10^{-4} \mathrm{~S} \mathrm{~cm}^{-1}$ at $25^{\circ} \mathrm{C}$ (Fig. 8b). Wu et al. ${ }^{143}$ utilized 3D- and 2D-

7 perovskite to modify garnet-type $\mathrm{SSE} \mathrm{Li}_{6.75} \mathrm{La}_{3} \mathrm{Zr}_{1.75} \mathrm{Ta}_{0.25} \mathrm{O}_{12}$. A Li| $\mathrm{SSE} \mid \mathrm{LiFePO}_{4}$ cell

8 exhibits specific capacities of 153 and $149 \mathrm{mAh} \mathrm{g}^{-1}$ for cells with 3D- and 2D-

9 perovskite after 50 cycles at $0.2 \mathrm{C}$, respectively. This result suggests an alternative path to increase battery capacity for SSESD development.

Amores et al. ${ }^{73}$ developed a sodium (Na)-rich perovskite-type SSE Na1.5 $\mathrm{La}_{1.5} \mathrm{TeO}_{6}$ with a monoclinic P21/n space group and sodium ions on A and B sites (Fig. 8c). They achieved a macroscopic ionic conductivity in the order of $10^{-8} \mathrm{~S} \mathrm{~cm}^{-1}$, which is the microscopic diffusion coefficient of sodium ions in the order of $10^{-2} \mathrm{~cm}^{2} \mathrm{~s}^{-1}$ (Fig. 8d). Zhao et al. ${ }^{74}$ synthesized a perovskite-type $\mathrm{SSE} \mathrm{Na}_{0.33} \mathrm{La}_{0.55} \mathrm{ZrO}_{3}$ with a sodium ion conductivity of $6.89 \times 10^{-7} \mathrm{~S} \mathrm{~cm}^{-1}$. Increasing the amount of $\mathrm{Sr}$ doping to 33 at $\%$ in $\mathrm{Na}_{1 / 3} \mathrm{La}_{1 / 3} \mathrm{Sr}_{1 / 3} \mathrm{ZrO}_{3}$ can increase the lattice parameter and densification of SSE and contribute to an enhanced ionic conductivity from $6.89 \times 10^{-7} \mathrm{~S} \mathrm{~cm}^{-1}$ to $1.025 \times 10^{-5} \mathrm{~S}$ $\mathrm{cm}^{-1}$.

Li- and Na-rich anti-perovskites have been widely explored as high-performance SSEs for applications in SSESDs because of their high structural tolerance and good formability ${ }^{144-146}$. Anti-perovskite-type SSE usually refers to a metal oxide whose 
1 molecular formula is $\mathrm{A}_{3} \mathrm{OX}(\mathrm{A}=$ metal, $\mathrm{O}=$ oxygen, $\mathrm{X}=$ halogen $) . \mathrm{Li}$ et al. $^{68}$ studied

2 lithium-rich anti-perovskite-type SSE $\mathrm{Li}_{3} \mathrm{OX}(\mathrm{X}=\mathrm{Cl}, \mathrm{Br})$ for lithium-ion batteries and

3 obtained an ion conductivity of $1.0 \times 10^{-5} \mathrm{~S} \mathrm{~cm}^{-1}$. The bulk and grain boundary (GB)

4 conductivities calculated from the equivalent circuit fitting are $1.02 \times 10^{-5}$ and $1.09 \times$

$5 \quad 10^{-6} \mathrm{~S} \mathrm{~cm}^{-1}$, respectively. Zhao et al. ${ }^{72}$ presented a dihalogen anti-perovskite SSE

$6 \mathrm{Li}_{3} \mathrm{OCl}_{0.5} \mathrm{Br}_{0.5}$ (Fig. 8e) to increase the ionic conductivity of lithium to $1.94 \times 10^{-3} \mathrm{~S}$

$7 \quad \mathrm{~cm}^{-1}$ (Fig. 8f) by introducing lithium ionic transport channels via doping and depleting.

8 Dawson et al. ${ }^{147}$ examined the defect chemistry and ionic transport in anti-perovskite-

9 type $\mathrm{SSE} \mathrm{Li}_{3} \mathrm{OCl}$ and $\mathrm{Na}_{3} \mathrm{OCl}$ and observed that alkali-halide Schottky defect pairs are

10 the dominant type of intrinsic disorder in these materials. Figs. $8 \mathrm{~g}$ and h show the Li-

11 and $\mathrm{Na}$-ion diffusion density maps for $\mathrm{Li}_{3} \mathrm{OCl}$ and $\mathrm{Na}_{3} \mathrm{OCl}$ with an alkali-halide partial

12 Schottky defect concentration of $\delta=0.038$ at $426.85{ }^{\circ} \mathrm{C}$. Chen et al. ${ }^{148}$ reported four

13 symmetric tilt ( $\Sigma 3$ and $\Sigma 5)$ GB effects on structural characteristics and ion transport in

14 anti-perovskite-type $\mathrm{SSE} \mathrm{Li}_{3} \mathrm{OCl}$. They confirmed that $\Sigma 5 \mathrm{GBs}$ structures are softer and

15 have a higher ionic conductivity than $\Sigma 3$ GBs. This result provides new insights into

16 the possible effect of GB types on the softness and ionic conductivity of SSE. However,

17 large solid-solid interfacial resistance between perovskite SSEs and electrode materials

18 is still a remarkable challenge that hinders the development of high-performance

19 SSESDs ${ }^{140}$. 
(a)

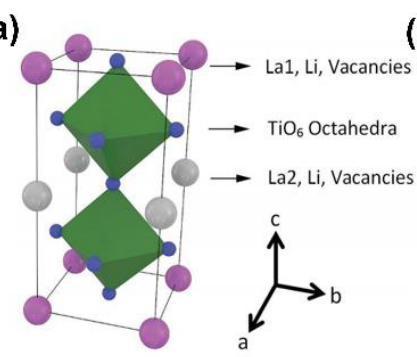

(e)

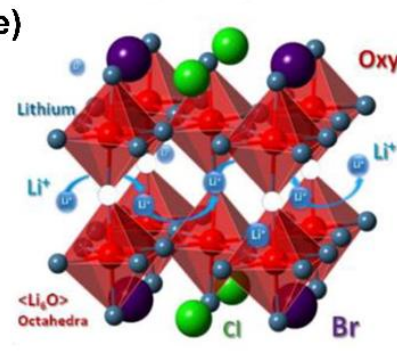

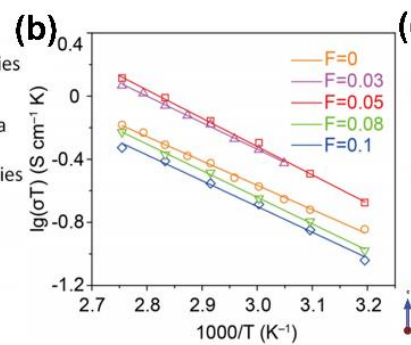

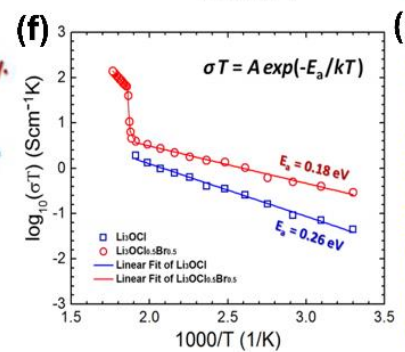

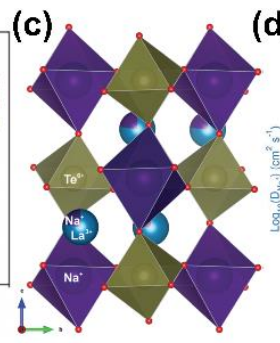

(d)
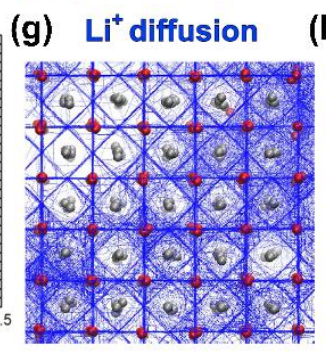

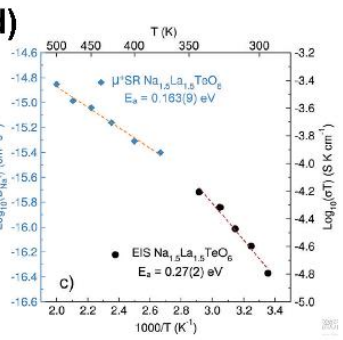

(h) $\mathrm{Na}^{+}$diffusion

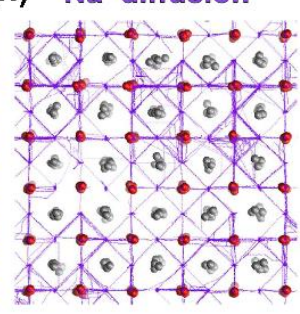

Fig. 8 (a) Crystal structure of $\mathrm{Li}_{0.33} \mathrm{La}_{0.56} \mathrm{TiO}_{3}$, including $\mathrm{La} 1$, $\mathrm{Li}$ vacancies at the $(0,0$,

0) site, $\mathrm{La} 2, \mathrm{Li}$ vacancies at the $(1 / 2,1 / 2,0)$ site, and $\mathrm{TiO}_{6}$ octahedra (reproduced from

Ref. $^{69}$, with permission from the Royal Society of Chemistry). (b) Lithium ionic conductivities of $\mathrm{Li}_{0.38} \mathrm{Sr}_{0.44} \mathrm{Ta}_{0.75-\mathrm{x}} \mathrm{Hf}_{0.25+\mathrm{x}} \mathrm{O}_{3-\mathrm{x}} \mathrm{F}_{\mathrm{x}}$ with $0 \leq \mathrm{x} \leq 0.1$ (reproduced from Ref. $^{70}$, with permission from Wiley). (c) Crystallographic representation of a $\mathrm{Na}_{1.5} \mathrm{La}_{1.5} \mathrm{TeO}_{6}$ structure with monoclinic P21/n symmetry. (d) Arrhenius plots of the ionic conductivity and diffusion coefficient of $\mathrm{Na}_{1.5} \mathrm{La}_{1.5} \mathrm{TeO}_{6}$ (reproduced from Ref. ${ }^{73}$, with permission from the Royal Society of Chemistry). (e) Anti-perovskite structure illustration of $\mathrm{Li}_{3} \mathrm{OCl}_{0.5} \mathrm{Br} 0.5$. (f) Arrhenius plots of $\log (\sigma \mathrm{T})$ versus $1 / \mathrm{T}$ for $\mathrm{Li}_{3} \mathrm{OCl}$ and $\mathrm{Li}_{3} \mathrm{OCl}_{0.5} \mathrm{Br}_{0.5}$ anti-perovskites (reproduced from Ref. ${ }^{72}$, with permission from the American Chemical Society). Trajectory plots of (g) lithium ions (blue) in $\mathrm{Li}_{3} \mathrm{OCl}$ and (h) sodium ions (purple) in $\mathrm{Na}_{3} \mathrm{OCl}$ with an alkali-chloride partial Schottky defect concentration of $\delta=0.038$ at $700 \mathrm{~K}$ for $10 \mathrm{~ns}$ simulations. $\mathrm{O}$ and $\mathrm{Cl}$ ions are given in red and silver, respectively (reproduced from Ref. ${ }^{147}$, with permission from the American Chemical Society). 


\subsubsection{Argyrodite-type SSEs}

Argyrodite-type SSEs, also known as LISICON-type SSEs ${ }^{79}$, have attracted considerable interest because of their high ion conductivity of up to $25 \times 10^{-3} \mathrm{~S} \mathrm{~cm}^{-1149}$, 150 151-155. Liu et al. ${ }^{156}$ synthesized an argyrodite-type SSE $\beta$-Li3 $\mathrm{PS}_{4}$ based on Li2 $\mathrm{S}$ and $\mathrm{P}_{2} \mathrm{~S}_{5}$ and achieved a lithium ionic conductivity of $1.6 \times 10^{-4} \mathrm{~S} \mathrm{~cm}^{-1}$. This material has prompted researchers to further explore this field. Subsequent developments include $\mathrm{Li}_{7} \mathrm{P}_{2} \mathrm{~S}_{8} \mathrm{I}\left(6.3 \times 10^{-4} \mathrm{~S} \mathrm{~cm}^{-1}\right)^{157}, 0.4 \mathrm{LiI}-0.6 \mathrm{Li}_{4} \mathrm{SnS}_{4}\left(4.1 \times 10^{-4} \mathrm{~S} \mathrm{~cm}^{-1}\right)^{158}, \mathrm{Na}_{3} \mathrm{SbS}_{4}(2.0 \times$ $\left.10^{-4} \mathrm{~S} \mathrm{~cm}^{-1}\right)^{159}$, and $\mathrm{Li}_{7} \mathrm{P}_{3} \mathrm{~S}_{11}\left(1.5 \times 10^{-3} \mathrm{~S} \mathrm{~cm}^{-1}\right)^{160}$. Among various potential SSE candidates (e.g., garnet and perovskite) for SSESDs, argyrodite-type SSEs are the most competitive because of their practicability and promising electrochemical performance $^{161}$.

Considerable efforts have been devoted to optimizing the ionic conduction pathway to obtain argyrodite-type SSEs with a high ionic conductivity. Zhang et al. ${ }^{77}$ studied halogen-doped $\mathrm{Li}_{6} \mathrm{PS}_{5} \mathrm{X}(\mathrm{X}=\mathrm{Cl}, \mathrm{Br}, \mathrm{I})$ and showed that $\mathrm{Li}_{6} \mathrm{PS}_{5} \mathrm{Cl}$ possesses the highest ionic conductivity of $1.8 \times 10^{-3} \mathrm{~S} \mathrm{~cm}^{-1}$ because of good lithium ion channels. Zhou et al. ${ }^{78}$ tuned the chlorine content $\left(\mathrm{Li}_{6-\mathrm{y}} \mathrm{PS}_{5-\mathrm{y}} \mathrm{Cl}_{1+\mathrm{y}}, \mathrm{y}=0.5\right)$ and improved the lithium ionic conductivity to $3.9 \mathrm{mS} \cdot \mathrm{cm}^{-1}$. Kamaya et al. ${ }^{80}$ doped Ge in an argyroditetype $\mathrm{SSE}$ to form $\mathrm{Li}_{10} \mathrm{GeP}_{2} \mathrm{~S}_{12}$ with a $1 \mathrm{D}$ lithium conduction pathway along the c axis composed of $\left(\mathrm{Ge}_{0.5} \mathrm{P}_{0.5}\right) \mathrm{S}_{4}$ tetrahedra and $\mathrm{LiS}_{6}$ octahedra (Fig. 9a) and obtained a high lithium ionic conductivity of $12 \times 10^{-3} \mathrm{~S} \mathrm{~cm}^{-1}$ at room temperature (Fig. 9b). Kraft et al. ${ }^{81}$ explored the influence of aliovalent substitution in argyrodite-type SSE $\mathrm{Li}_{6+\mathrm{x}} \mathrm{P}_{1-\mathrm{x}} \mathrm{Ge}_{\mathrm{x}} \mathrm{S}$ I I (Fig. 9c). After Ge content increases to $25 \mathrm{at} \%$, an anion site disorder 
1 is induced, and the activation barrier for ionic motion drops remarkably, leading to

2 ionic conductivities of $5.4 \pm 0.8 \times 10^{-3} \mathrm{~S} \mathrm{~cm}^{-1}$ in a cold-pressed state and $18.4 \pm 2.7 \times$

$3 \quad 10^{-3} \mathrm{~S} \mathrm{~cm}^{-1}$ upon sintering at $550{ }^{\circ} \mathrm{C}$ (Fig. 9d).

Zhang et al. $^{82}$ reported an argyrodite-type $\mathrm{SSE} \mathrm{Na}_{11} \mathrm{Sn}_{2} \mathrm{PS}_{12}$ (sodium ionic conductivity of $1.4 \times 10^{-4} \mathrm{~S} \mathrm{~cm}^{-1}$ ) with sodium ion conduction pathways that flow through equienergetic sodium sulfur octahedra interconnected by partial vacancy crossover sites in all crystallographic dimensions. They provided insights into the underlying isotropic 3D fast-ion conduction (Fig. 9e). Ramos et al. ${ }^{83}$ synthesized argyrodite-type SSE $\mathrm{Na}_{11} \mathrm{Sn}_{2} \mathrm{SbS}_{12}$ by replacing $\mathrm{P}$ with $\mathrm{Sb}$. $\mathrm{Na}_{11} \mathrm{Sn}_{2} \mathrm{SbS}_{12}$ possesses the same structural framework as $\mathrm{Na}_{11} \mathrm{Sn}_{2} \mathrm{PS}_{12}$, while sodium ions transport through similar $3 \mathrm{D}$ pathways, thereby exhibiting an enhanced sodium ion conductivity of $0.56 \mathrm{mS} \cdot \mathrm{cm}^{-1}$. Yu et al. ${ }^{84}$ fabricated argyrodite-type $\mathrm{SSE} \mathrm{Na}_{10.8} \mathrm{Sn}_{1.9} \mathrm{PS}_{11.8}$ by adjusting the element ratio. They obtained a large number of intrinsic sodium vacancies and 3D sodium ionic conduction pathways (Fig. 9f) and a high ionic conductivity of $6.7 \times 10^{-4} \mathrm{~S} \mathrm{~cm}^{-1}$ at $25^{\circ} \mathrm{C}$. Duchardt et al. ${ }^{85}$ presented an argyrodite-type SSE Na ${ }_{11} \mathrm{Sn}_{2} \mathrm{PS}_{12}$, which possesses a sodium ionic conductivity close to $4 \times 10^{-3} \mathrm{~S} \mathrm{~cm}^{-1}$. These studies have emphasized the importance of vacancies, which interconnect ion migration pathways in a $3 \mathrm{D}$ manner to improve SSE conductivity.

Although argyrodite-type SSEs usually possess a higher conductivity than their oxide counterparts, the former are unstable against moisture and tend to produce toxic $\mathrm{H}_{2} \mathrm{~S}$ gas $^{94}$. Zhu et al. ${ }^{76}$ designed a new kind of argyrodite-type SSE Li-B-H with an ionic conductivity of $2.7 \times 10^{-4} \mathrm{~S} \mathrm{~cm}^{-1}$. $\mathrm{LiH}$ and $\left[\mathrm{Li}_{2} \mathrm{~B}_{12} \mathrm{H}_{11+1 / n}\right]_{\mathrm{n}}$ are formed in a $\mathrm{LiBH}_{4}$ matrix 
1 in situ, and an interface layer between $\left[\mathrm{Li}_{2} \mathrm{~B}_{12} \mathrm{H}_{11+1 / n}\right]_{\mathrm{n}}$ and $\mathrm{LiBH}_{4}$ is responsible for a

2 high ion conductivity. Future research will focus on increasing the ionic conductivity

3 of argyrodite-type SSEs without sulfur and developing novel argyrodite-type SSEs.

(a)

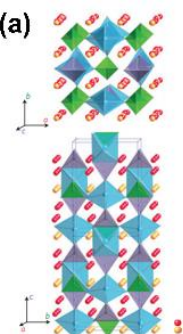

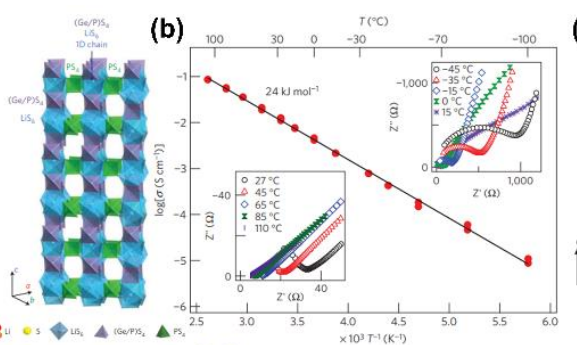
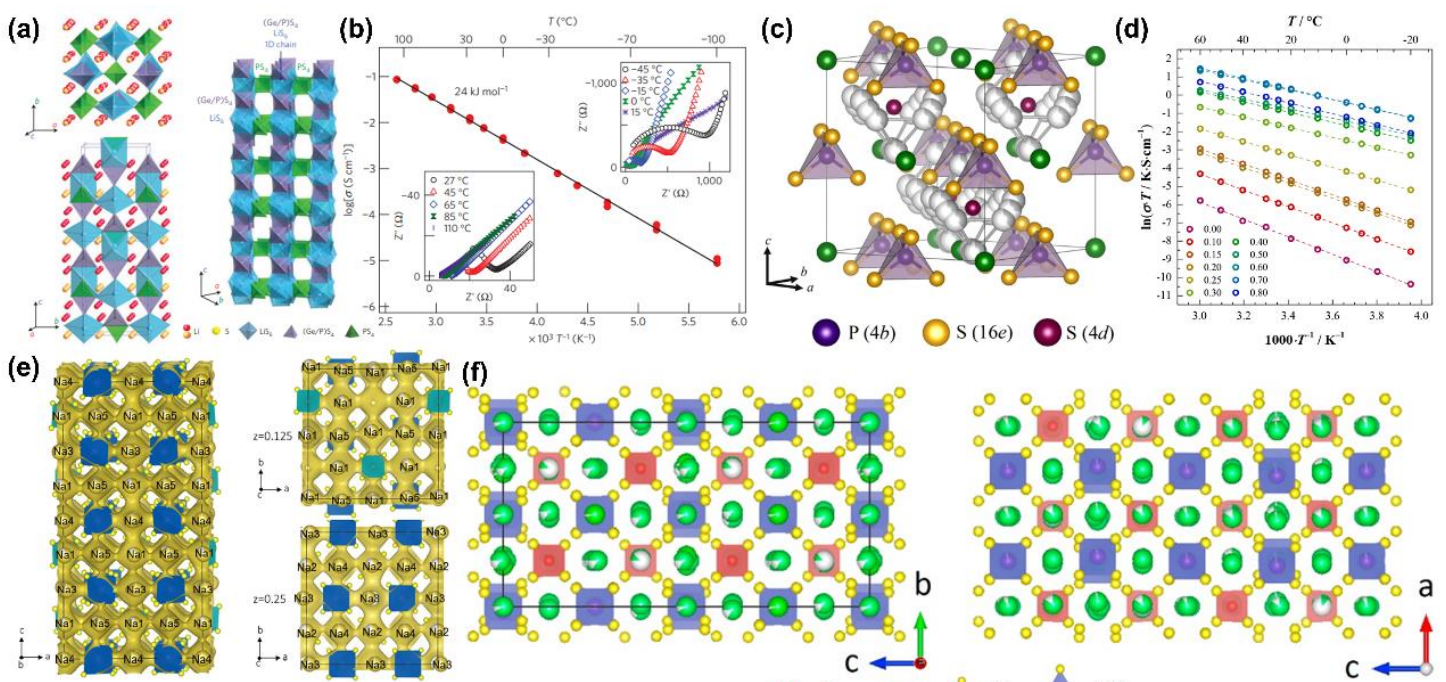

(i)
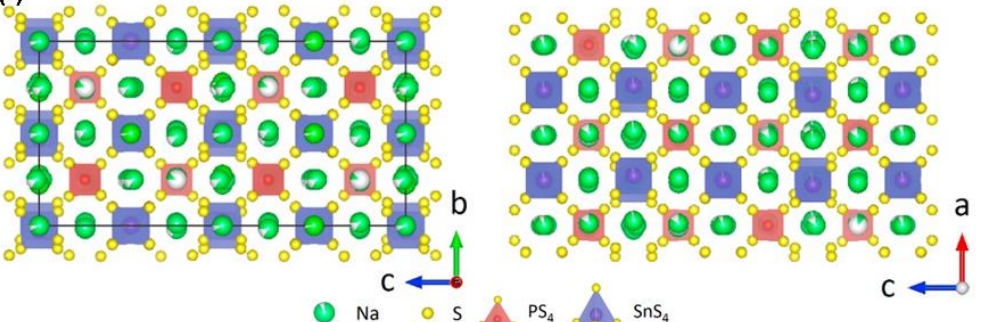

Fig. 9 (a) Crystal structure of $\mathrm{Li}_{10} \mathrm{GeP}_{2} \mathrm{~S}_{12}$, framework structure, and lithium ions that participate in ionic conduction. (b) Lithium ionic conductivity of $\mathrm{Li}_{10} \mathrm{GeP}_{2} \mathrm{~S}_{12}$, impedance plots of the conductivity data from low to high temperatures, and Arrhenius conductivity plots (reproduced from Ref. ${ }^{80}$, with permission from Nature). (c) Crystal structure of $\mathrm{Li}_{6} \mathrm{PS}_{5} \mathrm{X}(\mathrm{X}=\mathrm{I})$ in which $\mathrm{I}^{-}$forms a face-centered cubic lattice, with $\mathrm{PS}_{4}$ tetrahedra in $\mathrm{Oh}_{\mathrm{h}}$ voids and a free $\mathrm{S}^{2-}$ on half of the tetrahedral vacant sites (4d). (d) Arrhenius plots of the conductivity values for $\mathrm{Li}_{6+}{ }_{+} \mathrm{P}_{1-\mathrm{x}} \mathrm{Ge}_{\mathrm{x}} \mathrm{S}_{5} \mathrm{I}(0 \leq x \leq 0.8$; reproduced from Ref. ${ }^{81}$, with permission from the American Chemical Society). (e) Sodium ion probability density isosurface (yellow) obtained from ab initio molecular dynamics (AIMD) studies at $1050 \mathrm{~K}$ for $40 \mathrm{ps}$. Sodium diffusion along the c axis involves a pathway along $-\mathrm{Na}(4)-\mathrm{Na}(1)-\mathrm{Na}(3)-\mathrm{Na}(1)-$ chains; the sodium ion probability density obtained from the AIMD sodium ion trajectories in the ab plane shows the pathways at 
$1 \mathrm{z}=0.125$ and $\mathrm{z}=0.25$ (reproduced from Ref. ${ }^{82}$, with permission from the Royal Society

2 of Chemistry). (f) Crystal structure of $\mathrm{Na}_{10.8} \mathrm{Sn}_{1.9} \mathrm{PS}_{11.8}$ and different views of a single

3 crystal; white in the sodium sphere indicates the ratio of vacancies (reproduced from

$4 \quad$ Ref. $^{84}$, with permission from Elsevier).

\subsubsection{Phosphate-type SSEs}

The importance of exploring new SSEs for SSESDs has led to significant interests in phosphate-type materials because of their high ionic conductivities and low GB resistance ${ }^{95,162}$. Phosphate-type SSEs, also known as NASICON-type SSEs, are formed by linking phosphorus oxide tetrahedron and metal oxygen octahedron. Ramar et al. ${ }^{87}$ prepared phosphate-type SSE $\mathrm{Li}_{1.1} \mathrm{Zr}_{1.9} \mathrm{La}_{0.1}\left(\mathrm{PO}_{4}\right)_{3}$ with a lithium ionic conductivity of $7.2 \times 10^{-5} \mathrm{~S} \mathrm{~cm}^{-1}$. Yan et al. ${ }^{89}$ reported a microwave sintering method to produce phosphate-type SSE Li1.5 $\mathrm{Al}_{0.4 \mathrm{Ga}}{ }_{1.1} \mathrm{Ge}_{1.5}\left(\mathrm{PO}_{4}\right)_{3}$ that has a lithium ionic conductivity of $6.67 \times 10^{-4} \mathrm{~S} \mathrm{~cm}^{-1}$

Phosphate-type SSEs with new compositions and crystal structures should be developed to achieve high ionic conductivities ${ }^{163-165}$. Liang et al. ${ }^{86}$ synthesized phosphate-type $\mathrm{SSE} \mathrm{LiTi}_{2}\left(\mathrm{PO}_{4}\right)_{3}$ that has a lithium ionic conductivity of $2.1 \times 10^{-5} \mathrm{~S}$ $\mathrm{cm}^{-1}$ and is made of a 3D framework of $\mathrm{TiO}_{6}$ octahedra and $\mathrm{PO}_{4}$ tetrahedra (Fig. 10a), thereby providing channels for lithium ion transport ${ }^{166}$. Yi et al. ${ }^{88}$ synthesized $\mathrm{Li}_{1.3} \mathrm{Al}_{0.3} \mathrm{Ti}_{1.7}\left(\mathrm{PO}_{4}\right)_{3}$ powder via a sol-gel route and sintered the powder at $1000{ }^{\circ} \mathrm{C}$ for $6 \mathrm{~h}$ to produce phosphate-type SSE Li1.3Al0.3 $\mathrm{Ti}_{1.7}\left(\mathrm{PO}_{4}\right)_{3}$, which shows a high lithium ionic conductivity of $4.2 \times 10^{-4} \mathrm{~S} \mathrm{~cm}^{-1}$ because of an increase in the grain size and 
1 density of $\mathrm{Li}_{1.3} \mathrm{Al}_{0.3} \mathrm{Ti}_{1.7}\left(\mathrm{PO}_{4}\right)_{3}$ ceramic (Fig. 10b).

2

Deng et al. ${ }^{92}$ studied Sc-substituted phosphate-type SSE $\mathrm{Na}_{3} \mathrm{Sc}_{\mathrm{x}} \mathrm{Zr}_{2-\mathrm{x}}\left(\mathrm{SiO}_{4}\right)_{2-\mathrm{x}}\left(\mathrm{PO}_{4}\right)_{1+\mathrm{x}}$ and $\mathrm{Na}_{2} \mathrm{Sc}_{\mathrm{y}} \mathrm{Zr}_{2-\mathrm{y}}\left(\mathrm{SiO}_{4}\right)_{1-\mathrm{y}}\left(\mathrm{PO}_{4}\right)_{2+\mathrm{y}} \quad(\mathrm{x}, \mathrm{y}=0-1) . \quad$ The conduction pathways of $\mathrm{Na}+$ are plotted via three different approaches (Fig. 10c). (i) Molecular dynamics (MD) density plots of sodium ion reveal the migration pathways and lattice regions that are most frequently traversed by mobile $\mathrm{Na}$ ions. (ii) Bond valence energy landscapes (BVELs) obtained via the bond valence sum method require a crystal structure as an input and can probe possible ion diffusion pathways with minimal computational cost. (iii) Maximum entropy method (MEM)/Rietveld analysis involves scattering densities by giving the maximum variance of the calculated structure factors within the standard deviations of the observed ones. Sodium ion diffusion in SSEs is 3D, and a continuous exchange of sodium ions between $\mathrm{Na}(1)$ and $\mathrm{Na}(2)$ sites is present. $\mathrm{Na}_{3} \mathrm{Sc}_{0.25} \mathrm{Zr}_{1.75}\left(\mathrm{SiO}_{4}\right)_{1.75}\left(\mathrm{PO}_{4}\right)_{1.25}$ shows a sodium ionic conductivity of about $0.1 \mathrm{~S} \mathrm{~cm}^{-1}$ (Fig. 10d). Kehne et al. ${ }^{95}$ reported Sc-substituted phosphate-type SSE $\mathrm{Na}_{3} \mathrm{Zr}_{2}\left(\mathrm{SiO}_{4}\right)_{2}\left(\mathrm{PO}_{4}\right)$ with a sodium ionic conductivity of $4 \times 10^{-3} \mathrm{~S}$ $\mathrm{cm}^{-1}$ for $\mathrm{Na}|\mathrm{SSE}| \mathrm{NaxCoO} 2$ cells, which show a specific capacity of $150 \mathrm{mAh} \mathrm{g}^{-1}$ at 6.0 C for 100 cycles.

Wang et al. ${ }^{167}$ investigated the diffusion pathway of aluminum ion in phosphatetype $\mathrm{SSE}\left(\mathrm{Al}_{0.2} \mathrm{Zr} 0.8\right)_{20} /{ }_{19} \mathrm{Nb}\left(\mathrm{PO}_{4}\right)_{3}$ for rechargeable solid-state aluminum-ion batteries. $\left(\mathrm{Al}_{0.2} \mathrm{Zr}_{0.8}\right)_{20} /{ }_{19} \mathrm{Nb}\left(\mathrm{PO}_{4}\right)_{3}$ has a rhombohedral structure consisting of a framework of $(\mathrm{Zr}, \mathrm{Nb}) \mathrm{O}_{6}$ octahedra that shares corners with $\left(\mathrm{PO}_{4}\right)$ tetrahedral. Aluminim ions occupy trigonal antiprisms, thereby exhibiting extremely large displacement factors. Wang et 
1 al. ${ }^{167}$ suggested a strong displacement of aluminum ions along the c axis of a unit cell

2 as they diffuse across the structure via a vacancy mechanism (Fig. 10e). An

$3 \mathrm{Al}|\mathrm{SSE}| \mathrm{V}_{2} \mathrm{O}_{5}$ nanorod/rGO cell presents initial discharge capacities of 7.5 and 10

$4 \mathrm{mAh} \cdot \mathrm{g}^{-1}$ at $120{ }^{\circ} \mathrm{C}$ and $150{ }^{\circ} \mathrm{C}$ from $0.01 \mathrm{~V}$ to $2.0 \mathrm{~V}$ versus $\mathrm{Al}^{3+} / \mathrm{Al}$ at $2 \mathrm{~mA} \cdot \mathrm{g}^{-1}$,

5 respectively (Fig. 10f). This research provides a basis for studying solid-state

6 aluminum-ion batteries.

In general, phosphate-type SSEs are prepared through sintering at high

8 temperatures $\left(1000{ }^{\circ} \mathrm{C}\right)$ for a prolonged time, which is unfavorable for industrial

9 applications ${ }^{168,169}$. New research should be conducted to prepare phosphate-type SSEs

10 at low temperatures. 


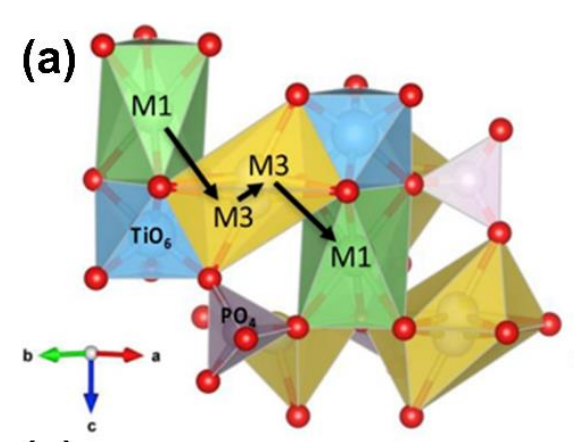

(c)

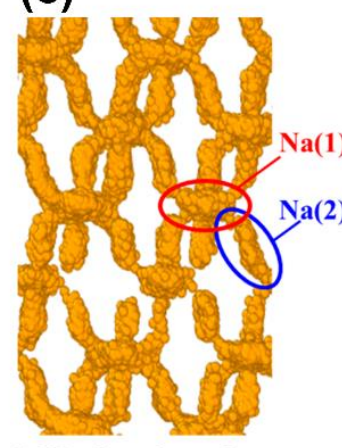

MD density plot

BVEL

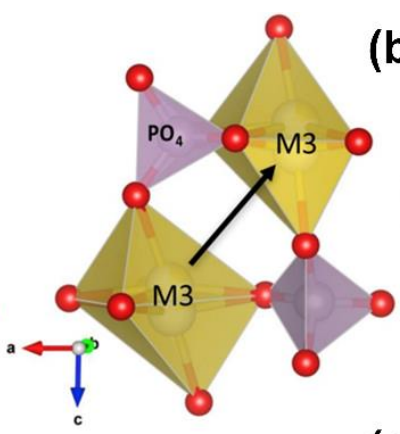

(d)

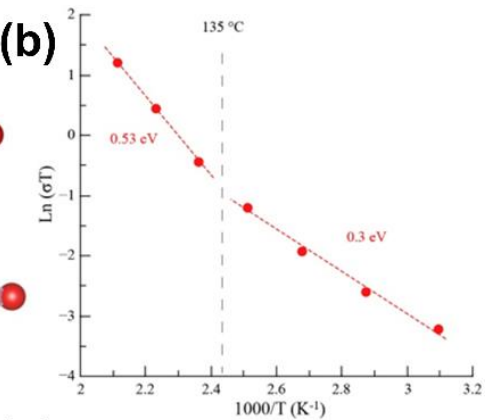

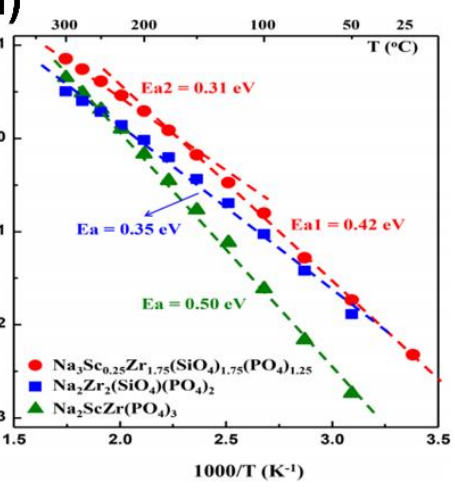
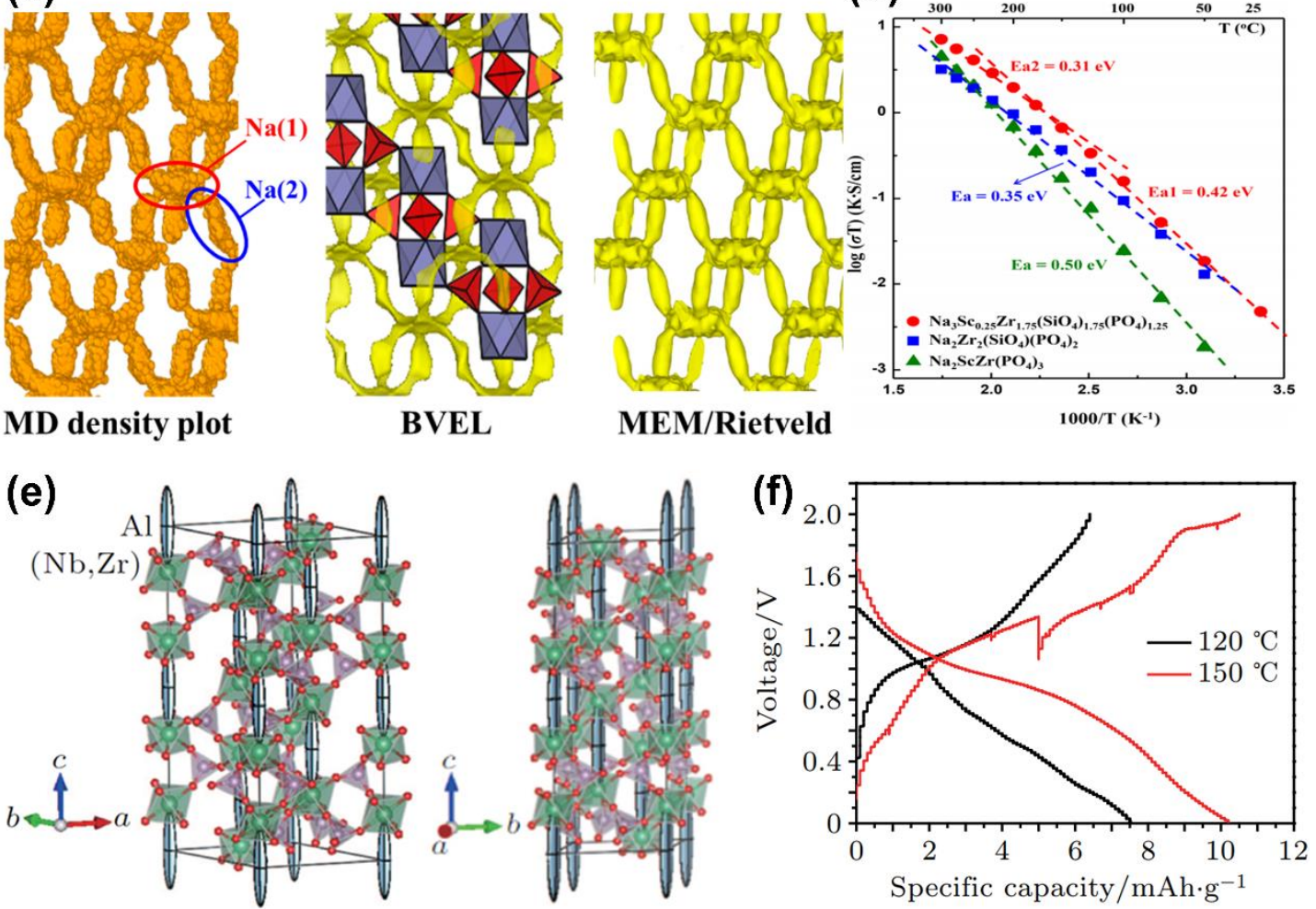

Fig. 10 (a) Predominant lithium ion conduction pathway at room temperature and possible predominant lithium ion conduction pathway at $>135{ }^{\circ} \mathrm{C}$ (reproduced from Sodium ion diffusion pathways obtained from different techniques: (1) left, MD density

7 plot of $\mathrm{Na}^{+}(473 \mathrm{~K})$ accumulating for $1 \mathrm{~ns}$ with a step of $1 \mathrm{ps}$; (2) center, BVEL methods

8 with an iso-energy surface value of $1.0 \mathrm{eV}$; (3) right, MEM/Rietveld method with an iso-surface level of $0.05 \mathrm{fm} \AA^{-3}$; and (d) Arrhenius plot for $\mathrm{Na}_{3} \mathrm{Sc}_{0.25} \mathrm{Zr}_{1.75}\left(\mathrm{SiO}_{4}\right)_{1.75}(\mathrm{PO} 4)_{1.25}(\mathrm{red}), \mathrm{Na}_{2} \mathrm{Zr}_{2}\left(\mathrm{SiO}_{4}\right)\left(\mathrm{PO}_{4}\right)_{2}$ (blue), and $\mathrm{Na}_{2} \mathrm{ScZr}\left(\mathrm{PO}_{4}\right)_{3}$ 
1 (green; reproduced from Ref. ${ }^{92}$, with permission from the American Chemical Society).

2 (e) Crystal structure of $\left(\mathrm{Al}_{0.2} \mathrm{Zr}_{0.8}\right)_{20} /{ }_{19} \mathrm{Nb}\left(\mathrm{PO}_{4}\right)_{3}$ consisting of a framework of

$3 \quad(\mathrm{Nb}, \mathrm{Zr}) \mathrm{O}_{6}$ octahedra sharing corners with $\mathrm{PO}_{4}$ tetrahedra. (f) Initial discharge-charge

4 profiles of a solid-state $\mathrm{Al}|\mathrm{SSE}| \mathrm{V}_{2} \mathrm{O}_{5}$ nanorod $/ \mathrm{rGO}$ cell at $2 \mathrm{~mA} \cdot \mathrm{g}^{-1}$ at $120{ }^{\circ} \mathrm{C}$ and

$5 \quad 150{ }^{\circ} \mathrm{C}$, respectively; reproduced from Ref. ${ }^{167}$, with permission from the Chinese

$6 \quad$ Physical Society and IOP).

7

4.2 Organic SSEs, including gel, single polymer, blending polymer and polymer with filling types

Inorganic SSEs have interface problems and are usually prepared at hightemperature calcination. By contrast, organic SSEs, such as gel, single polymer, blending polymer and polymer with filling types, attract considerable interests because of their simple polymerization process at room temperature and good interface contact.

\subsubsection{Gel-type SSEs}

Gel-type SSEs have been widely explored for flexible solid-state supercapacitors and other aqueous solid-state batteries ${ }^{170}$. A good gel-type SSE usually requires a combination of a high ion migration rate, a reasonable mechanical strength, and a robust water retention ability in a solid state to ensure excellent durability ${ }^{171}$. .atoszynska et al. ${ }^{96}$ prepared a mechanically stable nonaqueous proton-conducting gel-type SSE based on methacrylate monomers and diphenyl phosphate. The use of phosphoric acid ester as a proton donor has led to an increase in operation voltage window $(0-1.3 \mathrm{~V})$ and 
1 electrolyte ionic conductivity $\left(3.1 \times 10^{-4} \mathrm{~S} \mathrm{~cm}^{-1}\right)$. Chodankar et al. ${ }^{98}$ reported gel-type

2 SSE polyvinylpyrrolidone $/ \mathrm{LiClO}_{4}$ for flexible solid-state supercapacitors. A symmetric

$3 \quad \mathrm{MnO}_{2}|\mathrm{SSE}| \mathrm{MnO}_{2}$ supercapacitor yields an operating potential window of $1.6 \mathrm{~V}$ and an

4 energy density of $23 \mathrm{Wh} \mathrm{kg}^{-1}$ at a power density of $1.9 \mathrm{~kW} \mathrm{~kg}^{-1}$. Veerasubramani et

5 al. ${ }^{172}$ used a gel-type SSE composed of polyvinyl alcohol/ $/ \mathrm{H}_{3} \mathrm{PO}_{4} / \mathrm{Na}_{2} \mathrm{MoO}_{4}$ to fabricate

6 a flexible cable-type supercapacitor. A graphene oxide|SSE|graphene oxide

$7 \quad$ supercapacitor exhibits a length capacitance and energy density of $18.75 \mathrm{mF} \mathrm{cm}^{-1}$ and

$8 \quad 2.6 \mathrm{mWh} \mathrm{cm}^{-1}$, respectively. Su et al. ${ }^{173}$ used an aqueous polyvinylpyrrolidone-based

9 gel-type SSE to assemble a $\mathrm{Zn}|\mathrm{SSE}| \mathrm{FeCo}-\mathrm{N}-\mathrm{C}$ cell and demonstrated a good charging-

10 discharging performance, a long life time $(12 \mathrm{~h})$, and a high flexibility. Luo et al. ${ }^{174}$

11 designed a gel-type SSE by utilizing tetraethylene glycol dimethyl ether, ethoxylated

12 trimethylolpropane triacrylate, and 2-hydroxy-2-methyl-1-phenyl-1-propanon for

13 lithium-oxygen batteries ( $\mathrm{Li}|\mathrm{SSE}|$ reduced graphene oxide@ $\mathrm{RuO}$ ) that display a

14 voltage of higher than $2.2 \mathrm{~V}$ after 140 cycles at $0.4 \mathrm{~mA} \mathrm{~cm}^{-2}$, with a capacity of 1000 $15 \quad \mathrm{mAh} \mathrm{g}^{-1}$.

Chodankar et al. ${ }^{175}$ reported that the water contact angles of polyvinyl alcohol (Fig. 11aA), hydroxymethyl cellulose (Fig. 11aB), and polyethylene oxide (Fig. 11aC) gel electrolytes are $10^{\circ}, 36.8^{\circ}$, and $63.3^{\circ}$, respectively. This result indicates that polyvinyl

19 alcohol gel electrolytes possess a hydrophilic nature. Thus, a gel-type SSE composed of polyvinyl alcohol/LiClO 4 has a hydrophilic nature and a good contact with active electrode materials. This trait is beneficial to the electrochemical performance of energy storage devices. Peng et al. ${ }^{99}$ reported zwitterionic gel-type SSE polypropylsulfonate 
1 dimethylammonium propylmethacrylamide (PPDP)/LiCl with the synergic advantages

2 of robust water retention ability and ion migration channels, thereby manifesting a

3 superior electrochemical performance. As illustrated in Fig. 11b, PPDP possesses a

4 positively charged quaternary ammonium group and a negatively charged sulfonate

5 group on the same monomeric unit. Given the strong electrostatic interactions between

6 charged groups and water molecules, PPDP is highly hydrated by the surrounding water

7 molecules with a robust water retention ability. An ion migration channel can be

8 developed within a hydration layer along PPDP chains between two electrodes by

9 applying an external electric field because of the robust water retention ability of PPDP

10 gel electrolytes. Supercapacitors with PPDP gel electrolytes yield specific capacitances

11 of $300.8,298.2,292.4,279.6,270.4$, and $256.0 \mathrm{~F} \mathrm{~cm}^{-3}$ at current densities of $0.8,1,2$,

4,8 , and $20 \mathrm{~A} \mathrm{~cm}^{-3}$ in a solid state, respectively. These values are larger than those of supercapacitors with polyvinyl alcohol (PVA) gel electrolytes (Fig. 11c). Pandey et al. ${ }^{97}$

14 designed a flexible, free-standing, thermostable gel-type SSE based on plastic crystalline succinonitrile (SN) and ionic liquid (IL) 1-butyl-3-methylimidazolium tetrafluoroborate entrapped in poly(vinylidene fluoride-co-hexafluoropropylene). The temperature dependence of the ionic conductivity of gel SSEs leads to ionic conductivities ranging from $\sim 0.5 \times 10^{-3} \mathrm{~S} \mathrm{~cm}^{-1}$ at $-30{ }^{\circ} \mathrm{C}$ to $\sim 15 \times 10^{-3} \mathrm{~S} \mathrm{~cm}^{-1}$ at $80{ }^{\circ} \mathrm{C}$ (Fig. 11d). Thermal studies have confirmed that IL-SN-gel SSEs remain stable in the same gel phase within a wide temperature range of $-30{ }^{\circ} \mathrm{C}$ to $90{ }^{\circ} \mathrm{C}$ (Fig. 11e). Xia et al. ${ }^{176}$ reported a gel-type SSE based on poly(vinylidene fluoride-cohexafluoropropylene) for solid-state lithium-sulfur (Li|SSE|sulfur) batteries. Thus, 
1 these batteries present a high initial capacity of $918 \mathrm{mAh} \mathrm{g}^{-1}$ at $0.05 \mathrm{C}$ and an improved

2 cycle performance for 40 cycles compared with those of their counterparts with liquid

3 electrolytes because of the effective suppression of the shuttle effect of polysulfides

4 (Fig. 11f).

5 Gel-type SSEs play an important role in the development of flexible SSESDs

6 because of their high ionic conductivity and good flexibility. However, the poor

7 mechanical properties of gel-type SSEs pose a safety hazard in dynamic applications,

8 and the mechanical properties of gel-type SSEs should be improved on the basis of gel

9 selection, additive addition, and solidification condition control. Embedding a

10 conventional energy storage device separator during the solidification of a gel-type SSE

11 is also an effective method to improve its safety. Our group ${ }^{214,215}$ also demonstrated

12 that the solidification of gel-type SSEs on an electrode surface helps improve the

13 electrochemical performance of devices. Our study is also a valuable reference for the

14 assembly of high-performance flexible devices. 


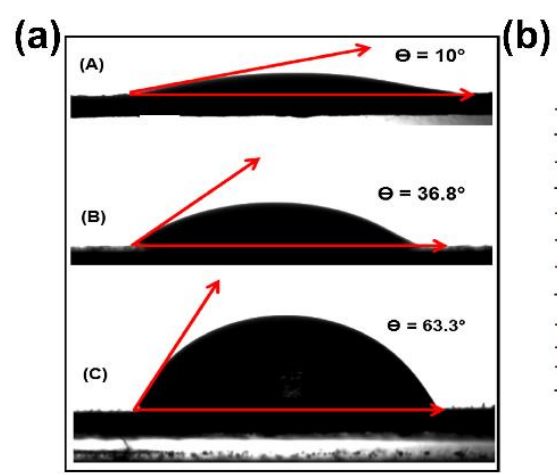

(c)

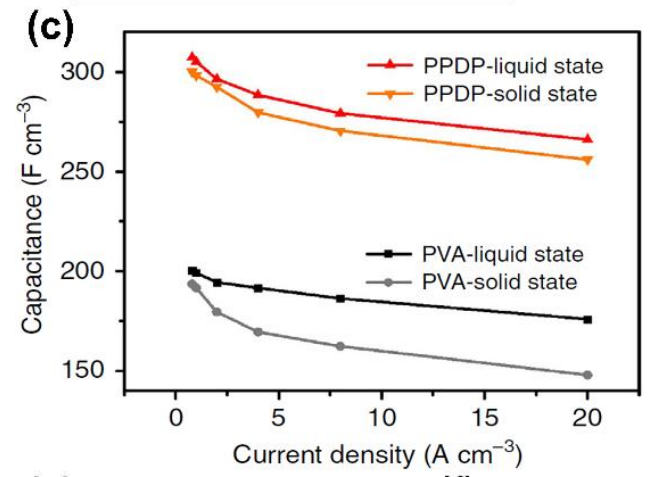

(e)

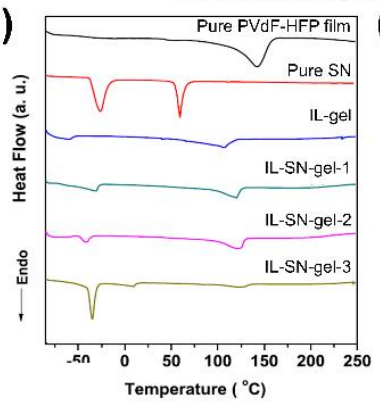

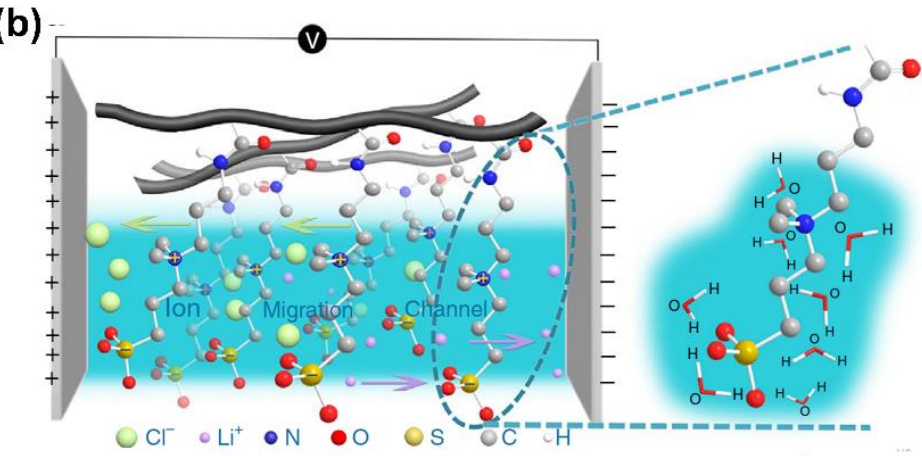

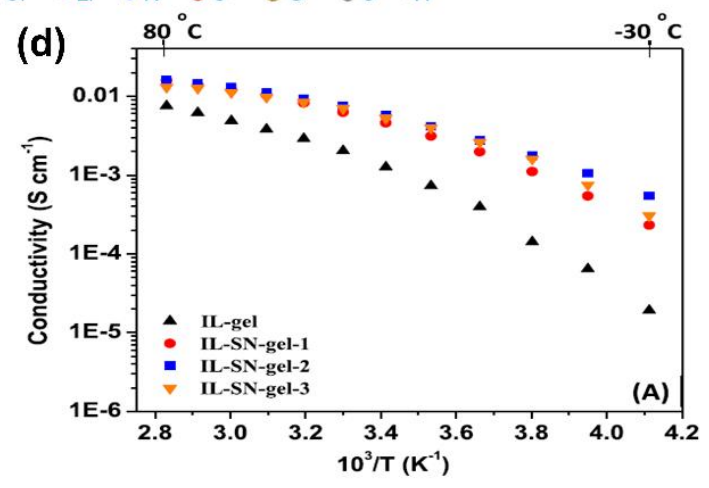

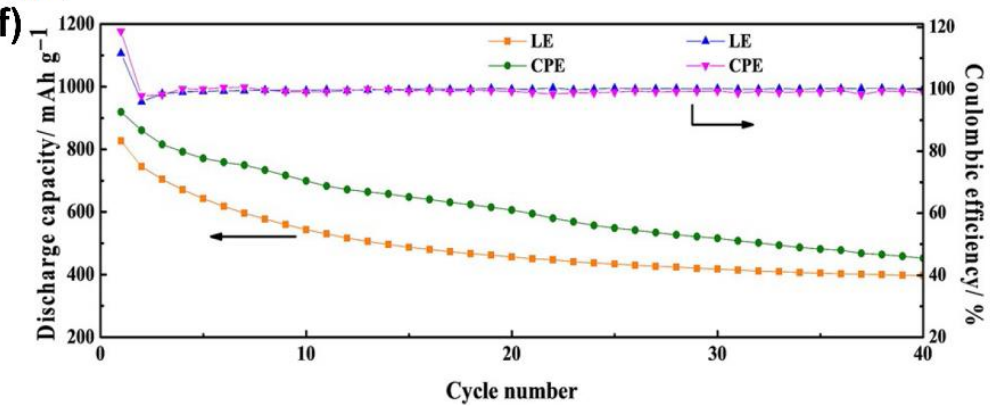

Fig. 11 (a) Contact angles of polyvinyl alcohol (A), hydroxymethyl cellulose (B), and polyethylene oxide (C) gel electrolyte film on a substrate (reproduced from Ref. ${ }^{175}$, with permission from Elsevier). (b) Schematic of a gel SSE applied to electrodes. An ion migration channel is formed by applying an external electric field. (c) Comparison of the specific capacitances for graphene-based supercapacitors between poly (propylsulfonate dimethylammonium propylmethacrylamide) and polyvinyl alcohol gel electrolytes at different current densities (reproduced from Ref. ${ }^{99}$, with permission from Nature). (d) Temperature dependence of the ionic conductivity of a gel SSE containing different amounts of crystalline SN and IL. (e) Differential scanning calorimeter curves of pure poly(vinylidene fluoride-co-hexafluoropropylene) film, pure 
1 SN, IL-gel, IL-SN-gel-1, IL-SN-gel-2, and IL-SN-gel-3 (reproduced from Ref. ${ }^{97}$, with

2 permission from Elsevier). (f) Cycling performance of Li|liquid electrolyte|sulfur and

$3 \mathrm{Li}|\mathrm{SSE}|$ sulfur cells at $0.05 \mathrm{C}$ (reproduced from Ref. ${ }^{176}$, with permission from Wiley).

4

\subsubsection{Single polymer-type SSEs}

Dry single polymer-type SSEs have been extensively investigated because of their flexibility, wide range of operation temperature, and excellent cycle life ${ }^{177}$. Polymertype SSEs can effectively suppress the growth of metal dendrites and thus avoid the short circuit of batteries ${ }^{178} 179180$. Various polymersincluding polyethylene oxide ${ }^{181}$, polyacrylonitrile ${ }^{182}$, and poly(methyl methacrylate) ${ }^{183}$, have been widely studied as SSEs.

In single polymer-type SSEs, microscopic ion transport is related to the segmental motion of polymer chains above the glass transition temperature ${ }^{184}$, thereby creating free volumes for hopping ions that coordinate with polar groups. An ion can hop from one coordinating site to another, thereby accompanying the segmental motion of polymer chains ${ }^{185}$. In an electrical field, long distance transport is realized by continuous hopping.

Zeng et al. ${ }^{103}$ designed a polymer-type SSE with an interpenetrating network of poly(ether acrylate) (ipn-PEA, Fig. 12a), thereby exhibiting high mechanical strength (ca. $12 \mathrm{GPa}$, Fig. 12b) and good ionic conductivity $\left(2.2 \times 10^{-4} \mathrm{~S} \mathrm{~cm}^{-1}\right)$. A LilipnPEA|LiFePO4 cell within $4.5 \mathrm{~V}_{\text {vs }} \mathrm{Li}^{+} / \mathrm{Li}$ operates effectively at $5.0 \mathrm{C}$ (Fig. 12c). Feng et al. ${ }^{102}$ designed a polymer-type SSE based on a cyclic carbonate-cyclic ether 
1 copolymer (Fig. 12d). SSEs with a vinylene carbonate (VC)/tetrahydrofurfuryl acrylate

2 molar ratio of 5:1 and $25 \mathrm{wt} \%$ LiTFSI have a higher ionic conductivity of $1.58 \times 10^{-4} \mathrm{~S}$

$3 \mathrm{~cm}^{-1}$ at ambient temperature than that of poly-VC (PVCA, Fig. 12e). Cyclic carbonate

4 segments in polymer-type SSEs provide high mechanical integrity, whereas cyclic ether

5 groups promote the dissociation of lithium salts and the formation of a stable solid

6 electrolyte interphase (SEI). Nag et al. ${ }^{104}$ prepared a high-ion-conducting polymer-type

$7 \quad$ SSE by using organoborane-modified polybenzimidazole (B-PBI) and IL, 1-butyl-3-

8 methylimidazolium bis(trifluoromethane-sulfonyl)imide (BMImTFSI, Fig. 12f).

9 Electrolytes with B-PBI/BMImTFSI (wt $\% / w t \%, 25 / 75)$ yield a conductivity of $8.8 \times$

$10 \quad 10^{-3} \mathrm{~S} \mathrm{~cm}^{-1}$. A Si|SSE|Li cell presents a reversible capacity of up to $1300 \mathrm{mAh} \mathrm{g}^{-1}$. Zhao

11 et al. ${ }^{186}$ created polymer-type SSE polyethylene oxide stabilized by the task-specific

12 trinal salt additives of $\mathrm{LiBOB}, \mathrm{LiNO}_{3}$, and LiTFSI (Fig. 12g). Li|SSE with a trinal salt

13 additive $\mid \mathrm{LiNi}_{1 / 3} \mathrm{Co}_{1 / 3} \mathrm{Mn}_{1 / 3} \mathrm{O}_{2}$ cell displays a capacity of $136.6 \mathrm{mAh} \mathrm{g}^{-1}$ at $0.1 \mathrm{C}$, with a

14 Coulombic efficiency of $99 \%$ after 60 cycles. 
(a)
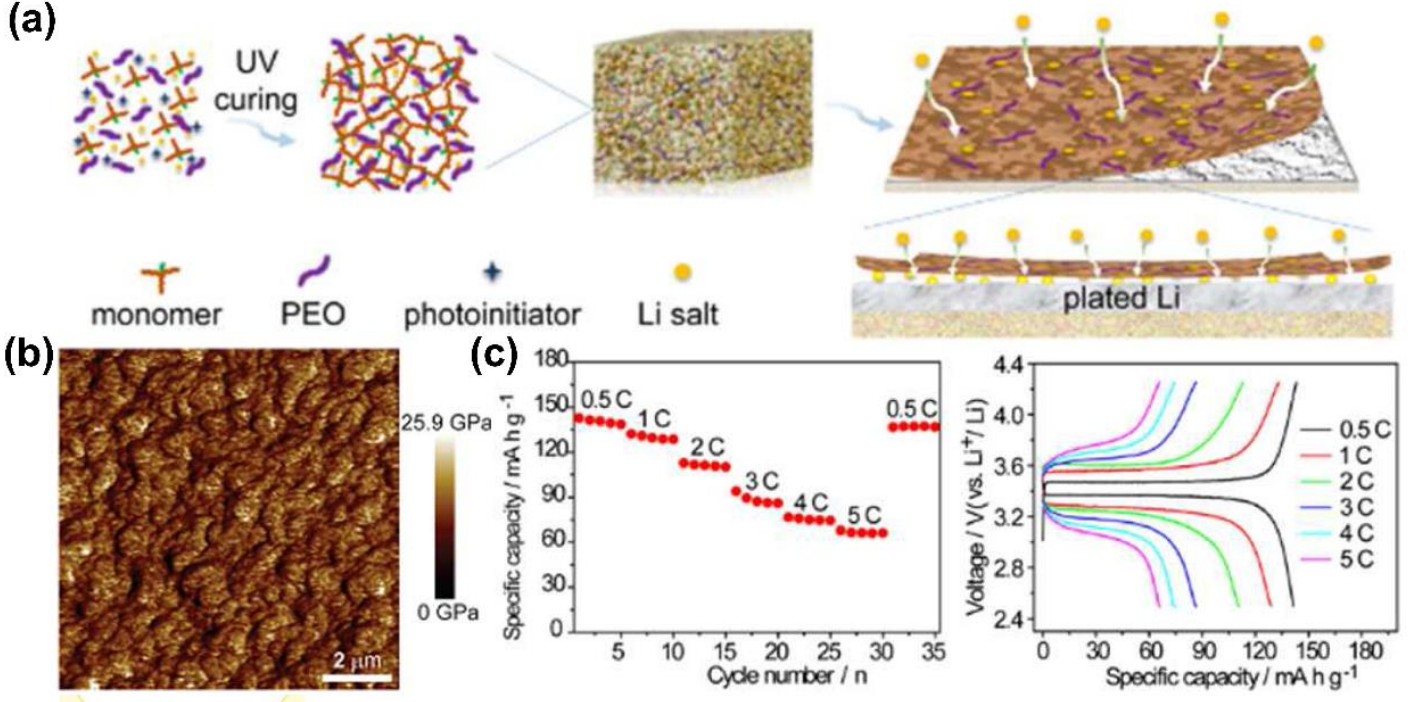

(d)

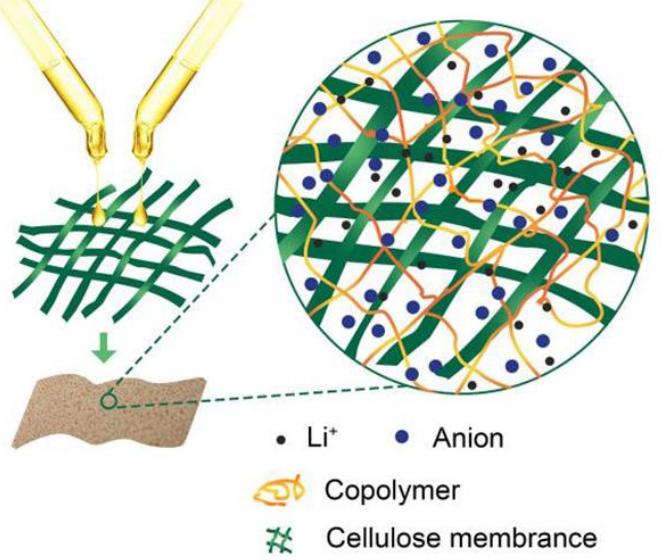

(e)

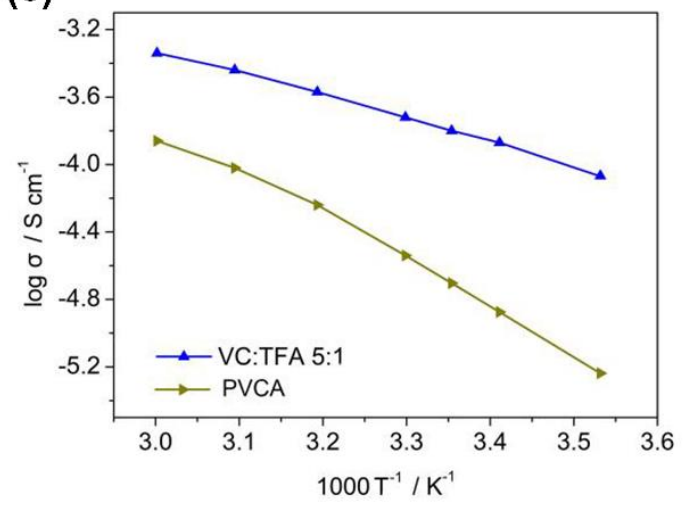

(f)

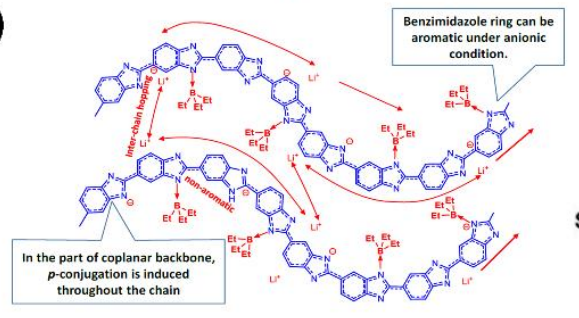

(g)

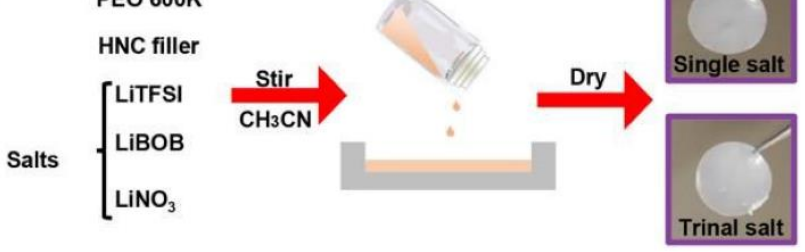

Fig. 12 (a) Illustration of the preparation of ipn-PEA electrolytes and the proposed

electrochemical deposition behavior of a Li metal with an ipn-PEA electrolyte. (b)

4 Young's modulus mapping of the ipn-PEA electrolyte. (c) Rate capabilities and corresponding galvanostatic discharge/charge voltage profiles of a Lilipn-

PEA $\mid \mathrm{LiFePO}_{4}$ cell (reproduced from Ref. ${ }^{103}$, with permission from the American

Chemical Society). (d) Schematic of solid polymer electrolytes based on a cyclic carbonate-cyclic ether copolymer. (e) Temperature-dependent ionic conductivity of 
1 SSEs (reproduced from Ref. ${ }^{102}$, with permission from Wiley). (f) Speculated

2 mechanism of lithium ion conduction in the system (reproduced from Ref. ${ }^{104}$, with

3 permission from the Royal Society of Chemistry). (g) Scheme of preparing

4 polyethylene oxide SSEs and the corresponding digital pictures of free-standing single

5 salt and trinal salt polymer SSE membrane (reproduced from Ref. ${ }^{186}$, with permission 6 from the Royal Society of Chemistry).

7

\subsubsection{Blending polymer-type SSEs}

Although the single polymer-type SSEs have been used as semicrystalline or amorphous host matrices for the preparation of organic SSEs, ${ }^{187-189}$ some issues have emerged due to the drawback of single polymer. ${ }^{59,107,190}$ For example, crystalline phase presenting in the polyethylene oxide materials reduces favourable ion conductive paths and results in low ionic conductivity; the brittleness of poly (methyl methacrylate) limits the fabrication of desirable shape, size, and flexibility for SSESDs. ${ }^{106,191}$ To address these shortcomings of single polymer-type SSEs, blending polymer-type SSE has been proposed to complement the properties between different polymers. Dhatarwal et al. ${ }^{106}$ prepared a blending polymer-type SSE of polyethylene oxide and poly (methyl methacrylate) blend $(50 / 50 \mathrm{wt} \%)$ with lithium tetrafluoroborate $\left(\mathrm{LiBF}_{4}\right)$ ionic salt, delivering an ionic conductivity of $10^{-6} \mathrm{~S} \mathrm{~cm}^{-1}$ at room temperature and an electrochemical window of 0 to $4.5 \mathrm{~V}$ due to the combination of good properties of polyethylene oxide and poly (methyl methacrylate).

Rathika et al. ${ }^{108}$ improved the ionic conductivity of polyethylene oxide-type SSEs 
$1 \quad\left(2.5 \times 10^{-4} \mathrm{~S} \mathrm{~cm}^{-1}\right.$ at room temperature) by adding $10 \mathrm{wt} \%$ poly (vinylidene difluoride)

2 to $90 \mathrm{wt} \%$ polyethylene oxide with $15 \mathrm{wt} \% \mathrm{Zn}\left(\mathrm{CF}_{3} \mathrm{SO}_{3}\right)_{2}$ (Fig. 13a). To improve the

3 ionic conductivity and thermal stability of a polyethylene oxide-type SSE for LIBs, Lim

4 et al. ${ }^{109}$ incorporated poly (methyl methacrylate) into polyethylene oxide matrix. The

5 blending polymer-type SSE with polyethylene oxide: poly (methyl methacrylate) $=8: 1$

6 exhibited the highest ionic conductivity of $1.35 \times 10^{-4} \mathrm{~S} \mathrm{~cm}^{-1}$ at room temperature

7 (from $10^{-8} \mathrm{~S} \mathrm{~cm}^{-1}$ ) and good mechanical stability because of the high specific surface

8 area and mesoporosity of the blending polymer-type SSE. Li et al. ${ }^{110}$ reported the

9 diethylethyletherylmethanamine bis(trifluoromethanesulfonyl)imide (DEEYTFSI) ionic liquid polymer electrolyte based on polyurethane acrylate (PUA)/poly(methyl

11 methacryltae) (PMMA) SSE. The optimized $19 \mathrm{wt} \%$ DEEYTFSI SSE exhibits good flexible (Fig. 13b), tensile properties (Fig. 13c), and smallest apparent activation energy

$21.1 \mathrm{~kJ} \mathrm{~mol}^{-1}$ and the highest ionic conductivity of $2.76 \times 10^{-4} \mathrm{~S} \mathrm{~cm}^{-1}$ at room temperature (Fig. 13d), together with a stable electrochemical window of $4.70 \mathrm{~V}(2.3$ to $7.0 \mathrm{~V}$, Fig. 13e) for lithium-ion battery among the studied $15 \mathrm{wt} \%$ and $21 \mathrm{wt} \%$ DEEYTFSI SSE samples. The coin-typed cell cycled at $0.1 \mathrm{C}$ retained $95 \%$ Coulombic efficiency on the 50th cycle, that is attributed to the combination of good properties of PUA and PMMA. Ma et al. ${ }^{111}$ prepared a blending polymer-type SSE, based on lithiumbis(trifluoromethanelsulfonyl) (LiTFSI), polyvinylidenedifluoride (PVDF) and polyvinyl alcohol (PVA) copolymer, achieving a high ionic conductivity up to $4.31 \times$

$2110^{-4} \mathrm{~S} \mathrm{~cm}^{-1}$ at room temperature. The electrochemical performance of the blending polymer-type SSE was evaluated in $\mathrm{Li}|\mathrm{SSE}| \mathrm{LiFePO}_{4}$ coin cell. Good performance with 
1 low capacity fading on charge-discharge cycling was achieved, and high specific

2 discharge capacity of $123 \mathrm{mAhg}^{-1}$ along with a Coulombic efficiency of $97.1 \%$ after

3100 cycles was retained. In future research, a design guideline needs to be established

4 to blend different polymers to achieve the tailored physicochemical properties.

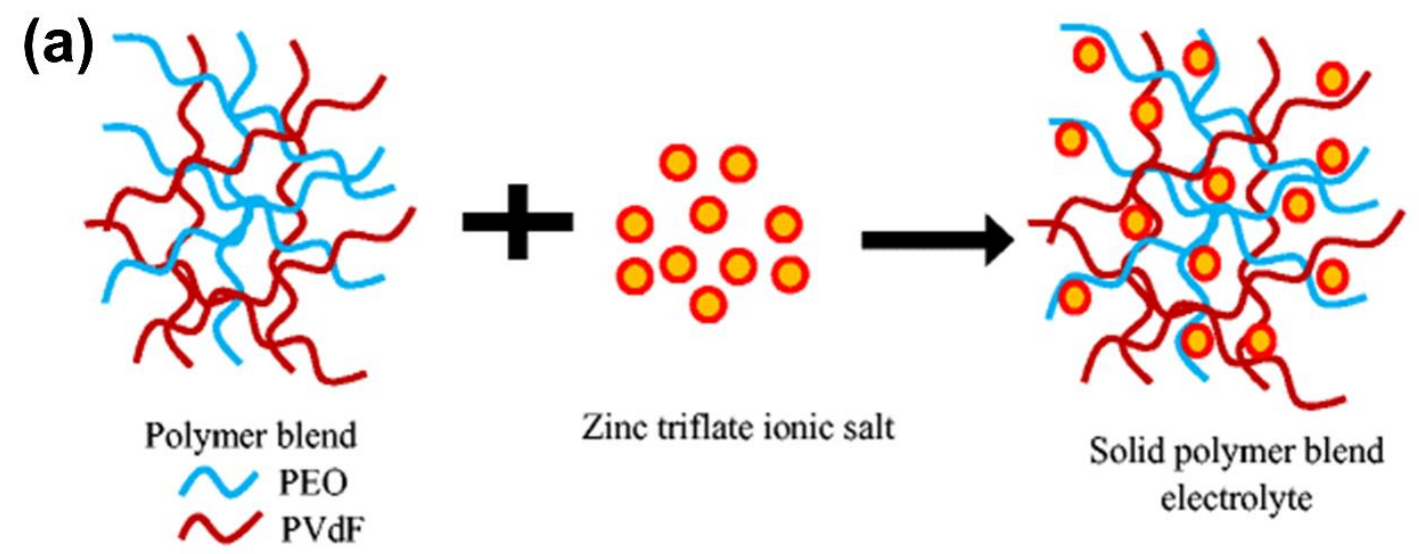

(b)

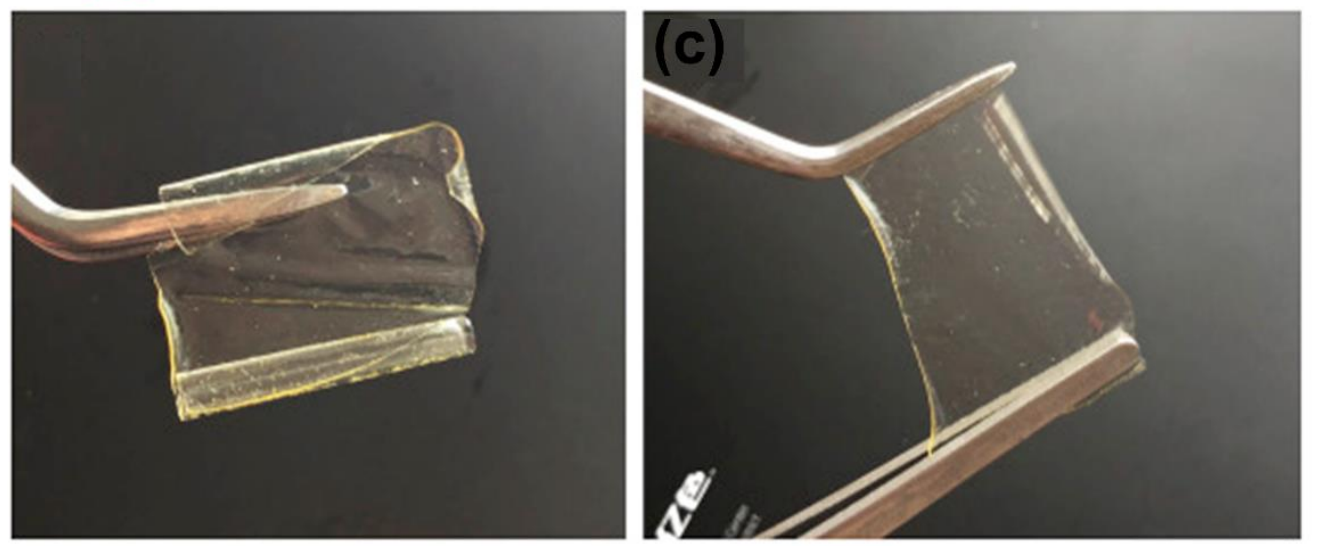

(d)
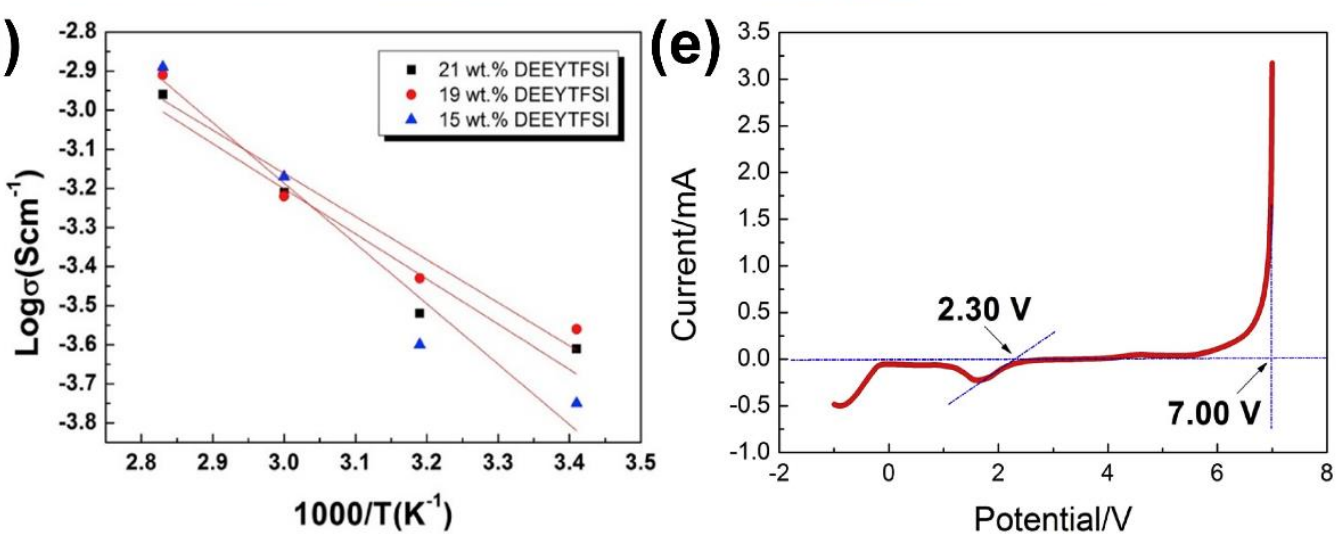

Fig. 13 (a) Schematic diagrams for the formation of SSE systems (reproduced from

7 Ref. ${ }^{108}$, with permission from the Springer). Photograph of SSE prepared by the

8 optimum concentration of 7 wt.\% LiTFSI, 19 wt.\% DEEYTFSI, 15 wt.\% PUA and 
159 wt.\% MMA: (b) flexible property; (c) tensile property. (d) Temperature-dependent

2 ionic conductivity of polymer electrolyte consists of different wt.\% of DEEYTFSI in

3 the range of $20-80{ }^{\circ} \mathrm{C}$. (e) Electrochemical stability window of $19 \mathrm{wt} . \%$

4 DEEYTFSI/7 wt.\% LiTFSI/15 wt.\% PUA/59 wt.\% PMMA electrolyte (reproduced 5 from Ref. ${ }^{110}$, with permission from the Elsevier). 
1 absorbability of liquid electrolyte, and further facilitate the migration of cations at the

2 electrode/electrolyte interface. As a result, such nano-sized oxide filled SSE can

3 provide high ionic conductivity of $1.27 \times 10^{-3} \mathrm{~S} \mathrm{~cm}^{-1}$ at room temperature, together

4 with enhanced electrochemical stability. Furthermore, the polymer with filling-type

5 SSE possesses a large electrochemical window from 0 to $5.3 \mathrm{~V}$ and superior thermal

6 stability up to $200{ }^{\circ} \mathrm{C}$. Recently, Choudhury et al. ${ }^{197}$ developed a mechanically roboust

7 hybrid electrolyte composed of hairy $\mathrm{SiO}_{2}$ grafted polyethylene oxide and

8 polypropylene oxide ( $\left.\mathrm{SiO}_{2}-\mathrm{PEO}-\mathrm{PPO}\right)$ as show in Fig. 14b. Such nanoparticle-polymer

9 electrolyte exhibits simultantously high mechanical modulus (1 MPa) and high ionic

10 conductivity $\left(5 \times 10^{-3} \mathrm{~S} \mathrm{~cm}^{-1}\right)$ at ambient temperature. $\mathrm{Li}\left|\mathrm{SiO}_{2}-\mathrm{PEO}-\mathrm{PPO}\right| \mathrm{LTO}$ cell

11 with PC/1 M LiTFSI liquid electrolyte salt exhibits prolong short circuit time and good cycling performance at $1 \mathrm{C}\left(0.50 \mathrm{~mA} \mathrm{~cm}^{-2}\right)$ compared to cells with other state-of-the-art polymer electrolytes (Fig. 14c). Suriyakumar et al. ${ }^{112}$ explored the aluminium terephthalic acid metal organic framework (Al-TPA-MOF) polymer with filling-type SSE based on a polyethylene oxide $(80$ wt $\%)$ network with lithium bis(trifluoromethane)sulfonimide (LiTFSI, $10 \mathrm{wt} \%$ ) and Al-TPA-MOF (10 wt\%). AlTPA-MOF was synthesized by an electrolytic process and dried under vacuum at $50{ }^{\circ} \mathrm{C}$ for 5 days; its structure is shown in Fig. 14d. This polymer-type SSE with filling of AlTPA-MOF, having an ionic conductivity of $1 \times 10^{-4} \mathrm{~S} \mathrm{~cm}^{-1}$ at $60{ }^{\circ} \mathrm{C}$ (Fig. 14e), is mechanically robust and thermally stable up to $270{ }^{\circ} \mathrm{C}$. Such high ionic conductivity

21 is attributed to the porous structure of Al-TPA-MOF that promoting a rapid ion transport.

The all-solid-state lithium sulfur cell delivers a specific capacity of $800 \mathrm{mAh} \mathrm{g}^{-1}$, and 
1 a stable performance upon prolonged cycling (50 cycles) even at $60{ }^{\circ} \mathrm{C}$.

(a)

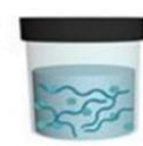

Polymer solution
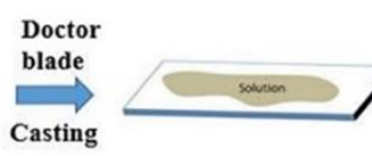
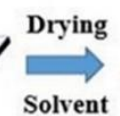
evaporation

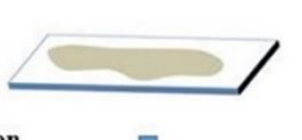

Peeling

Gel polymer electrolyte
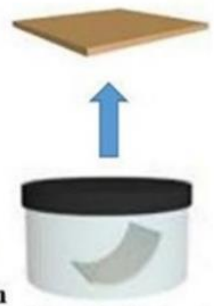

Liquid electrolyte

Immersion Composite
polymer membrane

(b)

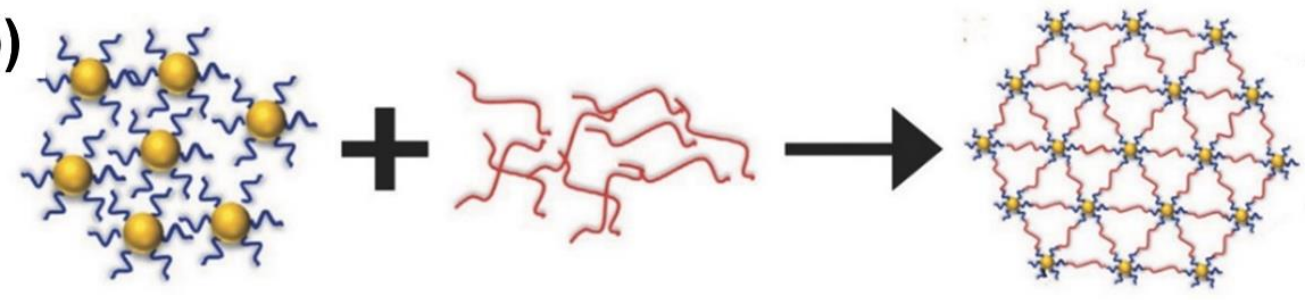

Silica ^ PEO oligomer ح PPO

(c)

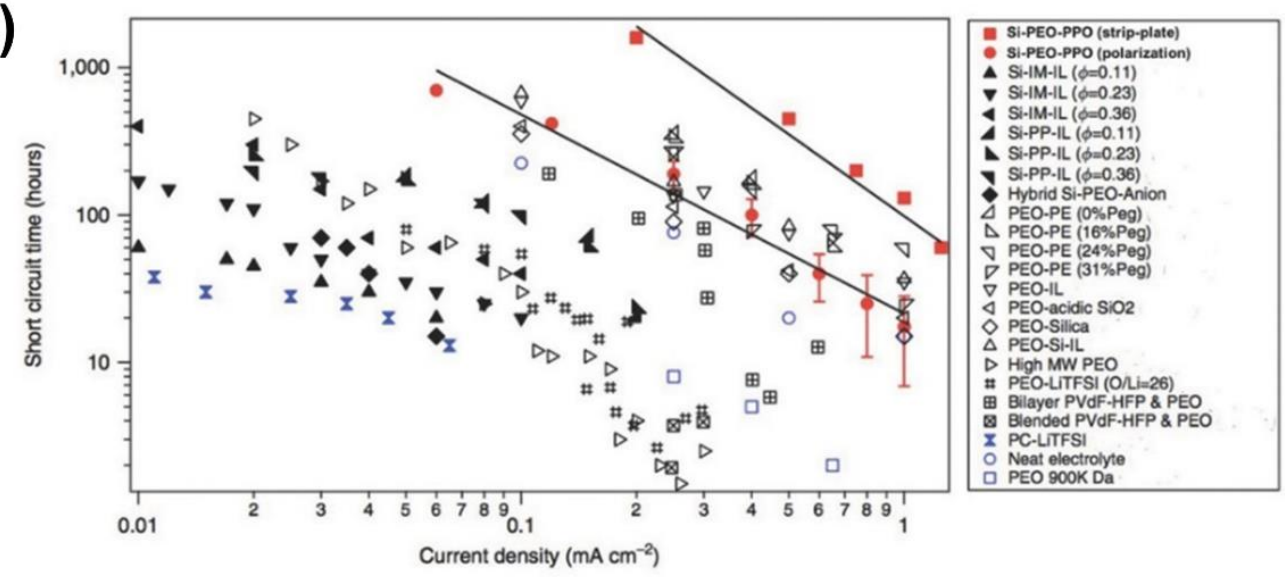

(d)

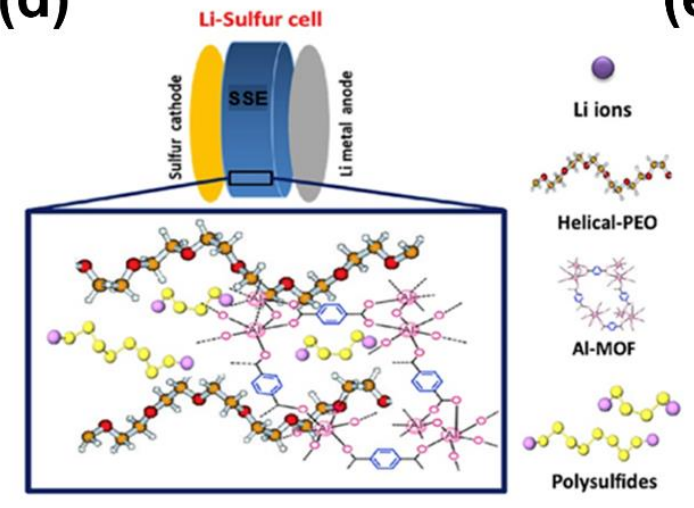

3 Fig. 14 (a) Schematic illustration of the preparation of the polymer with filling-type

4 SSE. (b) Schematic illustion of the synthesis of $\mathrm{SiO}_{2}$ nanoparticles tethered with (e)

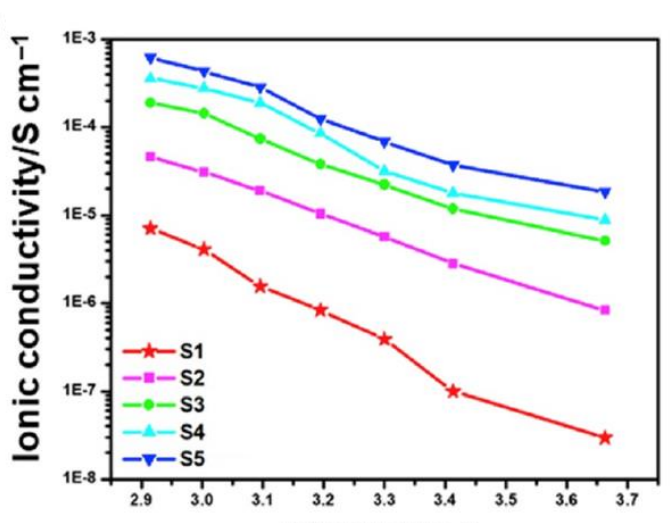

$(1000 / T) / K^{-1}$ 
1 hydroxy-terminated polyethylene oxide blended with polypropylene oxide $\left(\mathrm{SiO}_{2}-\mathrm{PEO}-\right.$

2 PPO) hybrid electrolyte. (c) Comparison of short circuit time of cells with $\mathrm{SiO}_{2}$-PEO-

3 PPO hybrid electrolyte and cells with state-of-the-art electrolytes (reproduced from

4 Ref. ${ }^{197}$, with permission from the Nature Publishing Group). (d) Sketched

5 representation of the polymer SSE with filling-type of Al-TPA-MOF in lithium sulfur

6 cell. (e) Arrhenius plot of the ionic conductivity as a function of the inverse temperature

7 (reproduced from Ref. ${ }^{112}$, with permission from the Elsevier).

\subsection{Hybrid SSEs}

Hybrid SSEs are emerging as a promising solution to achieving high ionic conductivity, optimal mechanical properties, and good safety for the development of high-performance SSESDs ${ }^{198}$ 199-201 . The common polymer hosts of composite polymer electrolytes are polyethylene oxide, polyacrylonitrile, poly(methyl methacrylate), and poly(vinyl chloride) $)^{1}$. Some active materials, such as $\mathrm{Li}_{1.5} \mathrm{Al}_{0.5} \mathrm{Ti}_{1.5}\left(\mathrm{PO}_{4}\right)_{3}{ }^{202}$ and $\mathrm{Li}_{6.75} \mathrm{La}_{3} \mathrm{Zr}_{1.75} \mathrm{Ta}_{0.25} \mathrm{O}_{12}{ }^{203}$, are dispersed or embedded in a polymer matrix to reinforce mechanical stability. The interaction of inorganic particles with polymer electrolytes not only increases the mechanical strength of polymers but also decrease the crystallization of polymers; thus, ion conductivity is enhanced ${ }^{204}$.

Xu et al. ${ }^{205}$ designed a hybrid SSE by using polyvinyl alcohol, polyethylene oxide, $\mathrm{KOH}$, and $\mathrm{Na}_{2} \mathrm{SnO}_{3}$ for a fiber-shaped solid-state aluminum-air battery. The obtained hybrid SSE improves the battery's stability and safety by reducing the corrosion of the aluminum anode. An $\mathrm{Al}|\mathrm{SSE}| \mathrm{Ag} @$ carbon nanotube cell displays a specific capacity of 
$1935 \mathrm{mAh} \mathrm{g}^{-1}$ at $0.5 \mathrm{~mA} \mathrm{~cm}{ }^{-2}$ and an energy density of $1168 \mathrm{Wh} \mathrm{kg}^{-1}$. Zhao et al. ${ }^{116}$

2 reported a hybrid $\mathrm{SSE} \mathrm{Li}_{10} \mathrm{GeP}_{2} \mathrm{~S}_{12}$ /polyethylene oxide for solid-state lithium batteries,

3 displaying an electrochemical window of $0-5.7 \mathrm{~V}$ and a lithium ionic conductivity of

$4 \quad 1.18 \times 10^{-5} \mathrm{~S} \mathrm{~cm}^{-1} . \mathrm{A} \mathrm{Li}|\mathrm{SSE}| \mathrm{LiFePO}_{4}$ cell exhibits a capacity retention of $92.5 \%$ after

550 cycles at $60^{\circ} \mathrm{C}$ and capacities of $158,148,138$, and $99 \mathrm{mAh} \mathrm{g}^{-1}$ at $0.1,0.2,0.5$, and

$61 \mathrm{C}$, respectively. Zhang et al. ${ }^{177}$ reported a hybrid $\mathrm{SSE} \mathrm{Li}_{7} \mathrm{La}_{3} \mathrm{Zr}_{2} \mathrm{O}_{12} /$ poly(vinylidene

7 fluoride-co-hexafluoropropylene) with a lithium ionic conductivity of $1.1 \times 10^{-4} \mathrm{~S}$

$8 \mathrm{~cm}^{-1}$ for high-performance solid-state lithium-ion batteries. A $\mathrm{Li}|\mathrm{SSE}| \mathrm{LiFePO} 4$ cell

9 exhibits an initial reversible discharge capacity of $120 \mathrm{~mA} \mathrm{~h} \mathrm{~g}^{-1}$ at $0.5 \mathrm{C}$ and a capacity

10 retention of $92.5 \%$ after 180 cycles.

11 Bae et al. ${ }^{206}$ investigated the ion transport mechanism in 3D nanostructured hybrid

$12 \mathrm{SSE} \mathrm{Li}_{0.35} \mathrm{La}_{0.55} \mathrm{TiO}_{3} /$ polyethylene oxide (Fig. 15a). The degree of percolation and the

13 interphase volume decrease, and a discontinuous lithium-ion conducting path is

14 generated by lowering the lithium-ion conductivity because of the agglomeration of

$15 \mathrm{Li}_{0.35} \mathrm{La}_{0.55} \mathrm{TiO}_{3}$ nanoparticles. The enhanced conductivity of the hybrid SSE with a

$16 \mathrm{Li}_{0.35} \mathrm{La}_{0.55} \mathrm{TiO}_{3}$ framework is attributed to a prepercolated $3 \mathrm{D}$ interconnected

$17 \mathrm{Li}_{0.35} \mathrm{La}_{0.55} \mathrm{TiO}_{3}$ network, thereby providing a continuous interphase, which serves as a

18 pathway for lithium-ion conduction. This study provides a theoretical guidance for the

19 design of hybrid SSEs. Chen et al. ${ }^{117}$ reported hybrid SSE

$20 \mathrm{Li}_{6.4} \mathrm{La}_{3} \mathrm{Zr}_{1.4} \mathrm{Ta}_{0.6} \mathrm{O}_{12} /$ polyethylene oxide with a lithium ionic conductivity of $>0.1 \times$

$21 \quad 10^{-3} \mathrm{~S} \mathrm{~cm}^{-1}$ (Fig. 15b) and demonstrated that the hybrid SSEs of "ceramic-in-polymer"

22 and "polymer-in-ceramic" can be applied to solid-state lithium batteries. The 
$1 \mathrm{Li}|\mathrm{SSE}| \mathrm{LiFePO}_{4}$ cell has a capacity of $139.1 \mathrm{mAh} \mathrm{g}^{-1}$, a retention of $93.6 \%$ after 100

2 cycles (Fig. 15c), a capacity retention of $103.6 \%$, and a Coulombic efficiency of $100 \%$

3 after 50 cycles (Fig. 15d) at $0.2 \mathrm{C}$ and $55^{\circ} \mathrm{C}$. Wang et al. ${ }^{119}$ designed a hybrid SSE

$4 \quad \mathrm{Li}_{1.5} \mathrm{Al}_{0.5} \mathrm{Ge}_{1.5}\left(\mathrm{PO}_{4}\right)_{3} /$ polyethylene oxide with an ionic conductivity of $1.67 \times 10^{-4} \mathrm{~S}$

$5 \mathrm{~cm}^{-1}$ (Fig. 15e) by using an ice template whose vertical $\mathrm{Li}_{1.5} \mathrm{Al}_{0.5} \mathrm{Ge}_{1.5}\left(\mathrm{PO}_{4}\right)_{3}$ walls

6 provide continuous channels for fast ionic transport, while a polyethylene oxide matrix

7 renders the composite electrolyte flexible. The viable approach involving an ice

8 template to fabricate hybrid SSEs with a high ionic conductivity has also been

9 demonstrated. Liang et al. ${ }^{121}$ reported a hybrid $\mathrm{SSE} \mathrm{Li}_{7} \mathrm{La}_{3} \mathrm{Zr}_{2} \mathrm{O}_{12} /$ poly(vinylidene

fluoride-co-hexafluoropropylene) with an ionic conductivity of $3.71 \times 10^{-4} \mathrm{~S} \mathrm{~cm}^{-1}$. A

$11 \mathrm{Li}|\mathrm{SSE}| \mathrm{LiFePO}_{4}$ cell presents a discharge capacity of $163.1 \mathrm{mAh} \mathrm{g}^{-1}$, with $83.8 \%$ capacity retention after 200 cycles at $0.2 \mathrm{C}$ (Fig. 15f). Zhang et al. ${ }^{122}$ fabricated a hybrid $\mathrm{SSE} \mathrm{Li}{ }_{6} \mathrm{PS}_{5} \mathrm{Cl} /$ polyethylene oxide with a lithium ionic conductivity of $\sim 1 \times 10^{-3} \mathrm{~S} \mathrm{~cm}^{-1}$ by adding $5 \mathrm{wt} \%$ polyethylene oxide into $\mathrm{Li}_{6} \mathrm{PSS}_{5} \mathrm{Cl}$ and verified that adding a suitable polymer content in ceramic particles can effectively inhibit interfacial reactions and lithium dendrite growth, thereby considerably improving the cycling performance of solid-state lithium batteries. Therefore, $\mathrm{Li}|\mathrm{SSE}| \mathrm{LiNi} 0.8 \mathrm{Co}{ }_{0.1} \mathrm{Mn}_{0.1} \mathrm{O}_{2}$ cells exhibit a capacity of $75.6 \mathrm{~mA} \mathrm{~h} \mathrm{~g}^{-1}$ and a capacity retention of $91 \%$ of $>200$ cycles at $0.05 \mathrm{C}$. Huo et al. ${ }^{118}$ developed a sandwich-type ceramic-in-polymer electrolyte (with 20 vol\% $200 \mathrm{~nm} \mathrm{Li}{ }_{6.4} \mathrm{La}_{3} \mathrm{Zr}_{1.4} \mathrm{Ta}_{0.6} \mathrm{O}_{12}$ particles and polyethylene oxide) that has an ionic conductivity of $1.6 \times 10^{-4} \mathrm{~S} \mathrm{~cm}^{-1}$. A Li|SSE $\mid \mathrm{LiFePO} 4$ cell (Fig. 15g) shows a discharge capacity of $118.6 \mathrm{mAh} \mathrm{g}^{-1}$, with a capacity retention of $82.4 \%$ after 200 cycles at 0.1 
1 C. At 0.2 and $0.5 \mathrm{C}$, this cell maintains the specific capacities of 95.7 and $63.2 \mathrm{mAh} \mathrm{g}^{-1}$,

2 respectively. This case points out that fabricating sandwich-type composite electrolytes

3 with hierarchical filler designs can be an effective strategy to achieve dendrite-free

4 batteries with high performance and high safety at room temperature.

Hybrid SSEs combine the advantages of inorganic and organic SSEs to provide a

6 good choice for the acquisition of high-performance SSESDs. At present, studies focus

7 on the combination and optimization of various inorganic and organic SSEs to improve

8 the properties of hybrid SSEs. Ultrathin and lightweight hybrid SSEs with high ionic

9 conductivity are desired to achieve energy density comparable with liquid electrolyte-

10 based cells ${ }^{181}$. The direct integration of an electrode with hybrid SSEs into SSESDs is

11 an important research direction, but their chemical and electrochemical

12 incompatibilities are still a challenge ${ }^{207}$.

(a)

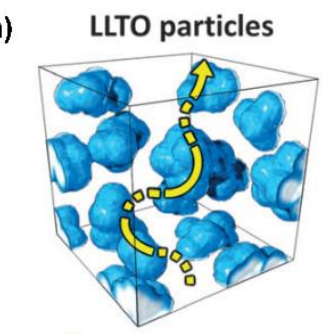

(b)

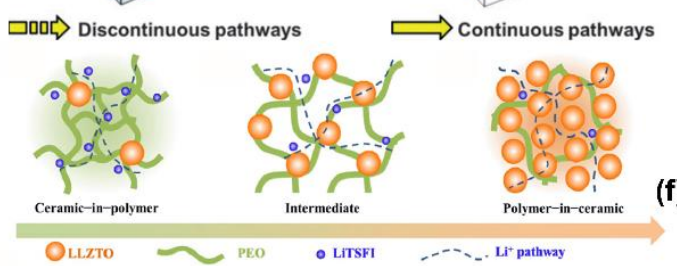

(c)
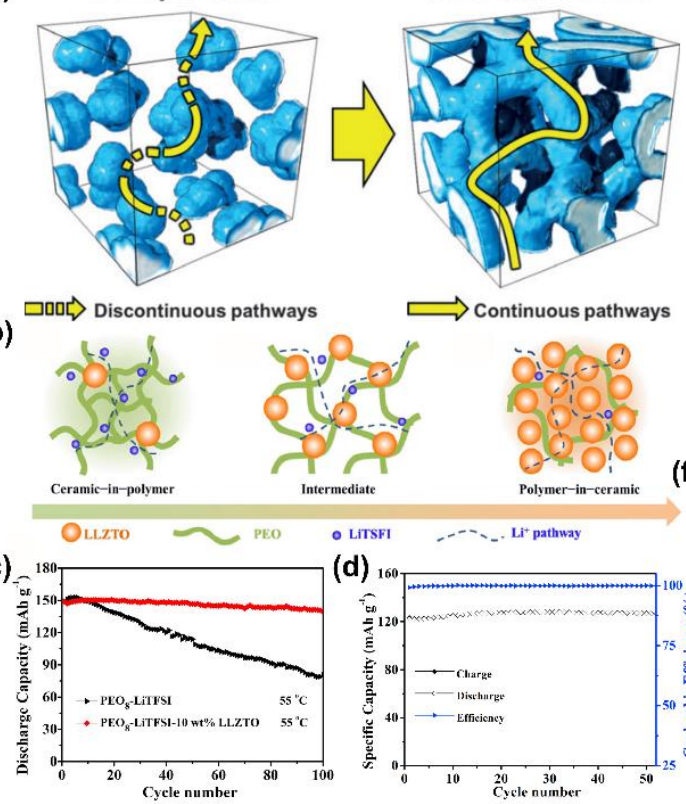

LLTO framework (e)

Growing Ice Crystal
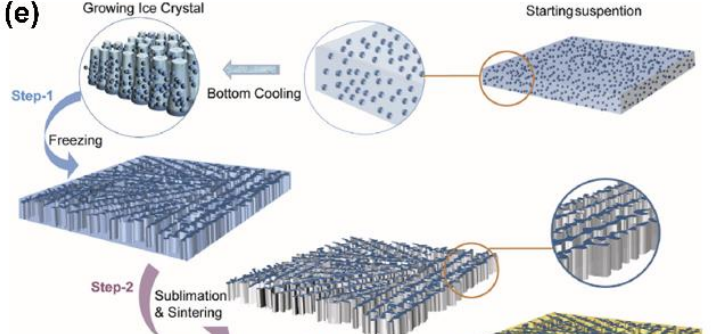

Step-3
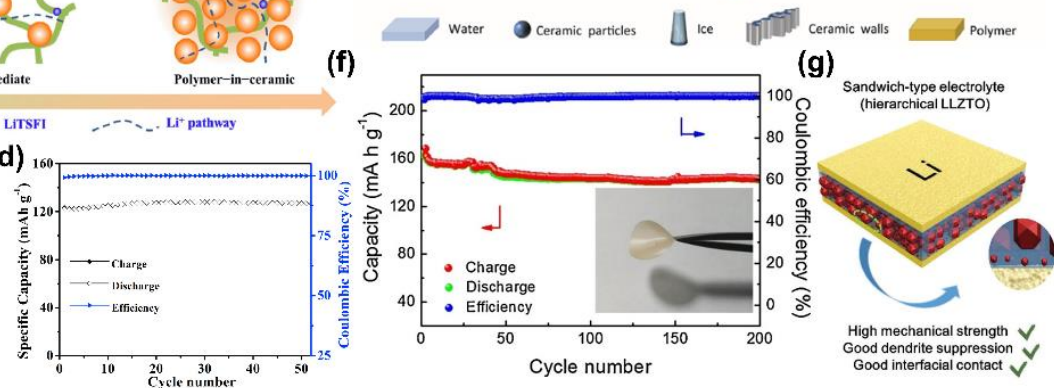

Fig. 15 (a) Schematic of the possible conduction mechanism in composite electrolytes

with agglomerated nanoparticles and a 3D continuous framework (reproduced from 
1 Ref. $^{206}$, with permission from Wiley). (b) Schematic of

$2 \quad \mathrm{Li}_{6.4} \mathrm{La}_{3} \mathrm{Zr}_{1.4} \mathrm{Ta}_{0.6} \mathrm{O}_{12} /$ polyethylene-oxide. (c) Cycling stability of Li|liquid

3 electrolyte $\mid \mathrm{LiFePO}_{4}$ and $\mathrm{Li}|\mathrm{SSE}| \mathrm{LiFePO}_{4}$ cells at $0.2 \mathrm{C}$ and $55{ }^{\circ} \mathrm{C}$. (d) Cycling

4 performance of the $\mathrm{Li}|\mathrm{SSE}| \mathrm{LiFePO} 4$ cell at $0.2 \mathrm{C}$ and $55^{\circ} \mathrm{C}$ (reproduced from Ref. ${ }^{117}$,

5 with permission from Elsevier). (e) Schematic of the preparation of ice-templated

$6 \mathrm{Li}_{1.5} \mathrm{Al}_{0.5} \mathrm{Ge}_{1.5}\left(\mathrm{PO}_{4}\right)_{3} /$ polyethylene oxide (reproduced from Ref. ${ }^{119}$, with permission

7 from Elsevier). (f) Cycling performance of a $\mathrm{Li}|\mathrm{SSE}| \mathrm{LiFePO}_{4}$ cell at a voltage of 2.4

$8 \quad 4.0 \mathrm{~V}$ at $0.2 \mathrm{C}$ in 200 cycles (reproduced from Ref. ${ }^{121}$, with permission from Elsevier).

9 (g) Schematic of hierarchical sandwich-type SSE (reproduced from Ref. ${ }^{118}$, with 10 permission from Wiley).

\section{Interfacial contact between electrodes and SSEs} conductivities. For inorganic SSEs, microstructure control, such as element doping, can significantly improve their ionic conductivity. For instance, $\mathrm{Li}_{7} \mathrm{P}_{3} \mathrm{~S}_{11}\left(3.2 \times 10^{-3} \mathrm{~S} \mathrm{~cm}^{-1}\right)$ is modified to $\mathrm{Li}_{9.54} \mathrm{Si}_{1.74} \mathrm{P}_{1.44} \mathrm{~S}_{11.7} \mathrm{Cl}_{0.3}\left(25 \times 10^{-3} \mathrm{~S} \mathrm{~cm}^{-1}\right)$ with $\mathrm{Si}$ and $\mathrm{Cl}$ dopants; $\operatorname{LiTi}_{2}\left(\mathrm{PO}_{4}\right)_{3}\left(3.8 \times 10^{-7} \mathrm{~S} \mathrm{~cm}^{-1}\right)$ is also modified to $\mathrm{Li}_{1.3} \mathrm{Al}_{0.3} \mathrm{Ti}_{1.7}\left(\mathrm{PO}_{4}\right)_{3}\left(6.2 \times 10^{-3} \mathrm{~S}\right.$ $\mathrm{cm}^{-1}$ ) with $\mathrm{Al}$ dopant ${ }^{91,127,208,209}$. However, a crucial challenge of SSE is reducing the high interfacial resistance between electrodes and SSEs in energy storage systems, and such high resistance is required for stable, reversible, and efficient electrochemical energy storage ${ }^{210}$. Recent research progress on SSESDs has shown that some strategies have been proposed to tackle the interfacial resistances between electrodes and SSEs, 
1 such as hybrid interface, interlayer interface, solid-liquid interface, quasi-solid-state 2 interface, and in-situ solidification interface (Table 2). 
Table 2 Electrochemical performance, device composition, and interfacial resistance of different solid-state energy storage devices with various interfaces.

\begin{tabular}{|c|c|c|c|c|c|c|c|c|c|c|}
\hline \multirow{2}{*}{$\begin{array}{c}\text { Interface } \\
\text { type }\end{array}$} & \multirow[t]{2}{*}{ Battery } & \multicolumn{3}{|c|}{ Device composition } & \multirow{2}{*}{$\begin{array}{l}\text { Interfacial resistance } \\
\text { reduction }(\Omega)\end{array}$} & \multirow{2}{*}{$\begin{array}{c}\text { Resistance } \\
\text { reduction } \\
\text { percentage (\%) }\end{array}$} & \multicolumn{3}{|c|}{ Electrochemical performance } & \multirow[t]{2}{*}{ Ref. } \\
\hline & & Anode & SSE & Cathode & & & $\begin{array}{c}\text { Specific capacity } \\
\left(\mathrm{mAh} \mathrm{g}^{-1}\right)\end{array}$ & Cycles & Rate & \\
\hline \multirow{3}{*}{$\begin{array}{l}\text { Hybrid } \\
\text { interface }\end{array}$} & Li battery & $\mathrm{Li}$ & $\mathrm{Li}_{7} \mathrm{P}_{3} \mathrm{~S}_{11}$ & $\mathrm{MoS}_{2} @ \mathrm{Li}_{7} \mathrm{P}_{3} \mathrm{~S}_{11}$ & $\sim 330$ to 225 (cathode) & $31.8(298.16 \mathrm{~K})$ & 547.1 & 400 & $0.1 \mathrm{C}$ & 211 \\
\hline & $\begin{array}{c}\text { Li-S } \\
\text { battery }\end{array}$ & $\mathrm{Li}$ & $\mathrm{Li}_{6} \mathrm{PS}_{5} \mathrm{Cl}$ & $\mathrm{Li}_{2} \mathrm{~S} @ \mathrm{Li}_{6} \mathrm{PS}_{5} \mathrm{Cl}$ & - & - & 830 & 60 & $50 \mathrm{~mA} \mathrm{~g}^{-1}$ & 9 \\
\hline & $\mathrm{Na}$ battery & $\mathrm{Na}_{15} \mathrm{Sn}_{4}$ & $\mathrm{Na}_{3} \mathrm{PS}_{4}$ & $\begin{array}{c}\mathrm{Na}_{4} \mathrm{C}_{6} \mathrm{O}_{6} @ \mathrm{Na}_{3} \mathrm{P} \\
\mathrm{S}_{4}\end{array}$ & $\sim 343$ to 109 (cathode) & $68.2(333.16 \mathrm{~K})$ & 184 & 400 & $0.2 \mathrm{C}$ & 17 \\
\hline \multirow{3}{*}{$\begin{array}{l}\text { Interlayer } \\
\text { interface }\end{array}$} & Li battery & $\mathrm{Li}$ & $\mathrm{Li}_{10} \mathrm{GeP}_{2} \mathrm{~S}_{12} / \mathrm{LiH}_{2} \mathrm{PO}_{4}$ & $\mathrm{LiCoO}_{2}$ & $\sim 5000$ to 2500 (anode) & $50(198.16 \mathrm{~K})$ & 131.1 & 500 & $0.1 \mathrm{C}$ & 212 \\
\hline & Na battery & $\mathrm{Na}$ & $\mathrm{Na}_{3} \mathrm{SbS}_{4} /$ polyethylene oxide & $\mathrm{Na}$ & $\sim 6000$ to 1500 (anode) & $75(333.16 \mathrm{~K})$ & - & 800 & $0.1 \mathrm{~mA} \mathrm{~cm}{ }^{-2}$ & 213 \\
\hline & Na battery & $\mathrm{Na}$ & $\mathrm{Na}_{3} \mathrm{Zr}_{2} \mathrm{Si}_{2} \mathrm{PO}_{12} / \mathrm{CPMEA}$ & $\mathrm{Na}$ & $\sim 4000$ to 1000 (anode) & $75(338.16 \mathrm{~K})$ & 102 & 70 & $0.2 \mathrm{C}$ & 18 \\
\hline \multirow[t]{4}{*}{$\begin{array}{l}\text { Solid-liquid } \\
\text { interface }\end{array}$} & Li battery & Li-In & $\mathrm{Li}_{6} \mathrm{PS}_{5} \mathrm{Cl}-\mathrm{LiTFSI}$ liquid & $\begin{array}{c}\mathrm{LiNi}_{0.6} \mathrm{Co}_{0.2} \mathrm{Mn}_{0} . \\
{ }_{2} \mathrm{O}_{2}\end{array}$ & $\begin{array}{l}\sim 14.8 \text { to } 10.4 \\
\text { (cathode) }\end{array}$ & $29.7(303.16 \mathrm{~K})$ & 172 & - & $0.025 \mathrm{C}$ & 19 \\
\hline & Li battery & $\mathrm{Li}$ & $\mathrm{Li}_{6} \mathrm{PS}_{5} \mathrm{Br}-\mathrm{LiPF}_{6}$ liquid & $\begin{array}{c}\mathrm{LiNi}_{1 / 3} \mathrm{Co}_{1 / 3} \mathrm{Mn}_{1} \\
{ }_{3} \mathrm{O}_{2} \\
\end{array}$ & - & - & 154 & 30 & $0.13 \mathrm{~mA} \mathrm{~cm}^{-2}$ & 214 \\
\hline & Li battery & $\begin{array}{c}\text { Carbon } \\
\text { nanotube }\end{array}$ & $\mathrm{Li}_{6} \mathrm{PS}_{5} \mathrm{Br}-\mathrm{LiPF}_{6}$ liquid & $\mathrm{Li}_{4} \mathrm{Ti}_{5} \mathrm{O}_{12}$ & - & - & 163 & 200 & $0.2 \mathrm{C}$ & 215 \\
\hline & Na battery & $\mathrm{Na}$ & $\mathrm{Na}_{3} \mathrm{Zr}_{2} \mathrm{Si}_{2} \mathrm{PO}_{12}-\mathrm{NaPF}_{6}$ liquid & $\mathrm{Na}_{3} \mathrm{~V}_{2}\left(\mathrm{PO}_{4}\right)_{3}$ & $\sim 1250$ to 55 (cathode) & $95.6(298.16 \mathrm{~K})$ & 90 & 10000 & $10 \mathrm{C}$ & 94 \\
\hline \multirow[t]{6}{*}{$\begin{array}{l}\text { Quasi-solid- } \\
\text { state interface }\end{array}$} & $\begin{array}{c}\mathrm{Li}-\mathrm{O}_{2} \\
\text { battery }\end{array}$ & $\mathrm{Li}$ & $\begin{array}{c}\text { Poly(vinylidene fluoride-co- } \\
\text { hexafluoropropylene)/LiTFSI gel }\end{array}$ & $\mathrm{O}_{2}$ & $\begin{array}{l}\sim 800 \text { to } 600 \text { (both } \\
\text { cathode and anode) }\end{array}$ & $25(298.16 \mathrm{~K})$ & - & 553 & $0.1 \mathrm{~mA} \mathrm{~cm}^{-2}$ & 216 \\
\hline & $\begin{array}{c}\text { Supercapac } \\
\text { itor }\end{array}$ & Carbon cloth & Polyvinyl alcohol/KOH gel & $\begin{array}{c}\mathrm{CuO} \text { supported } \\
\text { on } \mathrm{La}_{1-} \\
\mathrm{Sr}_{\mathrm{x}} \mathrm{CoO}_{3-\delta}\end{array}$ & $\begin{array}{l}\sim 3 \text { to } 1.5 \text { (both } \\
\text { cathode and anode) }\end{array}$ & $50(298.16 \mathrm{~K})$ & $1.26 \mathrm{~F} \mathrm{~cm}^{-2}$ & 3500 & $10 \mathrm{~mA} \mathrm{~cm}^{-2}$ & 217 \\
\hline & $\begin{array}{c}\mathrm{Li}-\mathrm{I} \\
\text { battery }\end{array}$ & $\mathrm{Li}$ & $\begin{array}{c}\text { Pentaerythritol- } \\
\text { tetraacrylate/LiTFSI gel }\end{array}$ & $\begin{array}{l}\text { MXene-based } \\
\text { iodine }\end{array}$ & $\begin{array}{l}\sim 180 \text { to } 82 \text { (both } \\
\text { cathode and anode) }\end{array}$ & $54.4(298.16 \mathrm{~K})$ & 330 & 1000 & $0.5 \mathrm{C}$ & 218 \\
\hline & $\begin{array}{c}\text { Li-S } \\
\text { battery }\end{array}$ & $\mathrm{Li}$ & $\begin{array}{c}\text { Trimethylolpropane triacrylate } \\
\text { polymer/LiTFSI gel }\end{array}$ & $\mathrm{S}$ & $\begin{array}{l}\sim 185 \text { to } 40 \text { (both } \\
\text { cathode and anode) }\end{array}$ & $79.5(298.16 \mathrm{~K})$ & 670 & 250 & $0.1 \mathrm{C}$ & 219 \\
\hline & $\begin{array}{l}\mathrm{Li}-\mathrm{CO}_{2} \\
\text { battery }\end{array}$ & $\mathrm{Li}$ & $\begin{array}{c}\text { Poly(vinylidene fluoride-co- } \\
\text { hexafluoropropylene)/LiTFSI gel }\end{array}$ & $\mathrm{CO}_{2}$ & - & - & $\sim 3.4$ & 40 & $0.08 \mathrm{~mA} \mathrm{~cm}^{-2}$ & 220 \\
\hline & $\begin{array}{c}\mathrm{Zn}-\mathrm{MnO}_{2} \\
\text { battery }\end{array}$ & $\mathrm{Zn}$ & $\begin{array}{c}\text { Polyvinyl alcohol//2nCl} / \mathrm{MnSO}_{4} \\
\text { gel }\end{array}$ & $\mathrm{MnO}_{2}$ & $\begin{array}{l}\sim 30 \text { to } 23 \text { (both } \\
\text { cathode and anode) }\end{array}$ & $23.3(298.16 \mathrm{~K})$ & 366.6 & 300 & $1110 \mathrm{~mA} \mathrm{~g}^{-1}$ & 221 \\
\hline In-situ & Li battery & $\mathrm{Li}$ & Poly-1,3-dioxolane/LiTFSI & $\mathrm{Li}$ & & $95.4(298.16 \mathrm{~K})$ & - & 300 & $1 \mathrm{~mA} \mathrm{~cm}^{-2}$ & 21 \\
\hline
\end{tabular}




2

\subsection{Hybrid interface between electrodes and SSEs}

To improve the interfacial contact and reduce the interfacial resistance of electrodes and SSEs in devices, researchers mixed electrode materials and SSE materials to form a hybrid interface sintered in an inert atmosphere. Chi et al ${ }^{17}$ designed a hybrid interface that is a mixture of cathode $\mathrm{Na}_{4} \mathrm{C}_{6} \mathrm{O}_{6}$ and $\mathrm{SSE} \mathrm{Na}_{3} \mathrm{PS}_{4}$ for a solidstate $\mathrm{Na}_{15} \mathrm{Sn}_{4}\left|\mathrm{Na}_{3} \mathrm{PS}_{4}\right| \mathrm{Na}_{4} \mathrm{C}_{6} \mathrm{O}_{6} @ \mathrm{Na}_{3} \mathrm{PS}_{4}$ cell, as shown in Fig. 16a. SEM images and energy-dispersive X-ray (EDX) spectra indicate the intimate contact between cathode materials and SSEs (Fig. 16b), thereby decreasing the interfacial resistance from $343 \Omega$ to $109 \Omega$ because of the increased interface contact. The $\mathrm{Na}_{15} \mathrm{Sn}_{4}\left|\mathrm{Na}_{3} \mathrm{PS}_{4}\right| \mathrm{Na}_{4} \mathrm{C}_{6} \mathrm{O}_{6} @ \mathrm{Na}_{3} \mathrm{PS}_{4}$ cell has a specific capacity of $184 \mathrm{mAh} \mathrm{g}{ }^{-1}$, a specific energy of $395 \mathrm{Wh} \mathrm{kg}^{-1}$, and a capacity retention of $76 \%$ after 100 cycles at 0.1 $\mathrm{C}$ and $70 \%$ after 400 cycles at 0.2 C. Han et al. ${ }^{9}$ designed the hybrid interface of Li2 $\mathrm{S} @ \mathrm{Li}_{6} \mathrm{PS}_{5} \mathrm{Cl}$ by dissolving $\mathrm{Li}_{2} \mathrm{~S}$ (cathode material), polyvinylpyrrolidone (carbon precursor), and $\mathrm{Li}_{6} \mathrm{PS}_{5} \mathrm{Cl}$ (SSE) in ethanol and by conducting coprecipitation and hightemperature carbonization (Fig. 16c). $\mathrm{Li}_{2} \mathrm{~S}$ cathode materials and $\mathrm{Li}_{6} \mathrm{PS}_{5} \mathrm{Cl} \mathrm{SSE}$ are uniformly confined in a carbon matrix, with distinct properties of lithium storage capability, mechanical reinforcement, and ionic and electronic conductivities. The $\mathrm{Li}\left|\mathrm{Li}_{6} \mathrm{PS}_{5} \mathrm{Cl}\right| \mathrm{Li}_{2} \mathrm{~S} @ \mathrm{Li}_{6} \mathrm{PS}_{5} \mathrm{Cl}$ cell achieves a reversible capacity of $830 \mathrm{mAh} \mathrm{g}^{-1}$ at 50 $\mathrm{mA} \mathrm{g}^{-1}$ for 60 cycles.

In addition to mixing and sintering, the direct coating of SSEs on an electrode surface is an effective way to form a hybrid interface to reduce the interfacial resistance between electrodes and SSEs. Xu et al. ${ }^{211}$ uniformly coated SSE $\mathrm{Li}_{7} \mathrm{P}_{3} \mathrm{~S}_{11}$, with an ionic 
1 conductivity of $2.0 \times 10^{-3} \mathrm{~S} \mathrm{~cm}^{-1}$, on $\mathrm{MoS}_{2}$ to form a MoS $@ @ \mathrm{Li}_{7} \mathrm{P}_{3} \mathrm{~S}_{11}$ interface (Fig.

2 16d) for solid-state $\mathrm{Li}\left|\mathrm{Li}_{7} \mathrm{P}_{3} \mathrm{~S}_{11}\right| \mathrm{MoS}_{2} @ \mathrm{Li}_{7} \mathrm{P}_{3} \mathrm{~S}_{11}$ cells that exhibit a reversible capacity

3 of $547.1 \mathrm{mAh} \mathrm{g}^{-1}$ at $0.1 \mathrm{C}$ and a capacity of $238.1 \mathrm{mAh} \mathrm{g}^{-1}$ after 400 cycles, with a

4 Coulombic efficiency of almost $100 \%$. Their interfacial resistance decreases from 330

5 to $225 \Omega$ (Fig. 16e). Wang et al. ${ }^{222}$ also evaluated a solid-state

$6 \mathrm{Li}|\mathrm{IL} / \mathrm{MOF}| \mathrm{LiFePO}_{4} @ \mathrm{IL} / \mathrm{MOF}$ cell, which exhibits an initial discharge capacity of 145

$7 \quad \mathrm{mAh} \mathrm{g}^{-1}$ and a capacity of $132 \mathrm{mAh} \mathrm{g}^{-1}$ after 100 cycles at $0.1 \mathrm{C}$ at a temperature range

8 of $-20^{\circ} \mathrm{C}$ to $150^{\circ} \mathrm{C}$. The unique interfacial contact between SSEs and active electrodes

9 due to an interfacial wettability effect of the nanoconfined guests, which create an

10 effective 3D lithium ionic conductive network throughout the whole battery, is a key

11 factor of the excellent performance of Li|IL/MOF|LiFePO4@IL/MOF cells. 
(a)

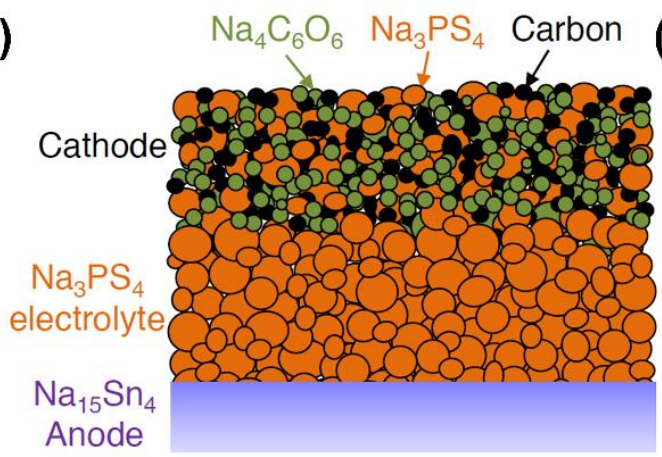

(b)

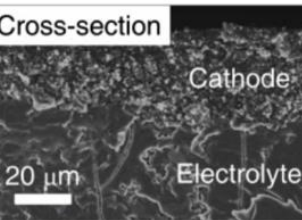

Surface
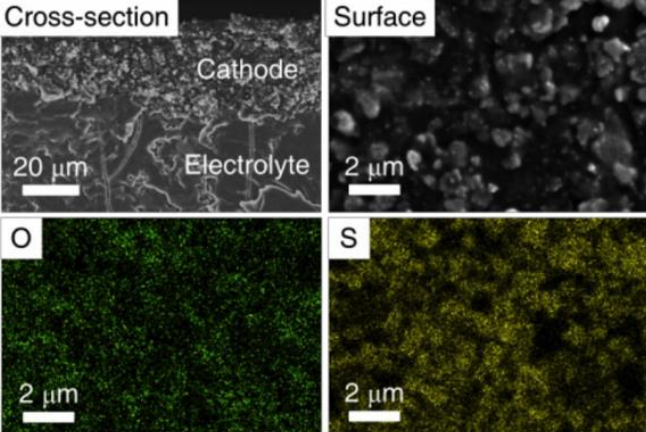

(c)
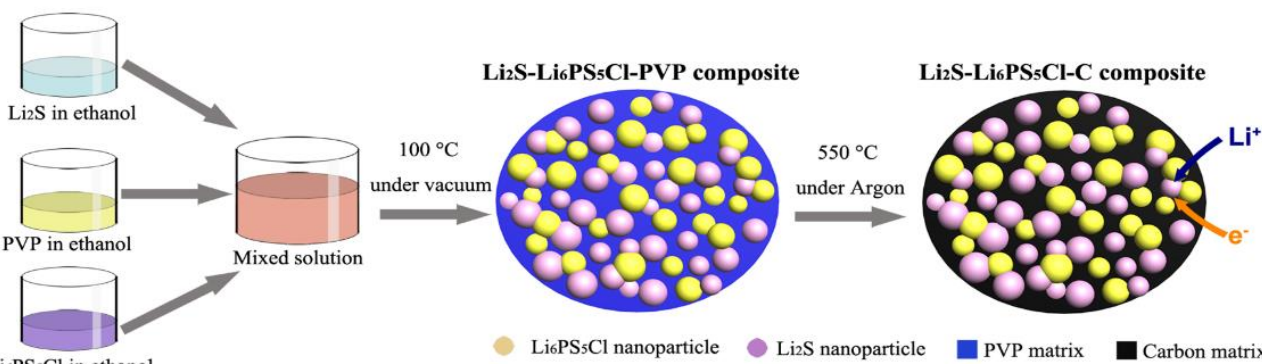

(d)

$\mathrm{Li}_{6} \mathrm{PS}_{5} \mathrm{Cl}$ in ethanol

$\mathrm{Li}_{6} \mathrm{PS}_{5} \mathrm{Cl}$ nanoparticle $\mathrm{Li}_{2} \mathrm{~S}$ nanoparticle

口 PVP matrix

(e)
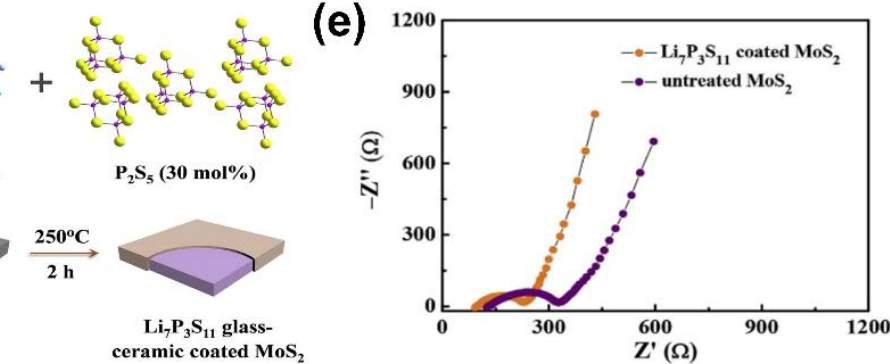

Fig. 16 (a) Schematic of a solid-state sodium battery. (b) SEM image of a

3 cathode/electrolyte cross-section (left top) and a cathode surface (right top) and the

4 corresponding EDX mapping of $\mathrm{O}$ and $\mathrm{S}$ (bottom; reproduced from Ref. ${ }^{17}$, with

5 permission from Wiley). (c) Schematic of the bottom-up synthesis of the mixed conducting $\mathrm{Li}_{2} \mathrm{~S}$ nanocomposites (reproduced from Ref. ${ }^{9}$, with permission from the

7 American Chemical Society). (d) Schematic of the preparation of $\mathrm{MoS}_{2} @ \mathrm{Li}_{7} \mathrm{P}_{3} \mathrm{~S}_{11}$ hybrid interface. (e) Nyquist plots of an all-solid-state cell with untreated $\mathrm{MoS}_{2}$ and $\mathrm{MoS}_{2} @ \mathrm{Li}_{7} \mathrm{P}_{3} \mathrm{~S}_{11}$ (reproduced from Ref. ${ }^{211}$, with permission from Elsevier).

\subsection{Interlayer interface between electrode and SSE}


1 mechanical connection between them, thereby providing another strategy for reducing

2 the interfacial resistance in devices ${ }^{223} 224,225$. Zhang et al. ${ }^{212}$ prepared an inorganic

$3 \quad \mathrm{LiH}_{2} \mathrm{PO}_{4}$ interlayer to circumvent the intrinsic chemical stability issues between SSE

$4 \mathrm{Li}_{10} \mathrm{GeP}_{2} \mathrm{~S}_{12}$ and anode lithium, such as the migration of mixed ionic-electronic

5 reactants to the inner part of $\mathrm{Li}_{10} \mathrm{GeP}_{2} \mathrm{~S}_{12}$ and the kinetically sluggish reactions in an

6 SSE/anode interface because of an increase in the connection between anode lithium

7 and $\mathrm{SSE} \mathrm{Li}_{10} \mathrm{GeP}_{2} \mathrm{~S}_{12}$ due to the $\mathrm{LiH}_{2} \mathrm{PO}_{4}$ interlayer (Fig. 17a). The optimized

$8 \mathrm{Li}\left|\mathrm{LiH}_{2} \mathrm{PO}_{4} / \mathrm{Li}_{10} \mathrm{GeP}_{2} \mathrm{~S}_{12}\right| \mathrm{LiCoO}_{2}$ cell, with a reduction in the interfacial resistance from

$95000 \Omega$ to $2500 \Omega$ (Fig. 17b), has a reversible discharge capacity of $131.1 \mathrm{mAh} \mathrm{g}^{-1}$ at

10 the initial cycle and $113.7 \mathrm{mAh} \mathrm{g}^{-1}$ at the 500th cycle under $0.1 \mathrm{C}$, with a retention of

$1186.7 \%$. Hu et al. ${ }^{213}$ demonstrated that an organic cellulose polyethylene oxide interlayer

12 can stabilize the interface of sodium $/ \mathrm{Na}_{3} \mathrm{SbS}_{4}$ and reduce the interfacial resistance from

$134000 \Omega$ to $1000 \Omega$ by suppressing the electron pathway of the $\mathrm{Na}_{3} \mathrm{SbS}_{4}$ decomposition

14 reaction (Fig. 17c). The $\mathrm{Na}$ (cellulose polyethylene oxide/ $\mathrm{Na}_{3} \mathrm{SbS}_{4} /$ cellulose

15 polyethylene oxide $\mid \mathrm{Na}$ cell shows a capacity of $102 \mathrm{mAh} \mathrm{g}^{-1}$ and a cycle life of 800

16 cycles at $0.1 \mathrm{~mA} \mathrm{~cm}^{-2}$ at $60{ }^{\circ} \mathrm{C}$.

17 Zhou et al. ${ }^{18}$ fabricated an interlayer between a metal sodium and SSE

$18 \mathrm{Na}_{3} \mathrm{Zr}_{2} \mathrm{Si}_{2} \mathrm{PO}_{12}$ through a heat treatment of sodium and the SSE in a cross-linked

19 poly(ethylene glycol) methyl ether acrylate (CPMEA, Fig. 17d), resulting in a uniform

20 sodium-ion flux across the interface, reducing the interfacial resistance from $4000 \Omega$ to

$21400 \Omega$, and suppressing unwanted dendrite formation. The

$22 \mathrm{Na}\left|\mathrm{CPMEA} / \mathrm{Na}_{3} \mathrm{Zr}_{2} \mathrm{Si}_{2} \mathrm{PO}_{12} / \mathrm{CPMEA}\right| \mathrm{NaTi}_{2}\left(\mathrm{PO}_{4}\right)_{3}$ cell shows a stable capacity of 102 
$1 \mathrm{mAh} \mathrm{g}^{-1}$ for 70 cycles at $0.2 \mathrm{C}$ at $65^{\circ} \mathrm{C}$, with a high Coulombic efficiency of $99.7 \%$.

2 Fan et al. ${ }^{226}$ produced a LiF interlayer between a lithium anode and a SSE $\mathrm{Li}_{3} \mathrm{PS}_{4}$

3 through IL LiFSI decomposition and deposition (Fig. 17e). The low electronic

4 conductivity and high electrochemical stability of LiF interlayer blocked the side

5 reactions between lithium and $\mathrm{Li}_{3} \mathrm{PS}_{4}$. The $\mathrm{Li}\left|\mathrm{LiF}_{2} / \mathrm{Li}_{3} \mathrm{PS}_{4}\right| \mathrm{LiCoO}_{2}$ cell has a capacity of

$6 \quad 120 \mathrm{mAh} \mathrm{g}^{-1}$ at $0.3 \mathrm{~mA} \mathrm{~cm}^{-2}$ between 3.5 and $3.8 \mathrm{~V}$, with a Coulombic efficiency

7 of $>99.8 \%$.

(a)
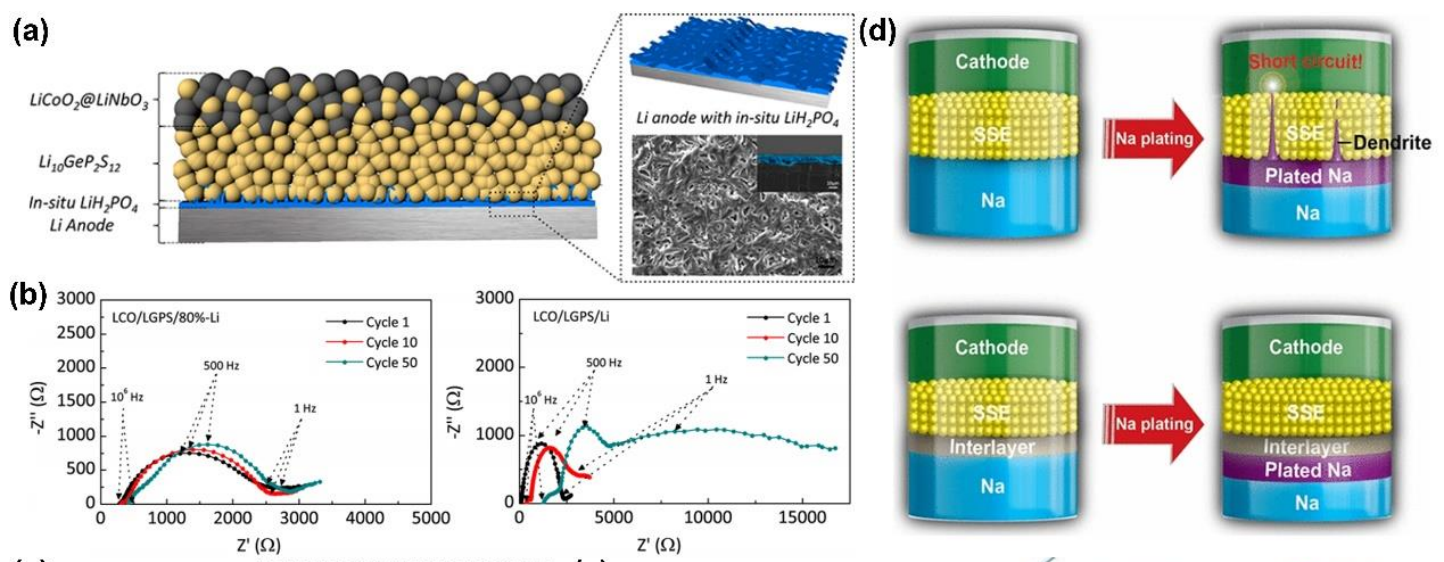

(c) symmetric cell/

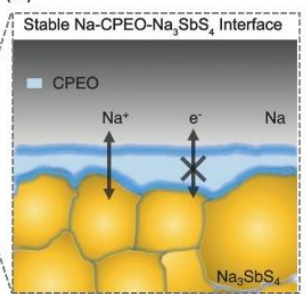

(e)
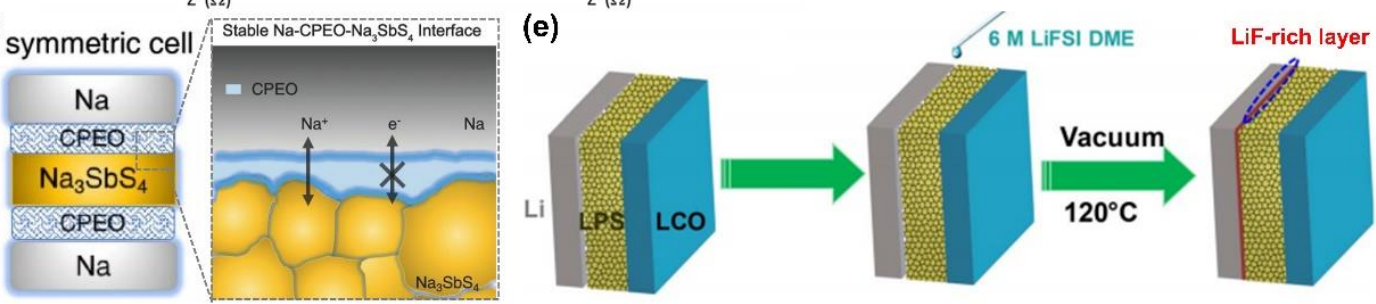

Fig. 17 (a) Schematic of the preparation of $\mathrm{LiH}_{2} \mathrm{PO}_{4}$ interlayer. (b) The EIS plots of

$\mathrm{Li}\left|\mathrm{Li}_{10} \mathrm{GeP}_{2} \mathrm{~S}_{12}\right| \mathrm{LiCoO}_{2}$ and $\mathrm{Li}\left|\mathrm{LiH}_{2} \mathrm{PO}_{4} / \mathrm{Li}_{10} \mathrm{GeP}_{2} \mathrm{~S}_{12}\right| \mathrm{LiCoO}_{2}$ cells at different cycles

11 (reproduced from Ref. ${ }^{212}$, with permission from the American Chemical Society). (c)

Cellulose polyethylene oxide interlayer between $\mathrm{SSE} \mathrm{Na}_{3} \mathrm{SbS}_{4}$ and sodium anode (reproduced from Ref. ${ }^{213}$, with permission from the American Chemical Society). (d)

Contact model of a solid electrolyte ceramic pellet and sodium metal, including a ceramic pellet with a poor wetting ability and an artificial interlayer with a good wetting 
1 ability during sodium plating (reproduced from Ref. ${ }^{18}$, with permission from the

2 American Chemical Society). (e) Interlayer between lithium metal and SSEs

3 (reproduced from Ref. ${ }^{226}$, with permission from the American Association for the

4 Advancement of Science).

\subsection{Solid-liquid interface between electrode and SSE}

The ionic conductivity of liquid electrolytes is much higher than that of SSEs. A solid-liquid interface refers to the addition of a small amount of liquid electrolytes between electrodes and SSEs, thereby serving as an effective medium for improving interface wettability and reducing interfacial resistance 227,228 . Zhang et al. ${ }^{94}$ enhanced the charge transfer rate at the $\mathrm{Na}_{3} \mathrm{~V}_{2}\left(\mathrm{PO}_{4}\right)_{3}$ cathode and $\mathrm{SSE} \mathrm{Na}_{3} \mathrm{Zr}_{2} \mathrm{Si}_{2} \mathrm{PO}_{12}$ interface through a small amount of nonflammable and nonvolatile IL $(0.8 \mathrm{M} \mathrm{NaPF} 6$ salt in ethylene carbonate-dimethyl carbonate, Fig. 18a). IL acts as a wetting agent, thereby enabling a favorable interface kinetics and reducing the interfacial resistance from 1250 $\Omega$ to $55 \Omega$ (Fig. 18b). The Na|SSE-IL $\mid \mathrm{Na}_{3} \mathrm{~V}_{2}\left(\mathrm{PO}_{4}\right)_{3}$ cell exhibited a specific capacity of $90 \mathrm{mAh} \mathrm{g}^{-1}$ after 10,000 cycles without capacity decay at $10.0 \mathrm{C}$. Oh et al. ${ }^{19}$ reported a scalable slurry fabrication protocol (Fig. 18c) to prepare IL-based polymeric binders (NBR-Li(G3)TFSI, NBR: nitrile-butadiene rubber, G3: triethylene glycol dimethyl ether, LiTFSI:lithium bis(trifluoromethanesulfonyl)imide) with $\mathrm{SSE} \mathrm{Li}_{6} \mathrm{PS}_{5} \mathrm{Cl}$, thereby eliminating undesirable side reactions or phase separation and reducing the interfacial resistance from $14.8 \Omega$ to $10.4 \Omega$. The capacity of a Li-In|Li6PS 5 Cl-NBR$\mathrm{Li}(\mathrm{G} 3) \mathrm{TFSI} \mid \mathrm{LiNi}_{0.6} \mathrm{Co}_{0.2} \mathrm{Mn}_{0.2} \mathrm{O}_{2}$ cell (Fig. 18d) at $0.025 \mathrm{C}$ is $172 \mathrm{mAh} \mathrm{g}^{-1}$, which is 
1 higher than that of a battery without the liquid interface $\left(131 \mathrm{mAh} \mathrm{g}^{-1}\right)$. Yubuchi et

2 al. $^{214}$ synthesized $\mathrm{SSE} \mathrm{Li}_{6} \mathrm{PSS}_{5} \mathrm{Br}$ from a homogeneous solution via a liquid-phase

3 technique. Fig. 18e shows the schematic of the infiltration process and the cross-

4 sectional SEM images of the infiltrated $\mathrm{LiNi}_{1 / 3} \mathrm{Mn}_{1 / 3} \mathrm{Co}_{1 / 3} \mathrm{O}_{2}$ electrodes before and after

5 pressing. $\quad \mathrm{Li}-\mathrm{In} \mid \mathrm{Li}_{6} \mathrm{PS}_{5} \mathrm{Br}-1 \quad \mathrm{M} \quad \mathrm{LiPF}_{6} \quad$ in ethylene carbonate and diethyl

6 carbonate $\mid \mathrm{LiNi}_{1 / 3} \mathrm{Mn}_{1 / 3} \mathrm{Co}_{1 / 3} \mathrm{O}_{2}$ cell exhibits a high reversible capacity of $154 \mathrm{mAh} \mathrm{g}^{-1}$

7 at $0.13 \mathrm{~mA} \mathrm{~cm}^{-2}$. Yubuchi et al. ${ }^{215}$ used an infiltration technique to make a solid-state

8 battery (carbon nanotube| $\mathrm{Li}_{6} \mathrm{PS}_{5} \mathrm{Br}-1 \mathrm{M} \mathrm{LiPF} 6$ in ethylene carbonate and diethyl

9 carbonate $\left.\mid \mathrm{Li}_{4} \mathrm{Ti}_{5} \mathrm{O}_{12}\right)$ that yields a capacity of $163 \mathrm{mAh} \mathrm{g}^{-1}$, with $88 \%$ retention for 500

10 cycles. extent by improving the contact and wettability between electrodes and SSEs, the stability of a solid-liquid electrolyte interface is still controversial. Busche et al. ${ }^{229}$ demonstrated that the ion conduction mechanism in two additional interfaces between 15 solid/liquid electrolytes and a resistive solid-liquid electrolyte interphase (SLEI) changes from the diffusion of solvated ions in liquid electrolytes to a hopping mechanism attributed to ion transport in solid electrolytes (Fig. 18f). The interface

18 between a fast-ion-conducting SSE and a conventional liquid electrolyte is chemically 19 unstable and forms a resistive SLEI. Weiss et al. ${ }^{230}$ also found that a highly resistive 20 solid-liquid electrolyte is formed between SSEs and liquid electrolytes, and this 21 formation cannot be slowed down or suppressed during cycling. 
(a)

(b)

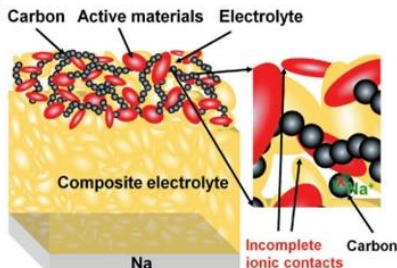

(b)

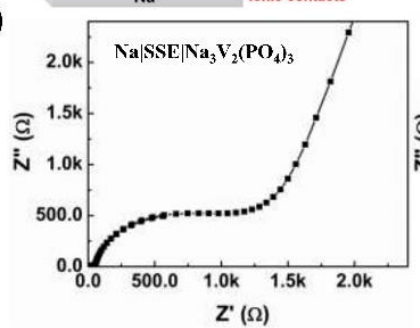

(e)

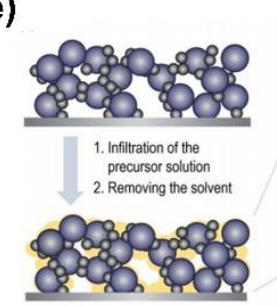

Pressing (360 MPa)

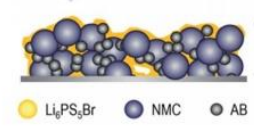

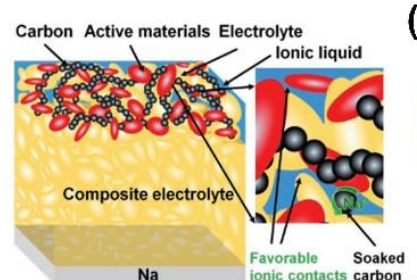

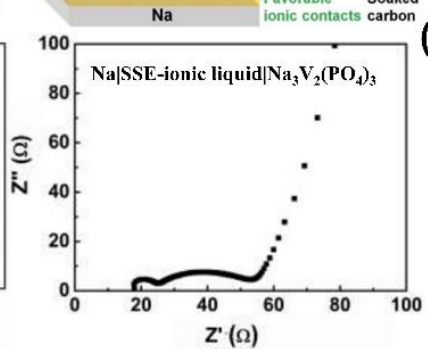

(f)

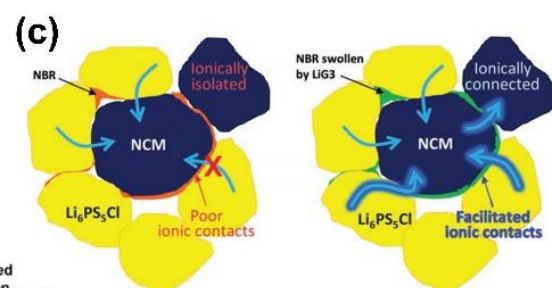

(d) Without LiG3

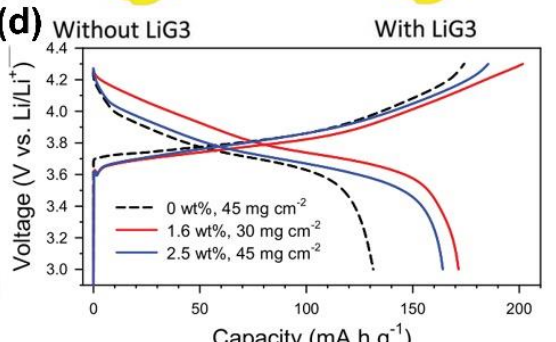

Capacity $\left(\mathrm{mA} \mathrm{h} \mathrm{g}^{-1}\right)$

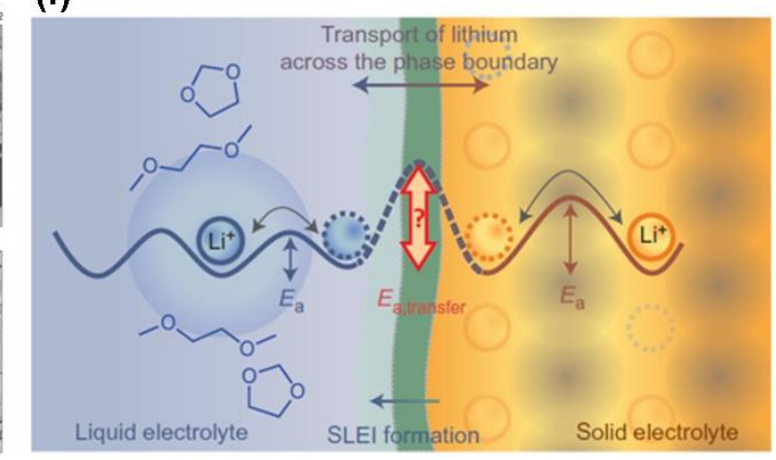

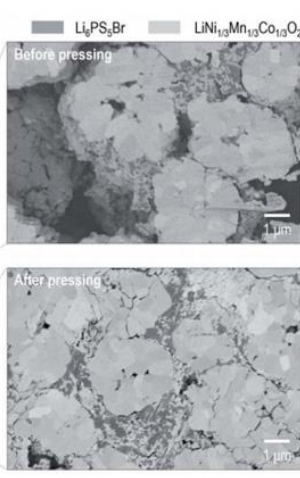

Fig. 18 (a) Schematic of $\mathrm{Na}|\mathrm{SSE}| \mathrm{Na}_{3} \mathrm{~V}_{2}\left(\mathrm{PO}_{4}\right)_{3}$ and $\mathrm{Na} \mid \mathrm{SSE}$-ionic liquid| $\mid \mathrm{Na}_{3} \mathrm{~V}_{2}\left(\mathrm{PO}_{4}\right)_{3}$

solid-state batteries. (b) Impedance spectrum of Na|SSE $\mid \mathrm{Na}_{3} \mathrm{~V}_{2}\left(\mathrm{PO}_{4}\right)_{3}$ and $\mathrm{Na} \mid \mathrm{SSE}-$ ionic liquid| $\mathrm{Na}_{3} \mathrm{~V}_{2}\left(\mathrm{PO}_{4}\right)_{3}$ solid-state battery (reproduced from Ref. ${ }^{94}$, with permission from Wiley). (c) Schematic of the microstructures of $\mathrm{LiNi}_{0.6} \mathrm{Co}_{0.2} \mathrm{Mn}_{0.2} \mathrm{O}_{2}$ (NCM) electrodes with and without LiG3. The highlighted blue arrows indicate $\mathrm{Li}^{+}$ionic pathways enabled by LiG3. (d) First-cycle charge-discharge voltage profiles of ultrathick $(\approx 200 \mu \mathrm{m}) \mathrm{LiNi}_{1 / 3} \mathrm{Mn}_{1 / 3} \mathrm{Co}_{1 / 3} \mathrm{O}_{2}$ electrodes with and without $\mathrm{LiG} 3$ (1.6 or 2.5 $\mathrm{wt} \%$ ) at $0.025 \mathrm{C}$ (reproduced from Ref. ${ }^{19}$, with permission from Wiley). (e) Schematic of the infiltration of a $\mathrm{LiNi}_{1 / 3} \mathrm{Mn}_{1 / 3} \mathrm{Co}_{1 / 3} \mathrm{O}_{2}$ porous electrode with $\mathrm{Li}_{6} \mathrm{PS}_{5} \mathrm{Br}$ via a liquidphase technique. Cross-sectional FE-SEM images of the infiltrated NMC electrode before (upper image) and after (bottom image) pressing (reproduced from Ref. ${ }^{214}$, with permission from the Royal Society of Chemistry). (f) Schematic of ion transport and 

$2 \quad$ Ref. $^{229}$, with permission from Nature).

3 capacity retention of $52.0 \%$ after 19 cycles.

resistance contributions in cells with solid-liquid phase boundaries (reproduced from

\subsection{Quasi-solid-state gel interface between electrodes and SSEs}

To tackle problems in the formation of SLEI in SSESDs, researchers proposed a quasi-solid-state interface between electrodes and SSEs. This interface refers to a gellike interface formed by an organic electrolyte between electrodes and SSEs ${ }^{217}$. Lei et al. ${ }^{231}$ fabricated a quasi-solid-state battery by introducing a SSE polyethylene oxide with soluble LiI as a cathode material, anthraquinone as an anode, and a nafion membrane as a separator (Fig. 19a). Solar energy can be converted and stored as chemical energy under light irradiation, which is further converted to electrical energy in the dark. The anthraquinone|SSE|LiI cell has a capacity retention of $86.3 \%$ after 30 cycles at $4 \mathrm{~mA} \mathrm{~g}^{-1}$, whereas the anthraquinone|liquid electrolyte|LiI cell shows a

Sun et al. $^{20}$ introduced a functional gel SSE (polyvinylidene fluoride-cohexafluoropropylene/cellulose acetate, grafted by sodium alginate) to increase the stability of $\mathrm{LiNi}_{0.88} \mathrm{Co}_{0.09} \mathrm{Al}_{0.03} \mathrm{O}_{2}$. An ion-conducting layer is formed on the interface between $\mathrm{LiNi}_{0.88} \mathrm{Co}_{0.09} \mathrm{Al}_{0.03} \mathrm{O}_{2}$ and a $\mathrm{SSE}$ through a chemical interaction between transition-metal cations of a $\mathrm{LiNi} 0.88 \mathrm{Co} 0.09 \mathrm{Al}_{0.03} \mathrm{O}_{2}$ cathode and a metalophilic reticulum group in sodium alginate (Fig. 19b). Hence, the interfacial compatibility on the cathode/electrolyte interface is enhanced, and the interfacial resistance decreases from $420 \Omega$ to $130 \Omega$ (Fig. $19 \mathrm{c}$ ). The $\mathrm{Li}|\mathrm{SSE}| \mathrm{LiNi}_{0.88} \mathrm{Co}_{0.09} \mathrm{Al}_{0.03} \mathrm{O}_{2}$ cell shows a capacity of 
$1204.9 \mathrm{mAh} \mathrm{g}^{-1}$ at a rate of $1.0 \mathrm{C}$ and a high discharge capacity retention of $68.33 \%$

2 within 300 cycles. Zeng et al. ${ }^{221}$ fabricated a quasi-solid-state $\mathrm{Zn}-\mathrm{MnO}_{2}$ battery by

3 utilizing a gel SSE polyvinyl alcohol $/ \mathrm{ZnCl}_{2} / \mathrm{MnSO}_{4}$. The $\mathrm{Zn} \mid$ polyvinyl

4 alcohol $/ \mathrm{ZnCl}_{2} / \mathrm{MnSO}_{4} \mid \mathrm{MnO}_{2}$ cell presents a reduced interfacial resistance of $23 \Omega$ (from

$530 \Omega$ ), a capacity of $366.6 \mathrm{mAh} \mathrm{g}^{-1}$ with a retention of $>77.7 \%$, and a Coulombic

6 efficiency of nearly $100 \%$ after 300 cycles. Zhao et al. ${ }^{216}$ used a gel SSE $\beta$-phase

7 poly(vinylidene fluoride-co-hexafluoropropylene) in a $\mathrm{Li}|\mathrm{SSE}| \mathrm{Ni}$ foam@ $\mathrm{Co}_{3} \mathrm{O}_{4}$ cell

8 that achieves a smaller interfacial resistance $(600 \Omega)$ and a long cycle life (203 cycles)

9 with a limited capacity of $0.1 \mathrm{mAh} \mathrm{cm}^{-2}$ at $0.1 \mathrm{~mA} \mathrm{~cm}^{-2}$ than the cell without a gel SSE

$10\left(\mathrm{Li}\left|\mathrm{LiClO}_{4}\right| \mathrm{Ni}\right.$ foam $@ \mathrm{Co}_{3} \mathrm{O}_{4}, 800 \Omega, 165$ cycles $)$.

11 The formation of a quasi-solid-state interface between electrodes and SSEs

12 depends on the type of gel SSEs that have good wettability and high plasticity. Tang et

13 al. ${ }^{218}$ developed a quasi-solid-state Li-I battery (a MXene-based iodine cathode and a

14 gel SSE made of $\mathrm{NaNO}_{3}$ particles dispersing in pentaerythritol tetraacrylate, Fig. 19d)

15 that simultaneously suppresses the diffusion of I species, stabilizes the Li anode/SSE

16 interface against dendrite growth, and reduces the interfacial resistance from $180 \Omega$

17 (without gel SSE) to $82 \Omega$, resulting in a stable capacity of $330 \mathrm{mAh} \mathrm{g}^{-1}$ at $0.5 \mathrm{C}$ for

181000 cycles.

19 Cho et al. ${ }^{219}$ demonstrated a monolithic heterojunction quasi-SSEs (MH-QEs)

20 based on thermodynamically immiscible dual phases of anodes (tetraethylene glycol

21 dimethyl ether)/cathodes (ethyl methyl sulfone). Driven by the combined effects of

22 structural uniqueness and thermodynamic immiscibility, electrode-customized $\mathrm{MH}-$ 
1 QEs provide an exceptional electrochemical performance that lies far beyond those

2 accessible with conventional batteries composed of 1,3-dioxalane (DOL)/1,2-

3 dimethoxyethane (DME) electrolytes. A Li|ethoxylated trimethylolpropane triacrylate

4 polymer|S cell has a capacity of $670 \mathrm{mAh} \mathrm{g}^{-1}$ and a Coulombic efficiency of $98.3 \%$

5 after 250 cycles at $0.1 \mathrm{C}$ because the interfacial resistance reduces from $185 \Omega$ (liquid

6 electrolyte) to $40 \Omega$ (Fig. 19e). Zhou et al. ${ }^{220}$ designed a quasi-solid-state fiber-shaped

$7 \quad \mathrm{Li}-\mathrm{CO}_{2}$ battery by using a gel SSE poly(vinylidene fluoride-co-hexafluoropropylene).

8 The $\mathrm{Li}|\mathrm{SSE}| \mathrm{Mo}_{2} \mathrm{C} /$ carbon nanotube cell achieves a charge potential of $<3.4 \mathrm{~V}$ and an

9 energy efficiency of $80 \%$ and can be reversibly discharged and charged for 40 cycles at

$10 \quad 0.08 \mathrm{~mA} \mathrm{~cm}^{-2}$ with $0.08 \mathrm{mAh} \mathrm{cm}^{-2}$. Yang et al. ${ }^{232}$ reported a flexible quasi-solid-state

11 microsupercapacitor based on free-standing black phosphorous thin films and gel SSE

12 polyvinyl alcohol/ $\mathrm{H}_{3} \mathrm{PO}_{4}$. The supercapacitor exhibits a capacity of $26.67 \mathrm{~F} \mathrm{~cm}^{-2}$ and a

13 capacity retention of $94.3 \%$ after 50,000 cycles at $500 \mathrm{~mA} \mathrm{~cm}^{-3}$. 

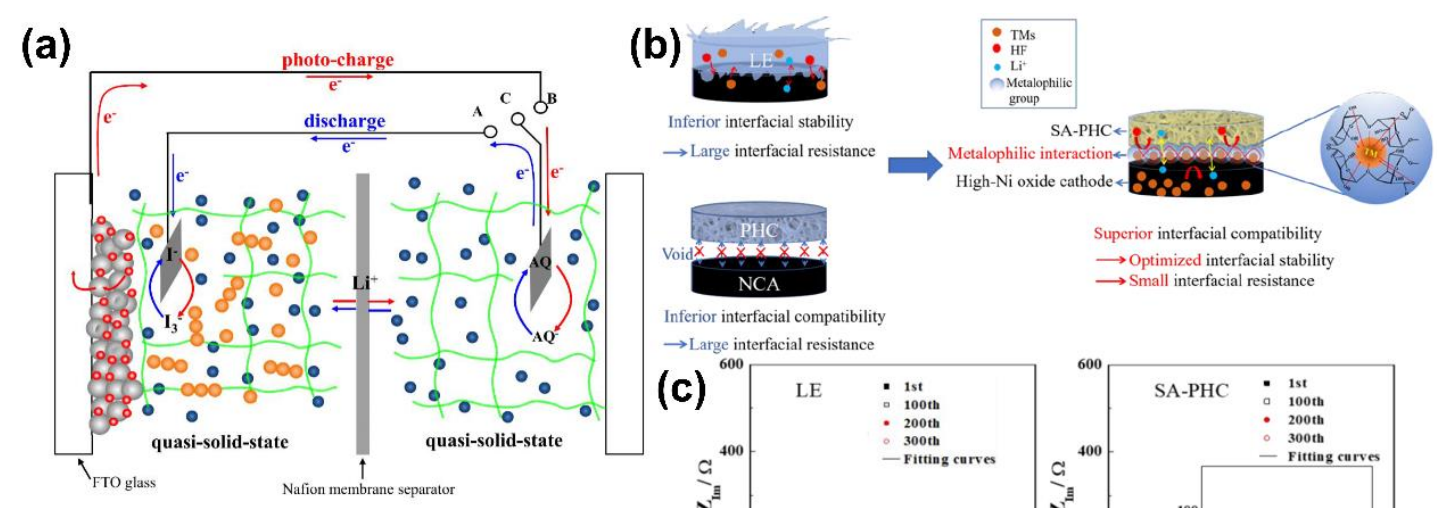

(d)
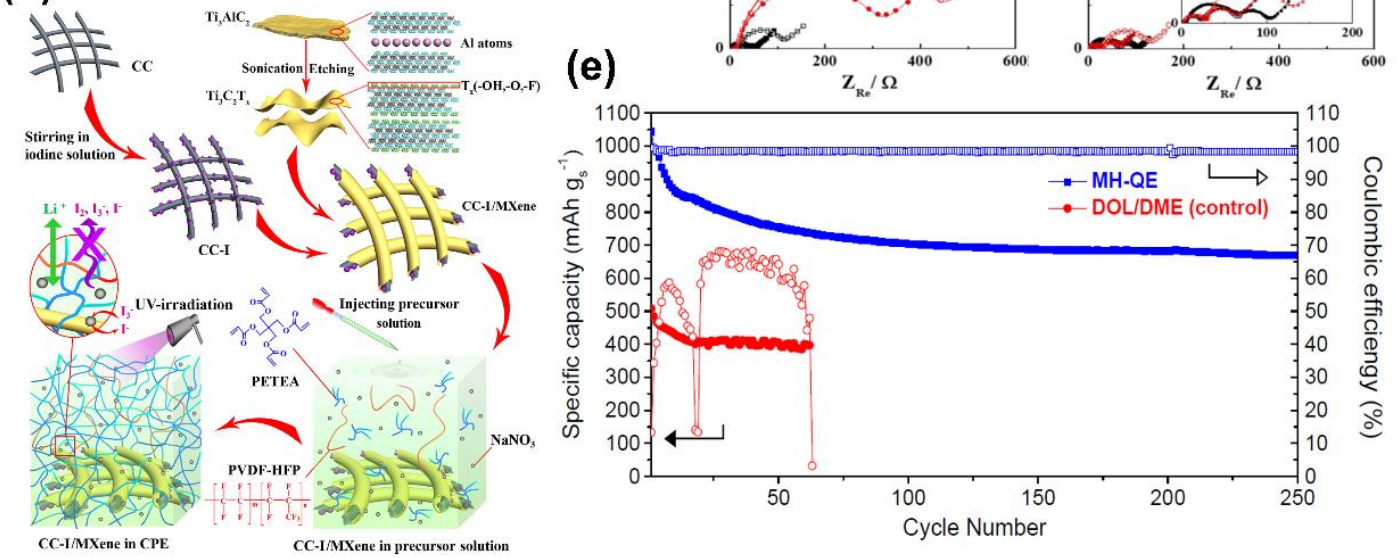

2 Fig. 19 (a) Configuration and electron transfer scheme of the designed quasi-solid-state

3 solar rechargeable battery with a gel SSE polyethylene oxide (reproduced from Ref. ${ }^{231}$,

4 with permission from the American Chemical Society). (b) Schematic of the functional

5 mechanism of SA-PHC. (c) EIS spectra of a cell with LE and SA-PHC after the selected

6 cycles (reproduced from Ref. ${ }^{20}$, with permission from the American Chemical Society).

7 (d) Schematic of the preparation of MXene-wrapped carbon cloth-iodine cathodes and

8 a composite polymer electrolyte (reproduced from Ref. ${ }^{218}$, with permission from the

9 American Chemical Society). (e) Cycling performance of cells with MH-QE and DOL/DME electrolytes at $0.1 \mathrm{C}$ (reproduced from Ref. ${ }^{219}$, with permission from the Royal Society of Chemistry). 
Although quasi-solid-state interfaces have good contact and wettability, can solve

2 interfacial problems, and can improve the electrochemical performance of SSESDs, the

3 poor mechanical contact properties of gel SSEs seriously affect the stability of energy

4 storage devices. Thus, the in situ solidification of SSEs to achieve a good interfacial

5 contact between electrodes become an effective approach in SSESD fabrication. Zhao

6 et al. ${ }^{21}$ used cationic aluminum species that initiate the ring-opening polymerization of

7 molecular ethers to produce polymer SSEs, thereby retaining the conformal interfacial

8 contact with electrodes (Fig. 20a). The SSE (polymerized DOL, poly-DOL) exhibits a

9 high ionic conductivity $\left(1 \times 10^{-3} \mathrm{~S} \mathrm{~cm}^{-1}\right)$ at room temperature. The Li|poly-DOL|Li cell

10 displays uniform lithium deposition and high lithium plating/striping efficiencies

11 of $>98 \%$ after 300 charge-discharge cycles at $1 \mathrm{~mA} \mathrm{~cm}^{-2}$ (Fig. 20b) and low interfacial

12 resistances (decreased from $6500 \Omega$ of ex situ polymer to $230 \Omega$ of poly-DOL, Fig. 20c).

13 A Li|poly-DOL $\mid \mathrm{LiFePO}_{4}$ cell with a capacity of $95 \mathrm{mAh} \mathrm{g}^{-1}$ and a Coulombic efficiency

14 of $99 \%$ for 700 cycles at $1.0 \mathrm{C}$ can be achieved with an in-situ solidification interface

15 (Fig. 20d). This study provides a promising direction for the in-situ solidification of

16 SSEs, thereby meeting the interfacial conductivity requirements for practical solid-state

17 polymer batteries. 
(a)
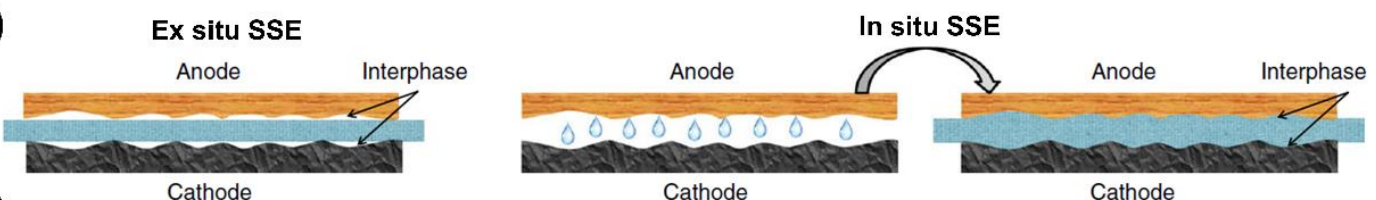

(b)

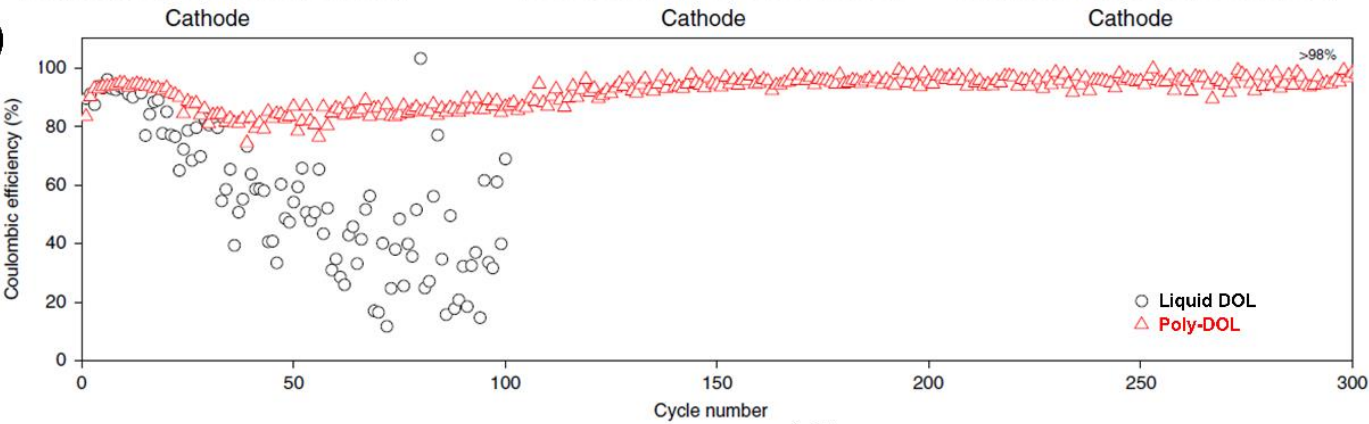

(c)

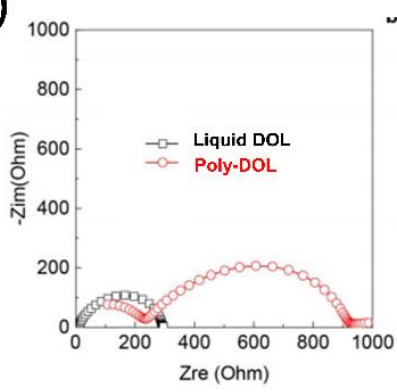

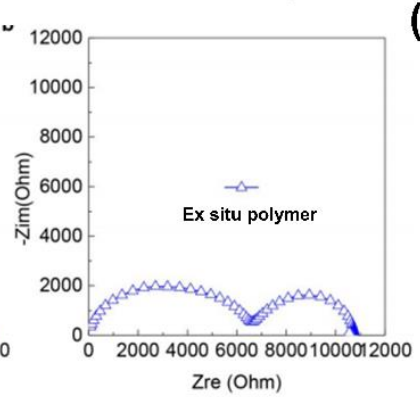

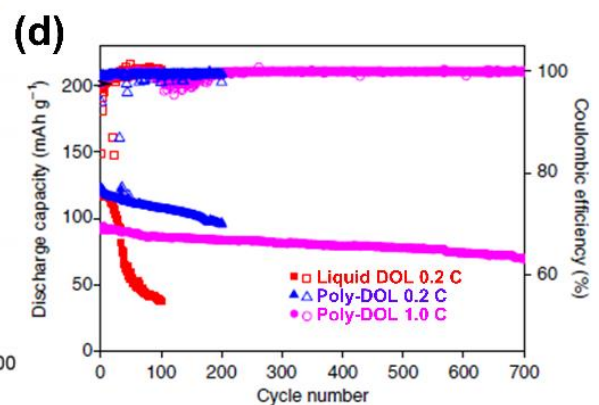

Fig. 20 (a) Schematic of ex-situ and in-situ syntheses of polymer SSEs. (b) Coulombic

efficiencies as a function of cycle number for liquid DOL and poly-DOL electrolyte. (c)

EIS of symmetrical Li cells with a liquid DOL electrolyte, a poly-DOL SSE, and an ex-

5 situ polymer. (d) Galvanostatic cycling performance and Coulombic efficiencies of Li|liquid DOL|LFP (red) and Li|poly-DOL|LFP cells (blue and purple; reproduced from Ref. ${ }^{21}$, with permission from Nature).

\section{Perspectives on SSESDs}

We provide our perspectives on the rational design of SSESDs based on SSE selections and approaches in reducing the interfacial resistance between electrodes and SSEs. 
SSEs are generally required to have a high ionic conductivity of $>1 \times 10^{-3} \mathrm{~S} \mathrm{~cm}^{-1}$.

2 Our previous study ${ }^{233}$ showed that NASICON-type SSE $\mathrm{Na}_{3} \mathrm{Zr}_{2} \mathrm{Si}_{2} \mathrm{PO}_{12}$ with an ionic

3 conductivity of $1.3 \times 10^{-3} \mathrm{~S} \mathrm{~cm}^{-1}$ delivers a high discharge voltage of $2.88 \mathrm{~V}$ and a low

4 voltage gap of $0.14 \mathrm{~V}$ at $0.1 \mathrm{~mA} \mathrm{~cm}^{-2}$ in hybrid sodium-air batteries. Quasi-solid-state

5 interfaces exhibit a superior electrochemical performance in supercapacitors because

6 of their good mechanical contact ${ }^{234-236}$. These two factors are discussed here in detail,

$7 \quad$ and directions for the development of SSEs and SSESDs are provided.

In SSESDs, SSEs not only separate positive and negative electrodes to prevent internal short circuit but also provide a channel for ion transmission between positive and negative electrodes. The bandgap of inorganic SSEs can be tuned by doping elements and constructing 3D ion transport channels, thereby accelerating ion transport performance in electrochemical processes. New inorganic SSEs, especially argyroditeand phosphate-type SSEs with a high ion conductivity, require further research. Organic SSEs with good flexibility can be the preferred electrolyte for flexible energy storage 
1 electrodes and SSEs and achieve the industrialization of high-performance SSESDs ${ }^{237}$,

$2 \quad 238$.

3

\section{$4 \quad 6.2$ Practical applications}

High-performance SSESDs have many applications, including smart grid systems,

6 EVs, electronic devices, and flexible and wearable devices, which may require a

7 particular method to assemble SSEs with electrodes. The proper selection of SSE for

8 each application is discussed below (Fig. 21).

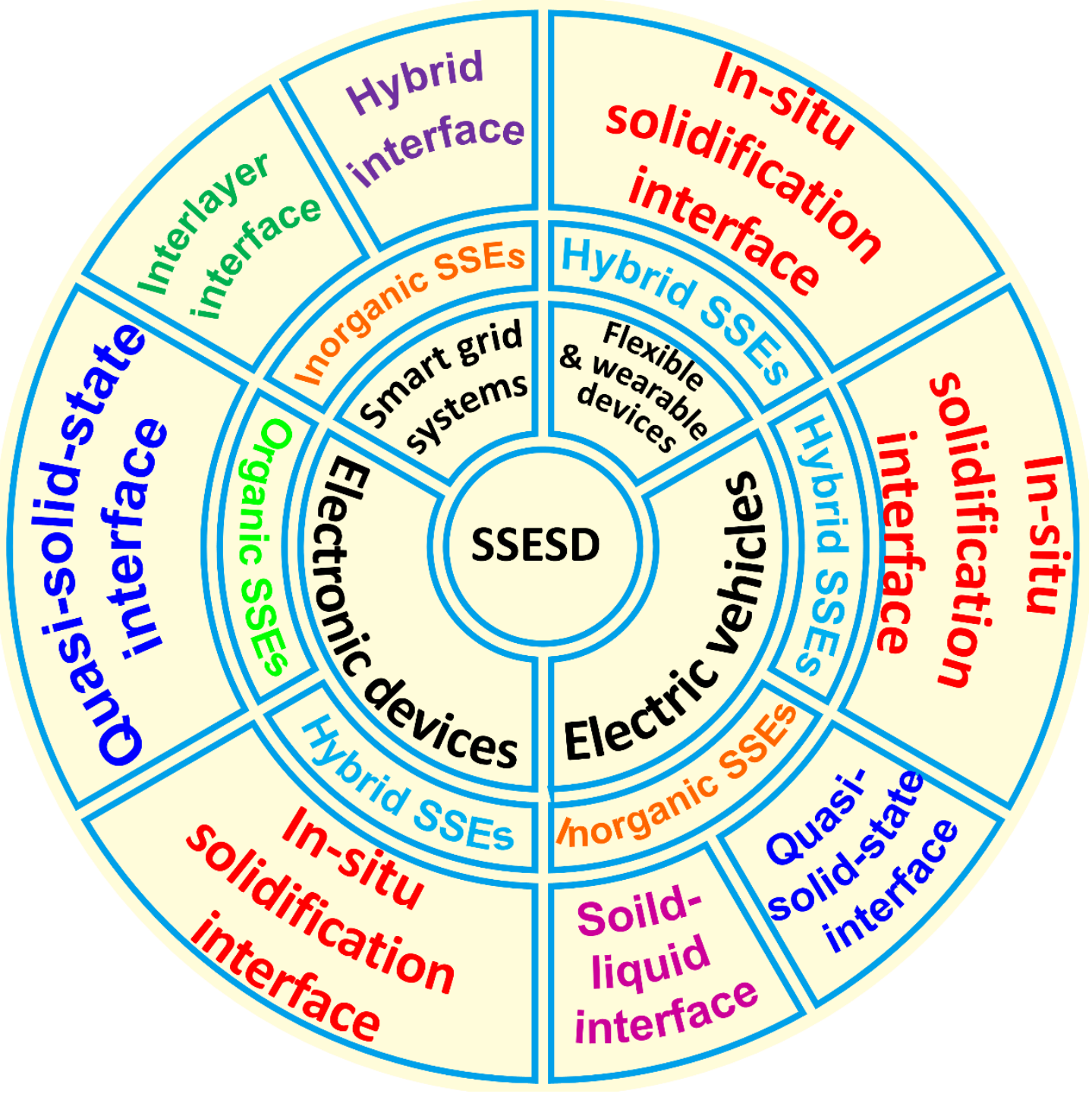


1 Fig. 21 Perspective: Design and configuration of high-performance SSESDs for

2 practical applications.

3

4

\subsubsection{Smart grid systems}

The application of energy storage devices in smart grid systems mainly includes backup power, energy storage from renewable energy sources, and grid frequency modulation $^{239}$. Backup powers should have excellent self-discharge performance, low cost, and high safety level ${ }^{240}$. Typical operating conditions are a small charge/discharge current rate $(0.5 \mathrm{C})$ and a large depth of discharge (100\%) in the application of energy storage from renewable energy sources ${ }^{241}$. Grid frequency modulation requires that an energy storage device can be under a large charge/discharge current rate $(1.0 \mathrm{C})$ and a small discharge depth $(45 \%-55 \%)^{242}$. Therefore, smart grid systems require SSESDs with sufficient stability and suitable rate performance. An inorganic SSE with a high ionic conductivity can be the first choice to meet these requirements because of its good aging resistance and structural stability. Hybrid or interlayer interfaces between SSEs and electrodes can be used to reduce interface resistance and meet the requirements of the large current discharge for grid frequency modulation. Thus, the ionic conductivity of energy storage devices and $\mathrm{C}$ rate performance are improved.

\subsubsection{EVs}

The sales of EVs reached $\sim 0.78$ million in $2017^{243}$, and their accumulated sales are projected to reach 5 million in $2020^{239}$. In addition to the requirements of high energy 
1 density and safety in charging and discharging, energy storage devices in EVs can

2 achieve a high power density ${ }^{244,245}$. Thus, a high ion conductivity of SSEs with good

3 mechanical strength is critically needed. Design options can be selected as follows: (1)

4 inorganic SSEs exhibiting a high ionic conductivity and a high mechanical strength and

5 combined with a solid-liquid interface or a quasi-solid-state interface, or (2) hybrid

6 SSEs that can be formed via in-situ solidification.

7

\subsubsection{Electronic devices}

SSESDs in portable electronic devices, such as cell phones and tablets, require a high ionic conductivity of SSEs for the fast charging rate of batteries ${ }^{246-248}$. Gel SSEs with a quasi-solid-state interface and hybrid SSEs that can be formed via in-situ solidification can be the choice for this application.

\subsubsection{Flexible and wearable devices}

Flexible and wearable electronic devices are often in intimate contact with the human body, thereby requiring electrolytes to have sufficient flexibility ${ }^{249}, 250$. Electrolyte leakage should be prevented even under extremely damaged conditions. In general, bracelets and watches do not require a large current discharge $(0.5 \mathrm{~A})$. Thus, the high ionic conductivity of SSEs may not be a major consideration ${ }^{251,252}$. A hybrid SSE with a "ceramic-in-polymer" structure ${ }^{178}$ that can be formed via in-situ solidification will be the focus of future research on flexible and wearable SSESDs. 


2

\section{Conclusion and outlooks}

Available commercial energy storage devices/systems cannot satisfy the increasing energy and power demands of electronic devices, EVs, and smart grid systems. Particularly, liquid electrolytes for energy storage devices suffer from inadequate electrochemical and thermal stabilities, low ion selectivity, poor safety, and even fire hazards. These problems may be efficiently resolved by replacing liquid electrolytes with SSEs. SSEs have potential for application in suppressing metal dendrite formation. However, the low ionic conductivity of SSEs and the high interface resistance between electrodes and SSEs have become the largest bottleneck that limits the developments of SSESDs. SSEs and SSESDs have been widely explored for electrochemical energy storage technologies and become new research directions because they can provide energy storage devices with enhanced safety and increased energy and power densities. In this review, various classes and features of SSEs, such as inorganic SSEs, organic SSEs, and hybrid SSEs, and interface designs in SSESDs, such as hybrid interface, interlayer interface, solid-liquid interface, quasi-solid-state interface, and in-situ solidification interface, are comprehensively reviewed, paving the way for the development of next-generation high-performance SSESDs. SSEs with distinct characteristics can be obtained, and various interfaces in energy storage devices can be designed, providing a rich selection for the preparation of SSESDs for various applications, such as smart grid systems, EVs, electronic devices, and flexible and wearable devices.

SSESDs are promising high-safety, high-energy, and high-power devices. Hybrid 
1 SSEs and in-situ solidification interfaces have been extensively investigated in the field

2 of energy storage. Many opportunities and challenges are still present in the research of

3 SSEs. Additional efforts are needed to further improve the mechanical strength and

4 ionic conductivity of SSEs, reduce interfacial resistance through interface modification

5 and design, and ensure the high power density and structural stability of SSESDs.

6 SSESDs should be developed as competitive technologies for energy storage and

$7 \quad$ solutions for various energy-related challenges.

8

9 Acknowledgement: This work was supported by the Doctoral Innovation Scholarship

10 of Beijing University of Technology, the Scholarship from the China Scholarship

11 Council of China (CSC No. 201806540025), the Scientific and Technological

12 Development Project of the Beijing Education Committee (No. KZ201710005009), the

13 Beijing Natural Science Foundation (L182008), the Science and Technology

14 Development Fund, Macau SAR (098/2015/A3, 191/2017/A3, 0041/2019/A1 and

$150046 / 2019 / \mathrm{AFJ}$ ), the Multi-Year Research Grants (MYRG2017-00216-FST and

16 MYRG2018-00192-IAPME) from the Research Services and Knowledge Transfer

17 Office at the University of Macau, and the UEA funding. Thanks to Ms. Pingping Jiao

18 of Jinan Publishing House for the image polishing. 


\section{References}

1. A. Manthiram, X. Yu and S. Wang, Nat. Rev. Mater, 2017, $2,16103$.

2. X. Xu, H. Wang, Y. Xie, J. Liu, H. Yan and W. Liu, J. Electrochem. Soc., 2018, 165, A2978-A2984.

3. X. Xu, J. Liu, Q. Zhang and H. Wang, Mater. Lett., 2019, 247, 29-31.

4. Y. S. Hu, Nat. Energy, 2016, 1, 16042.

5. X. Xu, Z. Hao, H. Wang, Y. Xie, J. Liu and H. Yan, J. Mater. Sci-Mater. Electron., 2018, 29, 16630-16638.

6. X. Xu, C. Qi, Z. Hao, H. Wang, J. Jiu, J. Liu, H. Yan and K. Suganuma, NanoMicro Lett., 2018, 10, 1.

7. E. Quartarone and P. Mustarelli, Chem. Soc. Rev., 2011, 40, 2525-2540.

8. J. Li, C. Ma, M. Chi, C. Liang and N. J. Dudney, Adv. Energy Mater, 2015, 5, 1401408.

9. F. Han, J. Yue, X. Fan, T. Gao, C. Luo, Z. Ma, L. Suo and C. Wang, Nano Lett., 2016, 16, 4521-4527.

10. R. C. Xu, X. H. Xia, S. H. Li, S. Z. Zhang, X. L. Wang and J. P. Tu, J. Mater. Chem. A, 2017, 5, 6310-6317.

11. L. Yue, J. Ma, J. Zhang, J. Zhao, S. Dong, Z. Liu, G. Cui and L. Chen, Energy Storage Mater, 2016, 5, 139-164.

12. N. W. Li, Y. Shi, Y. X. Yin, X. X. Zeng, J. Y. Li, C. J. Li, L. J. Wan, R. Wen and Y. G. Guo, Angew. Chem., 2018, 57, 1505-1509.

13. X. Zhang, X. G. Wang, Z. Xie and Z. Zhou, Green Energy Environ., 2016, 1, 417.

14. L. Wang, X. Feng, L. Ren, Q. Piao, J. Zhong, Y. Wang, H. Li, Y. Chen and B. Wang, J. Am. Chem. Soc., 2015, 137, 4920-4923.

15. E. Senokos, V. Reguero, L. Cabana, J. Palma, R. Marcilla and J. J. Vilatela, $A d v$. Mater. Techn., 2017, 2, 1600290.

16. B. Zhang, R. Tan, L. Yang, J. Zheng, K. Zhang, S. Mo, Z. Lin and F. Pan, Energy Storage Mater, 2018, 10, 139-159.

17. X. Chi, Y. Liang, F. Hao, Y. Zhang, J. Whiteley, H. Dong, P. Hu, S. Lee and Y. Yao, Angew. Chem., 2018, 57, 2630-2634.

18. W. Zhou, Y. Li, S. Xin and J. B. Goodenough, ACS Central Sci., 2017, 3, 52-57.

19. D. Y. Oh, Y. J. Nam, K. H. Park, S. H. Jung, K. T. Kim, A. R. Ha and Y. S. Jung, Adv. Energy Mater., 2019, 9, 1802927.

20. Y. Sun, Y. Y. Wang, G. Li, S. Liu and X. P. Gao, ACS Appl. Mater. Interfaces, 2019, 11, 14830-14839.

21. Q. Zhao, X. Liu, S. Stalin, K. Khan and L. A. Archer, Nat. Energy, 2019, 4, 365373.

22. J. Zhang, J. Zhao, L. Yue, Q. Wang, J. Chai, Z. Liu, X. Zhou, H. Li, Y. Guo, G. Cui and L. Chen, Adv. Energy Mater., 2015, 5, 1501082.

23. P. Zhu, C. Yan, M. Dirican, J. Zhu, J. Zang, R. K. Selvan, C. C. Chung, H. Jia, Y. Li, Y. Kiyak, N. Wu and X. Zhang, J. Mater. Chem. A, 2018, 6, 4279-4285.

24. S. Wu, J. Yi, K. Zhu, S. Bai, Y. Liu, Y. Qiao, M. Ishida and H. Zhou, Adv. Energy 
Mater., 2017, 7, 1601759.

25. A. Perea, M. Dontigny and K. Zaghib, J. Power Sources, 2017, 359, 182-185.

26. X. Xu, S. Wang, H. Wang, B. Xu, C. Hu, Y. Jin, J. Liu and H. Yan, J. Energy Storage, 2017, 13, 387-400.

27. K. Takada, Acta Mater., 2013, 61, 759-770.

28. W. Xu, J. Wang, F. Ding, X. Chen, E. Nasybulin, Y. Zhang and J. G. Zhang, Energy Environ. Sci., 2014, 7, 513-537.

29. Q. Wang, J. Jin, X. Wu, G. Ma, J. Yang and Z. Wen, Phys. Chem. Chem. Phys., 2014, 16, 21225-21229.

30. F. Han, J. Yue, X. Zhu and C. Wang, Adv. Energy Mater, 2018, 8, 1703644.

31. J. Fu, P. Yu, N. Zhang, G. Ren, S. Zheng, W. Huang, X. Long, H. Li and X. Liu, Energy Environ. Sci., 2019, 12, 1404-1412.

32. B. C. Yu, K. Park, J. H. Jang and J. B. Goodenough, ACS Energy Lett., 2016, 1, 633-637.

33. Q. Lu, Y. B. He, Q. Yu, B. Li, Y. V. Kaneti, Y. Yao, F. Kang and Q. H. Yang, $A d v$. Mater., 2017, 29, 1604460.

34. D. Li, L. Chen, T. Wang and L. Z. Fan, ACS Appl. Mater. Interfaces, 2018, 10, 7069-7078.

35. J. A. Lewis, J. Tippens, F. J. Q. Cortes and M. T. McDowell, Trends in Chemistry, 2019, 1, 845-857.

36. R. Sudo, Y. Nakata, K. Ishiguro, M. Matsui, A. Hirano, Y. Takeda, O. Yamamoto and N. Imanishi, Solid State Ionics, 2014, 262, 151-154.

37. D. P. Dubal, N. R. Chodankar, D. H. Kim and P. Gomez-Romero, Chem. Soc. Rev., 2018, 47, 2065-2129.

38. N. Zhao, F. Wu, Y. Xing, W. Qu, N. Chen, Y. Shang, M. Yan, Y. Li, L. Li and R. Chen, ACS Appl. Mater. Interfaces, 2019, 11, 15537-15542.

39. C. Shu, J. Long, S. X. Dou and J. Wang, Small, 2019, 15, e1804701.

40. H. Li, C. Han, Y. Huang, Y. Huang, M. Zhu, Z. Pei, Q. Xue, Z. Wang, Z. Liu, Z. Tang, Y. Wang, F. Kang, B. Li and C. Zhi, Energy Environ. Sci., 2018, 11, 941951.

41. J. Park, M. Park, G. Nam, J. S. Lee and J. Cho, Adv. Mater., 2015, 27, 13961401.

42. S. Chen, L. Ma, K. Zhang, M. Kamruzzaman, C. Zhi and J. A. Zapien, J. Mater. Chem. A, 2019, 7, 7784-7790.

43. Z. Liu, H. Li, M. Zhu, Y. Huang, Z. Tang, Z. Pei, Z. Wang, Z. Shi, J. Liu, Y. Huang and C. Zhi, Nano Energy, 2018, 44, 164-173.

44. N. A. Kyeremateng, T. Brousse and D. Pech, Nat. Nanotech., 2017, 12, 7-15.

45. M. R. Lukatskaya, B. Dunn and Y. Gogotsi, Nat. Commun., 2016, 7, 12647.

46. X. Xu, Z. Hao, H. Wang, J. Liu and H. Yan, Mater. Lett., 2017, 197, 209-212.

47. X. Xu, S. Deng, H. Wang, J. Liu and H. Yan, Nano-Micro Lett., 2017, 9, 22.

48. X. Xu, H. Wang, J. Liu and H. Yan, J. Mater. Sci.-Mater. Electron., 2017, 28, $7532-7543$.

49. D. Aurbach, B. D. McCloskey, L. F. Nazar and P. G. Bruce, Nat. Energy, 2016, 1, 16128 . 
50. X. B. Cheng, R. Zhang, C. Z. Zhao, F. Wei, J. G. Zhang and Q. Zhang, Adv. Sci. 2016, 3, 1500213.

51. X. Zhang, X. Xu, W. He, G. Yang, J. Shen, J. Liu and Q. Liu, J. Mater. Chem. $A, 2015,3,22247-22257$.

52. X. Xu, Z. Hao, H. Wang, C. Hu, J. Liu and Y. Jin, Ionics, 2018, 25, 89-98.

53. Y. Shi, L. Peng, Y. Ding, Y. Zhao and G. Yu, Chem. Soc. Rev., 2015, 44, 66846696.

54. X. Lin, M. Salari, L. M. R. Arava, P. M. Ajayan and M. W. Grinstaff, Chem. Soc. Rev., 2016, 45, 5848-5887.

55. T. M. Gür, Energy Environ. Sci., 2018, 11, 2696-2767.

56. X. Xu, S. Wang, H. Wang, C. Hu, Y. Jin, J. Liu and H. Yan, J. Energy Chemistry, 2018, 27, 513-527.

57. W. Li, J. Liu and D. Zhao, Nat. Rev. Mater, 2016, 1, 16023.

58. J. Liu, J. Wang, C. Xu, H. Jiang, C. Li, L. Zhang, J. Lin and Z. X. Shen, Adv. Sci., 2018, 5, 1700322.

59. H. Duan, Y. X. Yin, X. X. Zeng, J. Y. Li, J. L. Shi, Y. Shi, R. Wen, Y. G. Guo and L. J. Wan, Energy Storage Mater., 2018, 10, 85-91.

60. L. P. Wang, X. D. Zhang, T. S. Wang, Y. X. Yin, J. L. Shi, C. R. Wang and Y. G. Guo, Adv. Energy Mater., 2018, 8, 1801528.

61. T. Liu, Y. Ren, Y. Shen, S. X. Zhao, Y. Lin and C. W. Nan, J. Power Sources, 2016, 324, 349-357.

62. J. Awaka, N. Kijima, H. Hayakawa and J. Akimoto, J. Solid State Chem., 2009, 182, 2046-2052.

63. S. P. Kammampata, R. H. Basappa, T. Ito, H. Yamada and V. Thangadurai, ACS Appl. Energy Mater., 2019, 2, 1765-1773.

64. Y. Shao, H. Wang, Z. Gong, D. Wang, B. Zheng, J. Zhu, Y. Lu, Y. S. Hu, X. Guo, H. Li, X. Huang, Y. Yang, C. W. Nan and L. Chen, ACS Energy Lett., 2018, 3, 1212-1218.

65. R. Murugan, S. Ramakumar and N. Janani, Electrochem. Commun., 2011, 13, 1373-1375.

66. C. Deviannapoorani, L. Dhivya, S. Ramakumar and R. Murugan, J. Power Sources, 2013, 240, 18-25.

67. C. Bernuy-Lopez, W. Manalastas, J. M. Lopez del Amo, A. Aguadero, F. Aguesse and J. A. Kilner, Chem. Mater., 2014, 26, 3610-3617.

68. S. Li, J. Zhu, Y. Wang, J. W. Howard, X. Lü, Y. Li, R. S. Kumar, L. Wang, L. L. Daemen and Y. Zhao, Solid State Ionics, 2016, 284, 14-19.

69. Z. Hu, J. Sheng, J. Chen, G. Sheng, Y. Li, X. Z. Fu, L. Wang, R. Sun and C. P. Wong, New J. Chem., 2018, 42, 9074-9079.

70. Y. Li, H. Xu, P. H. Chien, N. Wu, S. Xin, L. Xue, K. Park, Y. Y. Hu and J. B. Goodenough, Angew. Chem., 2018, 57, 8587-8591.

71. Y. Inaguma and M. Nakashima, J. Power Sources, 2013, 228, 250-255.

72. Y. Zhao and L. L. Daemen, J. Am. Chem. Soc., 2012, 134, 15042-15047.

73. M. Amores, P. J. Baker, E. J. Cussen and S. A. Corr, Chem. Commun., 2018, 54, 10040-10043. 
74. Y. Zhao, Z. Liu, J. Xu, T. Zhang, F. Zhang and X. Zhang, J. Alloy. Compd., 2019, 783, 219-225.

75. K. Kanazawa, S. Yubuchi, C. Hotehama, M. Otoyama, S. Shimono, H. Ishibashi, Y. Kubota, A. Sakuda, A. Hayashi and M. Tatsumisago, Inorg. Chem., 2018, 57, 9925-9930.

76. M. Zhu, Y. Pang, F. Lu, X. Shi, J. Yang and S. Zheng, ACS Appl. Mater. Interfaces, 2019, 11, 14136-14141.

77. Z. Zhang, L. Zhang, Y. Liu, C. Yu, X. Yan, B. Xu and L. M. Wang, J. Alloy. Compd, 2018, 747, 227-235.

78. L. Zhou, K. H. Park, X. Sun, F. Lalère, T. Adermann, P. Hartmann and L. F. Nazar, ACS Energy Lett., 2018, 4, 265-270.

79. C. Yu, S. Ganapathy, J. Hageman, L. van Eijck, E. R. H. van Eck, L. Zhang, T. Schwietert, S. Basak, E. M. Kelder and M. Wagemaker, ACS Appl. Mater. Interfaces, 2018, 10, 33296-33306.

80. N. Kamaya, K. Homma, Y. Yamakawa, M. Hirayama, R. Kanno, M. Yonemura, T. Kamiyama, Y. Kato, S. Hama, K. Kawamoto and A. Mitsui, Nat. Mater., 2011, 10, 682-686.

81. M. A. Kraft, S. Ohno, T. Zinkevich, R. Koerver, S. P. Culver, T. Fuchs, A. Senyshyn, S. Indris, B. J. Morgan and W. G. Zeier, J. Am. Chem. Soc., 2018, 140, 16330-16339.

82. Z. Zhang, E. Ramos, F. Lalère, A. Assoud, K. Kaup, P. Hartman and L. F. Nazar, Energy Environ. Sci., 2018, 11, 87-93.

83. E. P. Ramos, Z. Zhang, A. Assoud, K. Kaup, F. Lalère and L. F. Nazar, Chem. Mater., 2018, 30, 7413-7417.

84. Z. Yu, S. L. Shang, Y. Gao, D. Wang, X. Li, Z. K. Liu and D. Wang, Nano Energy, 2018, 47, 325-330.

85. M. S . M. Duchardt, U. Ruschewitz, S. Adams, S. Dehnen and B. Roling, Angew. Chem. 2018, 57, 1351-1355.

86. Y. Liang, C. Peng, Y. Kamiike, K. Kuroda and M. Okido, J. Alloy. Compd., 2019, 775, 1147-1155.

87. V. Ramar, S. Kumar, S. R. Sivakkumar and P. Balaya, Electrochim. Acta, 2018, 271, 120-126.

88. E. J. Yi, K. Y. Yoon, H. A. Jung, T. Nakayama, M. J. Ji and H. Hwang, Appl. Surf. Sci., 2019, 473, 622-626.

89. B. Yan, L. Kang, M. Kotobuki, F. Wang, X. Huang, X. Song and K. Jiang, Mater. Techn., 2018, 34, 356-360.

90. Y. Tan, H. Wang, P. Liu, Y. Shen, C. Cheng, A. Hirata, T. Fujita, Z. Tang and M. Chen, Energy Environ. Sci., 2016, 9, 2257-2261.

91. M. Pérez-Estébanez, J. Isasi-Marín, D. M. Többens, A. Rivera-Calzada and C. León, Solid State Ionics, 2014, 266, 1-8.

92. Y. Deng, C. Eames, L. H. B. Nguyen, O. Pecher, K. J. Griffith, M. Courty, B. Fleutot, J.-N. Chotard, C. P. Grey, M. S. Islam and C. Masquelier, Chem. Materi., 2018, 30, 2618-2630.

93. Y. Li, Z. Deng, J. Peng, E. Chen, Y. Yu, X. Li, J. Luo, Y. Huang, J. Zhu, C. Fang, 
Q. Li, J. Han and Y. Huang, Chem., 2018, 24, 1057-1061.

94. Z. Zhang, Q. Zhang, J. Shi, Y. S. Chu, X. Yu, K. Xu, M. Ge, H. Yan, W. Li, L. $\mathrm{Gu}$, Y. S. Hu, H. Li, X. Q. Yang, L. Chen and X. Huang, Adv. Energy Mater., 2017, 7, 1601196.

95. P. Kehne, C. Guhl, Q. Ma, F. Tietz, L. Alff, R. Hausbrand and P. Komissinskiy, J. Power Sources, 2019, 409, 86-93.

96. A. A. Łatoszyńska, G. Z. Żukowska, I. A. Rutkowska, P. L. Taberna, P. Simon, P. J. Kulesza and W. Wieczorek, J. Power Sources, 2015, 274, 1147-1154.

97. G. P. Pandey, T. Liu, C. Hancock, Y. Li, X. S. Sun and J. Li, J. Power Sources, 2016, 328, 510-519.

98. N. R. Chodankar, D. P. Dubal, G. S. Gund and C. D. Lokhande, J. Energy Chemistry, 2016, 25, 463-471.

99. X. Peng, H. Liu, Q. Yin, J. Wu, P. Chen, G. Zhang, G. Liu, C. Wu and Y. Xie, Nat. Commun., 2016, 7, 11782.

100. Y. Cui, X. Liang, J. Chai, Z. Cui, Q. Wang, W. He, X. Liu, Z. Liu, G. Cui and J. Feng, Adv. Sci., 2017, 4, 1700174.

101. J. Chai, Z. Liu, J. Ma, J. Wang, X. Liu, H. Liu, J. Zhang, G. Cui and L. Chen, Adv. Sci., 2017, 4, 1600377.

102. H. Feng, C. Ma, K. Dai, G. Kuang, D. G. Ivey and W. Wei, ChemElectroChem, 2019, 6, 904-910.

103. X. X. Zeng, Y. X. Yin, N. W. Li, W. C. Du, Y. G. Guo and L. J. Wan, J. Am. Chem. Soc., 2016, 138, 15825-15828.

104. A. Nag, M. A. Ali, A. Singh, R. Vedarajan, N. Matsumi and T. Kaneko, J. Mater. Chem. A, 2019, 7, 4459-4468.

105. H. Gao, W. Zhou, K. Park and J. B. Goodenough, Adv. Energy Mater., 2016, 6, 1600467.

106. P. Dhatarwal and R. J. Sengwa, Polym. Bull., 2018, 75, 5645-5666.

107. P. Dhatarwal and R. J. Sengwa, J. Polym. Res., 2017, 24, 135.

108. R. Rathika, O. Padmaraj and S. A. Suthanthiraraj, Ionics, 2017, 24, 243-255.

109. Y. Lim, H. A. Jung and H. Hwang, Energies, 2018, 11, 2559.

110. L. Li, F. Wang, J. Li, X. Yang and J. You, Int. J. Hydrogen Energy, 2017, 42, 12087-12093.

111. Y. Ma, L. B. Li, G. X. Gao, X. Y. Yang and Y. You, Electrochim. Acta, 2016, 187, 535-542.

112. S. Suriyakumar, S. Gopi, M. Kathiresan, S. Bose, E. B. Gowd, J. R. Nair, N. Angulakshmi, G. Meligrana, F. Bella, C. Gerbaldi and A. M. Stephan, Electrochim. Acta, 2018, 285, 355-364.

113. Y. L. Yap, A. H. You and L. L. Teo, Ionics, 2019, 25, 3087-3098.

114. J. Shi, H. Xiong, Y. Yang and H. Shao, Solid State Ionics, 2018, 326, 136-144.

115. M. Johnsi and S. Austin Suthanthiraraj, Ionics, 2016, 22, 1075-1083.

116. Y. Zhao, C. Wu, G. Peng, X. Chen, X. Yao, Y. Bai, F. Wu, S. Chen and X. Xu, J. Power Sources, 2016, 301, 47-53.

117. L. Chen, Y. Li, S. P. Li, L. Z. Fan, C. W. Nan and J. B. Goodenough, Nano Energy, 2018, 46, 176-184. 
118. H. Huo, Y. Chen, J. Luo, X. Yang, X. Guo and X. Sun, Adv. Energy Mater, 2019, 9, 1804004.

119. X. Wang, H. Zhai, B. Qie, Q. Cheng, A. Li, J. Borovilas, B. Xu, C. Shi, T. Jin, X. Liao, Y. Li, X. He, S. Du, Y. Fu, M. Dontigny, K. Zaghib and Y. Yang, Nano Energy, 2019, 60, 205-212.

120. S. Song, Y. Wu, W. Tang, F. Deng, J. Yao, Z. Liu, R. Hu, Alamusi, Z. Wen, L. Lu and N. Hu, ACS Sustain. Chem. Eng., 2019, 7, 7163-7170.

121. Y. F. Liang, S. J. Deng, Y. Xia, X. L. Wang, X. H. Xia, J. B. Wu, C. D. Gu and J. P. Tu, Mater. Res. Bull., 2018, 102, 412-417.

122. J. Zhang, C. Zheng, J. Lou, Y. Xia, C. Liang, H. Huang, Y. Gan, X. Tao and W. Zhang, J. Power Sources, 2019, 412, 78-85.

123. Z. Wan, D. Lei, W. Yang, C. Liu, K. Shi, X. Hao, L. Shen, W. Lv, B. Li, Q. H. Yang, F. Kang and Y. B. He, Adv. Funct. Mater., 2019, 29, 1805301.

124. M. Wu, B. Xu and C. Ouyang, Chin. Phys. B, 2016, 25, 018206.

125. M. Park, X. Zhang, M. Chung, G. B. Less and A. M. Sastry, J. Power Sources, 2010, 195, 7904-7929.

126. Z. Gao, H. Sun, L. Fu, F. Ye, Y. Zhang, W. Luo and Y. Huang, Adv. Mater, 2018, 30, e1705702.

127. Y. Kato, S. Hori, T. Saito, K. Suzuki, M. Hirayama, A. Mitsui, M. Yonemura, H. Iba and R. Kanno, Nat. Energy, 2016, 1, 16030.

128. J. Janek and W. G. Zeier, Nat. Energy, 2016, 1, 16141.

129. X. Han, Y. Gong, K. K. Fu, X. He, G. T. Hitz, J. Dai, A. Pearse, B. Liu, H. Wang, G. Rubloff, Y. Mo, V. Thangadurai, E. D. Wachsman and L. Hu, Nat. Mater., 2017, 16, 572-579.

130. Y. J. Nam, S. J. Cho, D. Y. Oh, J. M. Lim, S. Y. Kim, J. H. Song, Y. G. Lee, S. Y. Lee and Y. S. Jung, Nano Lett., 2015, 15, 3317-3323.

131. Q. Liu, Z. Geng, C. Han, Y. Fu, S. Li, Y. B. He, F. Kang and B. Li, J. Power Sources, 2018, 389, 120-134.

132. Y. Zhu, J. G. Connell, S. Tepavcevic, P. Zapol, R. Garcia-Mendez, N. J. Taylor, J. Sakamoto, B. J. Ingram, L. A. Curtiss, J. W. Freeland, D. D. Fong and N. M. Markovic, Adv. Energy Mater., 2019, 9, 1803440.

133. J. Dai, C. Yang, C. Wang, G. Pastel and L. Hu, Adv. Mater., 2018, 30, e1802068..

134. H. Xu, Y. Li, A. Zhou, N. Wu, S. Xin, Z. Li and J. B. Goodenough, Nano Lett., 2018, 18, 7414-7418.

135. M. He, Z. Cui, C. Chen, Y. Li and X. Guo, J. Mater. Chem. A, 2018, 6, $11463-$ 11470.

136. T. Krauskopf, H. Hartmann, W. G. Zeier and J. Janek, ACS Appl. Mater. Interfaces, 2019, 11, 14463-14477.

137. R. Pfenninger, S. Afyon, I. Garbayo, M. Struzik and J. L. M. Rupp, Adv. Funct. Mater., 2018, 28, 1800879.

138. I. Garbayo, M. Struzik, W. J. Bowman, R. Pfenninger, E. Stilp and J. L. M. Rupp, Adv. Energy Mater., 2018, 8, 1702265.

139. R. H. Brugge, A. K. O. Hekselman, A. Cavallaro, F. M. Pesci, R. J. Chater, J. A. Kilner and A. Aguadero, Chem. Mater., 2018, 30, 3704-3713. 
140. Z. Jiang, H. Xie, S. Wang, X. Song, X. Yao and H. Wang, Adv. Energy Mater, 2018, 8, 1801433.

141. H. T. T. Le, D. T. Ngo, P. N. Didwal, J. G. Fisher, C. N. Park, I. D. Kim and C. J. Park, J. Mater. Chem. A, 2019, 7, 3150-3160.

142. H. S. Shin, W. G. Ryu, M. S. Park, K. N. Jung, H. Kim and J. W. Lee, ChemSusChem, 2018, 11, 3184-3190.

143. J. Wu, X. Li, Y. Zhao, L. Liu, W. Qu, R. Luo, R. Chen, Y. Li and Q. Chen, J. Mater. Chem. A, 2018, 6, 20896-20903.

144. Y. Sun, Y. Wang, X. Liang, Y. Xia, L. Peng, H. Jia, H. Li, L. Bai, J. Feng, H. Jiang and J. Xie, J. Am. Chem. Soc., 2019, 141, 5640-5644.

145. J. A. Dawson, T. S. Attari, H. Chen, S. P. Emge, K. E. Johnston and M. S. Islam, Energy Environ. Sci., 2018, 11, 2993-3002.

146. Z. Wang, H. Xu, M. Xuan and G. Shao, J. Mater. Chem. A, 2018, 6, 73-83.

147. J. A. Dawson, H. Chen and M. S. Islam, J. Phys. Chem. C, 2018, 122, 2397823984.

148. B. Chen, C. Xu and J. Zhou, J. Electrochem. Soc., 2018, 165, A3946-A3951.

149. I. S. Klein, Z. Zhao, S. K. Davidowski, J. L. Yarger and C. A. Angell, $A d v$. Energy Mater., 2018, 8, 1801324.

150. Q. Ge, L. Zhou, Y.-m. Lian, X. Zhang, R. Chen and W. Yang, Electrochem. Commun., 2018, 97, 100-104.

151. D. Chang, K. Oh, S. J. Kim and K. Kang, Chem. Mater., 2018, 30, 8764-8770.

152. K. Kaup, F. Lalère, A. Huq, A. Shyamsunder, T. Adermann, P. Hartmann and L. F. Nazar, Chem. Mater., 2018, 30, 592-596.

153. C. Vinado, S. Wang, Y. He, X. Xiao, Y. Li, C. Wang and J. Yang, J. Power Sources, 2018, 396, 824-830.

154 Y. Wang, D. Lu, M. Bowden, P. Z. El Khoury, K. S. Han, Z. D. Deng, J. Xiao, J.-G. Zhang and J. Liu, Chem. Mater., 2018, 30, 990-997.

155. N. J. J. de Klerk, E. van der Maas and M. Wagemaker, ACS Appl. Energy Mater, 2018, 1, 3230-3242.

156. Z. Liu, W. Fu, E. A. Payzant, X. Yu, Z. Wu, N. J. Dudney, J. Kiggans, K. Hong, A. J. Rondinone and C. Liang, J. Am. Chem. Soc., 2013, 135, 975-978.

157. E. Rangasamy, Z. Liu, M. Gobet, K. Pilar, G. Sahu, W. Zhou, H. Wu, S. Greenbaum and C. Liang, J. Am. Chem. Soc., 2015, 137, 1384-1387.

158. K. H. Park, D. Y. Oh, Y. E. Choi, Y. J. Nam, L. Han, J. Y. Kim, H. Xin, F. Lin, S. M. Oh and Y. S. Jung, Adv. Mater., 2016, 28, 1874-1883..

159. A. Banerjee, K. H. Park, J. W. Heo, Y. J. Nam, C. K. Moon, S. M. Oh, S. T. Hong and Y. S. Jung, Angew. Chem., 2016, 55, 9634-9638.

160. X. Yao, D. Liu, C. Wang, P. Long, G. Peng, Y. S. Hu, H. Li, L. Chen and X. Xu, Nano Lett., 2016, 16, 7148-7154.

161. T. A. Yersak, H. A. Macpherson, S. C. Kim, V.-D. Le, C. S. Kang, S. B. Son, Y. H. Kim, J. E. Trevey, K. H. Oh, C. Stoldt and S. H. Lee, Adv. Energy Mater., 2013, 3, 120-127.

162. Y. Liu, C. Li, B. Li, H. Song, Z. Cheng, M. Chen, P. He and H. Zhou, Adv. Energy Mater, 2018, 8, 1702374. 
163. Q. Ma, C. L. Tsai, X. K. Wei, M. Heggen, F. Tietz and J. T. S. Irvine, J. Mater. Chem. A, 2019, 7, 7766-7776.

164. C. K. Moon, H. J. Lee, K. H. Park, H. Kwak, J. W. Heo, K. Choi, H. Yang, M. S. Kim, S. T. Hong, J. H. Lee and Y. S. Jung, ACS Energy Lett., 2018, 3, 25042512 .

165. H. Jia, Y. Sun, Z. Zhang, L. Peng, T. An and J. Xie, Energy Storage Mater. 2019, 23, 508-513.

166. L. Hallopeau, D. Bregiroux, G. Rousse, D. Portehault, P. Stevens, G. Toussaint and C. Laberty-Robert, J. Power Sources, 2018, 378, 48-52.

167. J. Wang, C. W. Sun, Y. D. Gong, H. R. Zhang, J. A. Alonso, M. T. FernándezDíaz, Z. L. Wang and J. B. Goodenough, Chin. Phys. B, 2018, 27, 128201.

168. C. de la Torre-Gamarra, G. B. Appetecchi, U. Ulissi, A. Varzi, A. Varez and S. Passerini, J. Power Sources, 2018, 383, 157-163.

169. G. Liao, T. Mahrholz, S. Geier, P. Wierach and M. Wiedemann, J. Solid State Electrochem., 2017, 22, 1055-1061.

170. X. Cheng, J. Pan, Y. Zhao, M. Liao and H. Peng, Adv. Energy Mater., 2018, 8, 1702184.

171. Y. Shi and G. Yu, Chem. Mater., 2016, 28, 2466-2477.

172. G. K. Veerasubramani, K. Krishnamoorthy, P. Pazhamalai and S. J. Kim, Carbon, 2016, 105, 638-648.

173. C. Y. Su, H. Cheng, W. Li, Z. Q. Liu, N. Li, Z. Hou, F. Q. Bai, H. X. Zhang and T. Y. Ma, Adv. Energy Mater., 2017, 7, 1602420.

174. W. B. Luo, S. L. Chou, J. Z. Wang, Y. M. Kang, Y. C. Zhai and H. K. Liu, Chem. Commun., 2015, 51, 8269-8272.

175. N. R. Chodankar, D. P. Dubal, A. C. Lokhande and C. D. Lokhande, J. Colloid Interf. Sci., 2015, 460, 370-376.

176. Y. Xia, X. Wang, X. Xia, R. Xu, S. Zhang, J. Wu, Y. Liang, C. Gu and J. Tu, Chem., 2017, 23, 15203-15209.

177. W. Zhang, J. Nie, F. Li, Z. L. Wang and C. Sun, Nano Energy, 2018, 45, 413419.

178. J. K. Kim, Y. J. Lim, H. Kim, G. B. Cho and Y. Kim, Energy Environ. Sci., 2015, 8, 3589-3596.

179. J. Zhang, N. Zhao, M. Zhang, Y. Li, P. K. Chu, X. Guo, Z. Di, X. Wang and H. Li, Nano Energy, 2016, 28, 447-454.

180. Y. Zhao, Z. Huang, S. Chen, B. Chen, J. Yang, Q. Zhang, F. Ding, Y. Chen and X. Xu, Solid State Ionics, 2016, 295, 65-71.

181. J. Wan, J. Xie, X. Kong, Z. Liu, K. Liu, F. Shi, A. Pei, H. Chen, W. Chen, J. Chen, X. Zhang, L. Zong, J. Wang, L. Q. Chen, J. Qin and Y. Cui, Nat. Nanotechnol., 2019, 14, 705-711.

182. P. Raghavan, J. Manuel, X. Zhao, D.-S. Kim, J.-H. Ahn and C. Nah, J. Power Sources, 2011, 196, 6742-6749.

183. K. Jeddi, M. Ghaznavi and P. Chen, J. Mater. Chem. A, 2013, 1, 2769-2772.

184. R. He and T. Kyu, Macromolecules, 2016, 49, 5637-5648.

185. O. Borodin and G. D. Smith, Macromolecules, 2006, 39, 1620-1629. 
186. Q. Zhao, P. Chen, S. Li, X. Liu and L. A. Archer, J. Mater. Chem. A, 2019, 7, 7823-7830.

187. S. B. Aziz, T. J. Woo, M. F. Z. Kadir and H. M. Ahmed, J. Sci.-Adv. Mater. Dev, 2018, 3, 1-17.

188. X. B. Cheng, C. Z. Zhao, Y. X. Yao, H. Liu and Q. Zhang, Chem., 2019, 5, 7496

189. F. Zheng, M. Kotobuki, S. Song, M. O. Lai and L. Lu, J. Power Sources, 2018, 389, 198-213.

190. W. Zhou, Z. Wang, Y. Pu, Y. Li, S. Xin, X. Li, J. Chen and J. B. Goodenough, Adv. Mater., 2019, 31, e1805574.

191. E. Umeshbabu, B. Zheng and Y. Yang, Electrochem. Energy Rev., 2019, 2, 199230.

192. J. Cao, L. Wang, X. He, M. Fang, J. Gao, J. Li, L. Deng, H. Chen, G. Tian, J. Wang and S. Fan, J. Mater. Chem. A, 2013, 1, 5955-5961.

193. S. Liu, H. Wang, N. Imanishi, T. Zhang, A. Hirano, Y. Takeda, O. Yamamoto and J. Yang, J. Power Sources, 2011, 196, 7681-7686.

194. J. Hassoun and B. Scrosati, Adv. Mater., 2010, 22, 5198-5201.

195. G. G. Eshetu, X. Judez, C. Li, O. Bondarchuk, L. M. Rodriguez-Martinez, H. Zhang and M. Armand, Angew. Chem., 2017, 56, 15368-15372.

196. W. Li, S. Zhang, B. Wang, S. Gu, D. Xu, J. Wang, C. Chen and Z. Wen, ACS Appl. Mater. Interfaces, 2018, 10, 23874-23882.

197. S. Choudhury, R. Mangal, A. Agrawal and L. A. Archer, Nat. Commun., 2015, 6, 10101.

198. B. Kumar, J. Power Sources, 2003, 123, 132-136.

199. M. Marcinek, M. Ciosek, G. Zukowska, W. Wieczorek, K. Jeffrey and J. Stevens, Solid State Ionics, 2005, 176, 367-376.

200. D. Golodnitsky, J. Electrochem. Soc., 1997, 144, 3484-3491.

201. C. Wang, X. W. Zhang and A. J. Appleby, J. Electrochem. Soc., 2005, 152, A205-A209.

202. Y. J. Lim, H. W. Kim, S. S. Lee, H. J. Kim, J. K. Kim, Y. G. Jung and Y. Kim, ChemPlusChem, 2015, 80, 1100-1103.

203. X. Zhang, T. Liu, S. Zhang, X. Huang, B. Xu, Y. Lin, B. Xu, L. Li, C. W. Nan and Y. Shen, J. Am. Chem. Soc., 2017, 139, 13779-13785.

204. X. Tao, Y. Liu, W. Liu, G. Zhou, J. Zhao, D. Lin, C. Zu, O. Sheng, W. Zhang, H. W. Lee and Y. Cui, Nano Lett., 2017, 17, 2967-2972.

205. Y. Xu, Y. Zhao, J. Ren, Y. Zhang and H. Peng, Angew. Chem., 2016, 55, 79797982.

206. J. Bae, Y. Li, J. Zhang, X. Zhou, F. Zhao, Y. Shi, J. B. Goodenough and G. Yu, Angew. Chem., 2018, 57, 2096-2100.

207. S. Yu, S. Schmohl, Z. Liu, M. Hoffmeyer, N. Schön, F. Hausen, H. Tempel, H. Kungl, H. D. Wiemhöfer and R. A. Eichel, J. Mater. Chem. A, 2019, 7, 38823894.

208. A. Martínez-Juárez, C. Pecharromán, J. E. Iglesias and J. M. Rojo, J. Phys. Chem. B, 1998, 102, 372-375. 
209. Y. Seino, T. Ota, K. Takada, A. Hayashi and M. Tatsumisago, Energy Environ. Sci., 2014, 7, 627-631.

210. Z. Tu, S. Choudhury, M. J. Zachman, S. Wei, K. Zhang, L. F. Kourkoutis and L. A. Archer, Nat. Energy, 2018, 3, 310-316.

211. R. C. Xu, X. L. Wang, S. Z. Zhang, Y. Xia, X. H. Xia, J. B. Wu and J. P. Tu, J. Power Sources, 2018, 374, 107-112.

212. Z. Zhang, S. Chen, J. Yang, J. Wang, L. Yao, X. Yao, P. Cui and X. Xu, ACS Appl. Mater. Interfaces, 2018, 10, 2556-2565..

213. P. Hu, Y. Zhang, X. Chi, K. Kumar Rao, F. Hao, H. Dong, F. Guo, Y. Ren, L. C. Grabow and Y. Yao, ACS Appl. Mater. Interfaces, 2019, 11, 9672-9678.

214. S. Yubuchi, M. Uematsu, C. Hotehama, A. Sakuda, A. Hayashi and M. Tatsumisago, J. Mater. Chem. A, 2019, 7, 558-566.

215. S. Yubuchi, W. Nakamura, T. Bibienne, S. Rousselot, L. W. Taylor, M. Pasquali, M. Dollé, A. Sakuda, A. Hayashi and M. Tatsumisago, J. Power Sources, 2019, 417, 125-131.

216. C. Zhao, J. Liang, Q. Sun, J. Luo, Y. Liu, X. Lin, Y. Zhao, H. Yadegari, M. N. Banis, R. Li, H. Huang, L. Zhang, R. Yang, S. Lu and X. Sun, Small Methods, 2019, 3, 1800437.

217. P. Liu, X. Weng, Z. Liu, Y. Zhang, Q. Qiu, W. Wang, M. Zhou, W. Cai, M. Ni, M. Liu and J. Liu, ACS Appl. Energy Mater, 2019, 2, 1480-1488.

218. X. Tang, D. Zhou, P. Li, X. Guo, C. Wang, F. Kang, B. Li and G. Wang, $A C S$ Central Sci., 2019, 5, 365-373.

219. S. J. Cho, G. Y. Jung, S. H. Kim, M. Jang, D. K. Yang, S. K. Kwak and S. Y. Lee, Energy Environ. Sci., 2019, 12, 559-565.

220. J. Zhou, X. Li, C. Yang, Y. Li, K. Guo, J. Cheng, D. Yuan, C. Song, J. Lu and B. Wang, Adv. Mater., 2019, 31, e1804439.

221. Y. Zeng, X. Zhang, Y. Meng, M. Yu, J. Yi, Y. Wu, X. Lu and Y. Tong, Adv. Mater., 2017, 29, 1700274.

222. Z. Wang, R. Tan, H. Wang, L. Yang, J. Hu, H. Chen and F. Pan, Adv. Mater, 2018, 30, 1704436.

223. W. Zhou, S. Wang, Y. Li, S. Xin, A. Manthiram and J. B. Goodenough, J. Am. Chem. Soc., 2016, 138, 9385-9388.

224. Z. D. Hood, H. Wang, A. Samuthira Pandian, J. K. Keum and C. Liang, J. Am. Chem. Soc., 2016, 138, 1768-1771.

225. H. Duan, Y. X. Yin, Y. Shi, P. F. Wang, X. D. Zhang, C. P. Yang, J. L. Shi, R. Wen, Y. G. Guo and L. J. Wan, J. Amer. Chem. Soc., 2018, 140, 82-85.

226. X. L. Fan, X. Ji, F. D. Han, J. Yue, J. Chen, L. Chen, T. Deng, J. J. Jiang and C. S. Wang, Sci. Adv., 2018, 4, eaau9245.

227. D. Zhou, M. Liu, Q. Yun, X. Wang, Y. B. He, B. Li, Q. H. Yang, Q. Cai and F. Kang, Small, 2017, 13, 1602015.

228 D. H. Kim, D. Y. Oh, K. H. Park, Y. E. Choi, Y. J. Nam, H. A. Lee, S. M. Lee and Y. S. Jung, Nano Lett., 2017, 17, 3013-3020.

229. M. R. Busche, T. Drossel, T. Leichtweiss, D. A. Weber, M. Falk, M. Schneider, M. L. Reich, H. Sommer, P. Adelhelm and J. Janek, Nat. Chem., 2016, 8, 426- 
434.

230. M. Weiss, B. K. Seidlhofer, M. Geiss, C. Geis, M. R. Busche, M. Becker, N. M. Vargas-Barbosa, L. Silvi, W. G. Zeier, D. Schroder and J. Janek, ACS Appl. Mater. Interfaces, 2019, 11, 9539-9547.

231. B. Lei, G. R. Li, P. Chen and X. P. Gao, ACS Appl. Energy Mater., 2019, 2, 1000-1005.

232. J. Yang, Z. Pan, Q. Yu, Q. Zhang, X. Ding, X. Shi, Y. Qiu, K. Zhang, J. Wang and Y. Zhang, ACS Appl. Mater. Interfaces, 2019, 11, 5938-5946.

233. F. Liang, X. Qiu, Q. Zhang, Y. Kang, A. Koo, K. Hayashi, K. Chen, D. Xue, K. N. Hui, H. Yadegari and X. Sun, Nano Energy, 2018, 49, 574-579.

234. S. Liu, Y. Yin, D. Ni, K. S. Hui, M. Ma, S. Park, K. N. Hui, C. Y. Ouyang and S. C. Jun, Energy Storage Mater, 2019, 22, 384-396.

235. S. Liu, Y. Yin, M. Wu, K. S. Hui, K. N. Hui, C. Y. Ouyang and S. C. Jun, Small, 2019, 15, e1803984.

236. S. Liu, Y. Yin, K. S. Hui, K. N. Hui, S. C. Lee and S. C. Jun, Adv. Sci., 2018, 5, 1800733.

237. S. Wu, C. Liu, D. A. Dinh, K. S. Hui, K. N. Hui, J. M. Yun and K. H. Kim, $A C S$ Sustain. Chem. Eng., 2019, 7, 9763-9770.

238. S. Wu, K. S. Hui and K. N. Hui, Carbon, 2018, 132, 776-784.

239. X. Xu, J. Mi, M. Fan, K. Yang, H. Wang, J. Liu and H. Yan, J. Clean. Prod., 2019, 213, 1080-1086.

240. X. Luo, J. Wang, M. Dooner and J. Clarke, Appl. Energy, 2015, 137, 511-536.

241. M. C. Argyrou, P. Christodoulides and S. A. Kalogirou, Renew. Sust. Energy Rev., 2018, 94, 804-821.

242. Z. Zhang and K. T. Chau, IEEE T. Smart Grid, 2017, 8, 2803-2812.

243. J. Heelan, E. Gratz, Z. Zheng, Q. Wang, M. Chen, D. Apelian and Y. Wang, Jom, 2016, 68, 2632-2638.

244. Z. P. Cano, D. Banham, S. Ye, A. Hintennach, J. Lu, M. Fowler and Z. Chen, Nat. Energy, 2018, 3, 279-289.

245. Y. Bai, B. Shen, S. Zhang, Z. Zhu, S. Sun, J. Gao, B. Li, Y. Wang, R. Zhang and F. Wei, Adv. Mater., 2019, 31, e1800680.

246. N. Cui, J. Liu, L. Gu, S. Bai, X. Chen and Y. Qin, ACS Appl. Mater. Interfaces, 2015, 7, 18225-18230.

247. M. Salauddin, R. M. Toyabur, P. Maharjan and J. Y. Park, Nano Energy, 2018, 45, 236-246.

248. G. Nagaraju, S. C. Sekhar, B. Ramulu, L. K. Bharat, G. S. R. Raju, Y. K. Han and J. S. Yu, Nano Energy, 2018, 50, 448-461.

249. J. Bae, M. K. Song, Y. J. Park, J. M. Kim, M. Liu and Z. L. Wang, Angew. Chem. Int. Ed., 2011, 50, 1683-1687.

250. C. Li, M. M. Islam, J. Moore, J. Sleppy, C. Morrison, K. Konstantinov, S. X. Dou, C. Renduchintala and J. Thomas, Nat. Commun., 2016, 7, 13319.

251. L. Kou, T. Huang, B. Zheng, Y. Han, X. Zhao, K. Gopalsamy, H. Sun and C. Gao, Nat. Commun., 2014, 5, 3754.

252. M. Tebyetekerwa, I. Marriam, Z. Xu, S. Yang, H. Zhang, F. Zabihi, R. Jose, S. 
Peng, M. Zhu and S. Ramakrishna, Energy Environ. Sci., 2019, 12, 2148-2160.

2 